\title{
ph
}

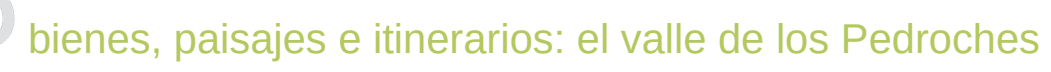

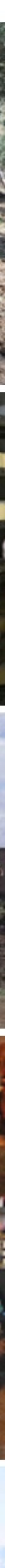

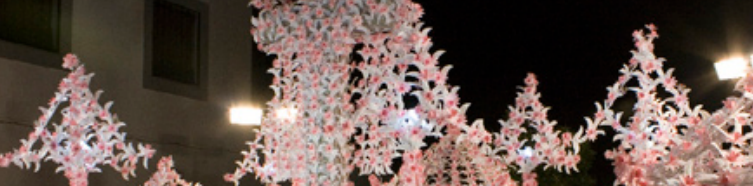

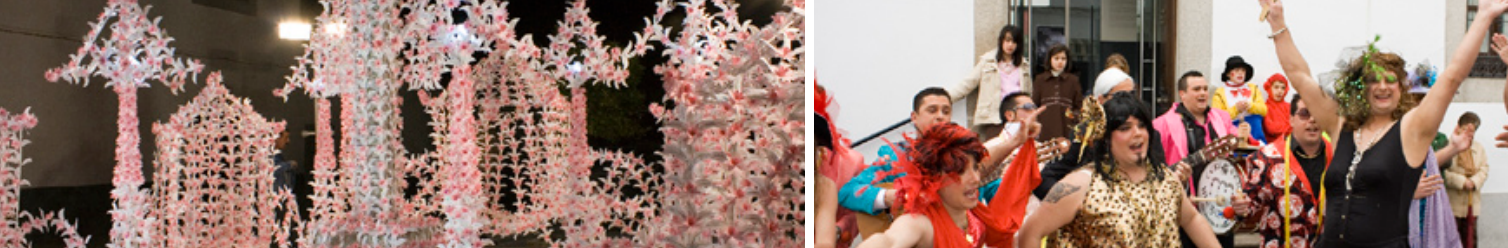
d 

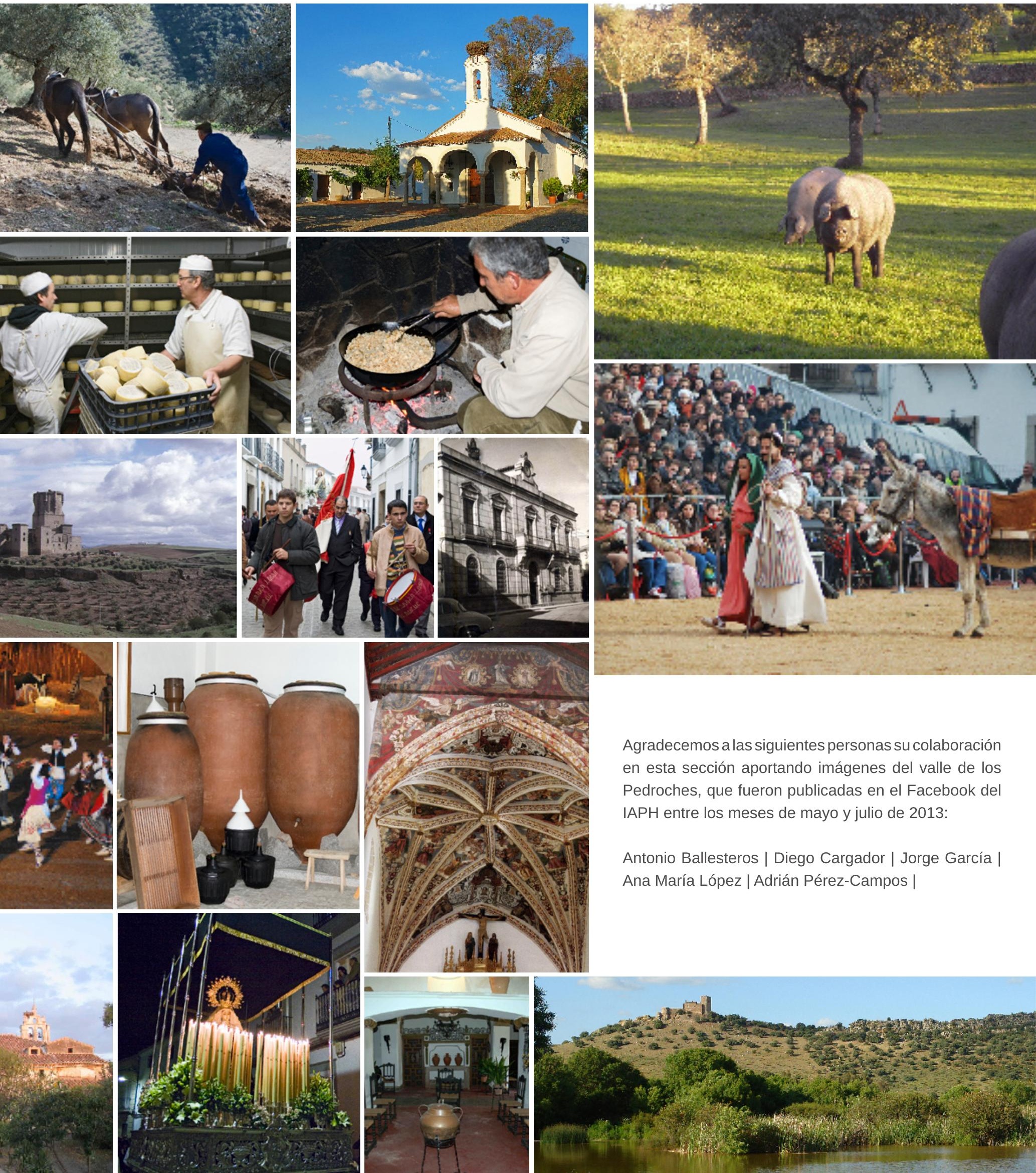

Agradecemos a las siguientes personas su colaboración en esta sección aportando imágenes del valle de los Pedroches, que fueron publicadas en el Facebook del IAPH entre los meses de mayo y julio de 2013:

Antonio Ballesteros | Diego Cargador | Jorge García | Ana María López | Adrián Pérez-Campos | 


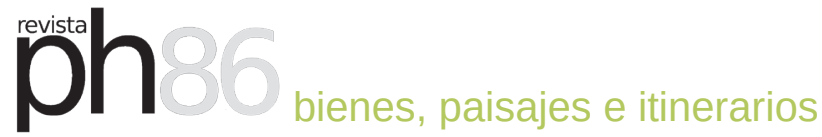

\section{Acerca de los Pedroches}

Elodia Hernández León | Dpto. Antropologia Social, Psicología Básica y Salud Pública, Universidad Pablo de Olavide

URL de la contribución <www.iaph.es/revistaph/index.php/revistaph/article/view/3516>

\section{RESUMEN}

El presente artículo se ha concebido a modo de presentación e introducción del área más al norte de Andalucía, los Pedroches. Se centra para ello en la definición comarcal de esta tierra. Se abordan los rasgos principales que dan sentido a su consideración como un territorio cultural, una comarca consolidada.

Lejos de partir de un enfoque estático, proyectamos una visión dinámica de la delimitación territorial aludiendo a aspectos materiales y simbólicos.

En conclusión, se apuesta por el análisis del contexto comarcal para comprender el patrimonio cultural de la zona.

\section{Palabras clave}

Andalucía | Antropología social | Córdoba (Provincia) | Identidad cultural | Patrimonio cultural | Valle de los Pedroches (Córdoba) | 


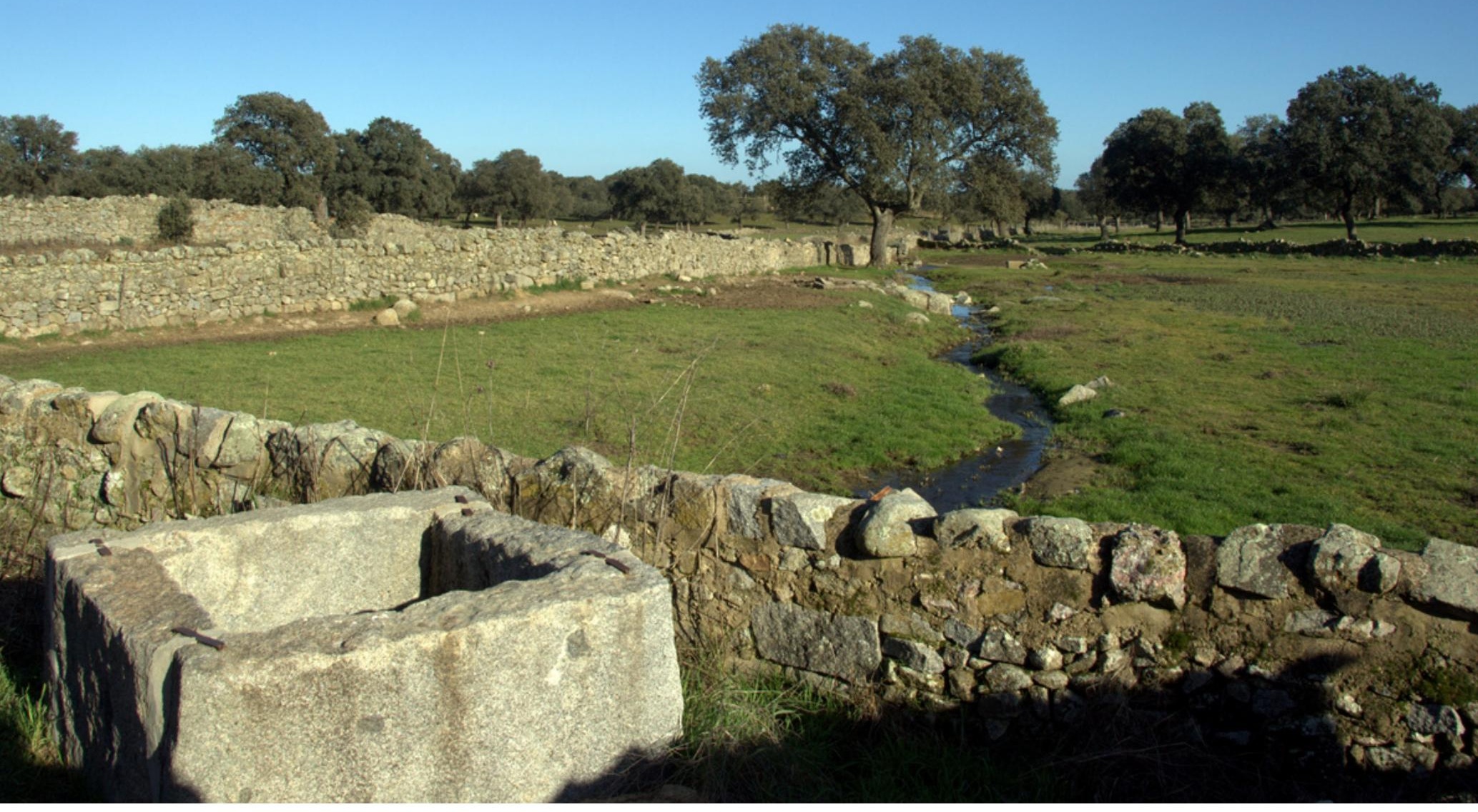

Dehesa del valle de los Pedroches | foto Aniceto Delgado Méndez 
Los Pedroches es una tierra tan singular como desconocida en el contexto andaluz. Presentarla resulta difícil por la gran riqueza histórico-cultural de un espacio lejano y oculto para gran parte de los investigadores, gestores y andaluces en general, que no han tenido la oportunidad de conocer este territorio, más allá de algunas imágenes ligadas a los productos alimentarios de la afamada marca COVAP (que recoge el topónimo en las siglas: Cooperativa del Valle de los Pedroches).

La singularidad que otorgamos a los Pedroches está estrechamente vinculada a nuestra idea de comarca. Está claro que esta sección de Bienes, paisajes e itinerarios no se dedica a un espacio delimitado como parque natural o a un conjunto de municipios unidos por ser objeto de proyectos conjuntos de desarrollo rural (las mancomunidades Leader). Indudablemente, presentar los Pedroches es abordar un territorio cultural que se identifica, e identificamos, como una comarca.

Esta comarca de diecisiete poblaciones y $3.612 \mathrm{~km}^{2}$ es reconocida e identificada en el contexto andaluz. Y ello no carece de importancia si tenemos en cuenta que no existe un mapa comarcal en Andalucía, es decir, que no se ha abordado, y sí olvidado, la división comarcal andaluza más allá de delimitaciones para la implementación de políticas territoriales. Mientras el uso del término comarca en algunas áreas cuyas poblaciones se unen para la gestión de servicios y programas puede ser cuestionado, en el caso de este territorio no.

Los diferentes aspectos del patrimonio cultural, tangibles e intangibles, abordados aquí tienen ese rasgo que los singulariza: el de tomar sentido desde la pertenencia a un territorio comarcal construido históricamente y con plena vigencia en la actualidad. De esta forma, los bienes, paisajes e itinerarios recorridos en las páginas que siguen nos representan a una comarca cultural a través de sus características paisajísticas, de la memoria e historia, de sus modos de vida, de sus rituales tradicionales, de su reconocida ubicación fronteriza...

No se trata de presentar un espacio homogéneo de similares rasgos que justifiquen una definición estática, antes al contrario, la articulación entre las poblaciones de los Pedroches, las relaciones socioeconómicas y políticas, diversas y conflictivas, entre sus habitantes, la capacidad de un centro de atracción, contribuyen a la construcción de un espacio supramunicipal de carácter comarcal (HERNÁNDEZ, 2005).

\section{UN VALLE DE SIERRA QUE NO ES UN VALLE, NI ES UNA SIERRA}

La morfología de los Pedroches es la de una penillanura caracterizada por relieves poco abruptos, una gran faja de terreno, de entre $20-30 \mathrm{Km}$ de ancho, que, desde Belalcázar a Villanueva de Córdoba, atraviesa de noroeste a 
suroeste el norte de la provincia de Córdoba. Está flanqueada por las estribaciones de Sierra Morena al sur y por la sierra de Santa Eufemia al norte, encontrándose la zona más llana en torno a Hinojosa del Duque (AA.VV., 2010: 404).

La identificación de la comarca con un valle, tal como se recoge en la denominación muy extendida de valle de los Pedroches, y de ésta como parte de la mitad serrana de Córdoba, no deja de ser una contradicción con las clasificaciones geográficas.

Es esta una denominación relativamente reciente, generalizada a raíz de una de las primeras interpretaciones integradoras del contexto comarcal como realidad geográfico-cultural plasmada en el pequeño trabajo de A. Gil Muñiz (1926). Hoy se ha consolidado plenamente, pese a que no responde a la definición de un valle, espacio procedente de la acción orográfica de un río. El predominio de lo visual en nuestra noción de paisaje (COSGROVE, 2002), recrea una imagen de "valle" a partir de una extensión llana circundada de cerros. Este baile de términos, desde nuestro punto de vista, está relacionado con una percepción consciente de unidad cultural (AGUDO, 1990) ${ }^{1}$. Sin embargo, esta contradicción conceptual, aún conocida, es irrelevante para el conjunto de la población, puesto que la denominación de valle de los Pedroches se ha impuesto tanto a nivel popular como en ámbitos institucionales, empresas comerciales, o diversidad de páginas web que hacen referencia a este territorio (AGUDO; HERNÁNDEZ, 2010).

Como tampoco es del todo acertada, desde el conocimiento experto, la división en dos mitades de Córdoba, en tanto que se basa en una concepción dual de la provincia que es cuestionable. La mitad serrana recoge a las tres comarcas del norte provincial (la sierra, valle de los Pedroches y cuenca del Guadiato). Es percibida como un territorio montañoso de carácter ganadero y aislado del centro y sur. Mientras que la mitad sur, identificada con la campiña, incluye a las serranías subbéticas.

La inclusión en tierra llana de terrenos más parejos a los serranos, por su orografía y aprovechamiento, es significativa. Las "evidentes" diferencias, con respecto tanto a la orografía como a los sistemas de aprovechamiento, entre campiña y subbéticas no han desencadenado en el imaginario colectivo una imagen desagregada de estos territorios, quedando anexionado este espacio "más serrano" en la imagen más amplia, y potente económicamente, de la campiña (AGUDO; HERNÁNDEZ, 2010). Con ello las imágenes opuestas de sierra/campiña que parecen prendidas en la morfología geográfica, no resultan tan incuestionables dado el olvido de las "otras sierras".

Su permanencia nos muestra cómo las apropiaciones simbólicas y percepciones sobre los espacios, que hacen territorios, no necesariamente coinciden con el conocimiento experto y objetivado defendido por la geografía.
1

A ello puede contribuir el hecho de la especial ubicación que limita con dos valles: el de la Alcudia (Castilla-La Mancha) y el de la Serena (Extremadura). 

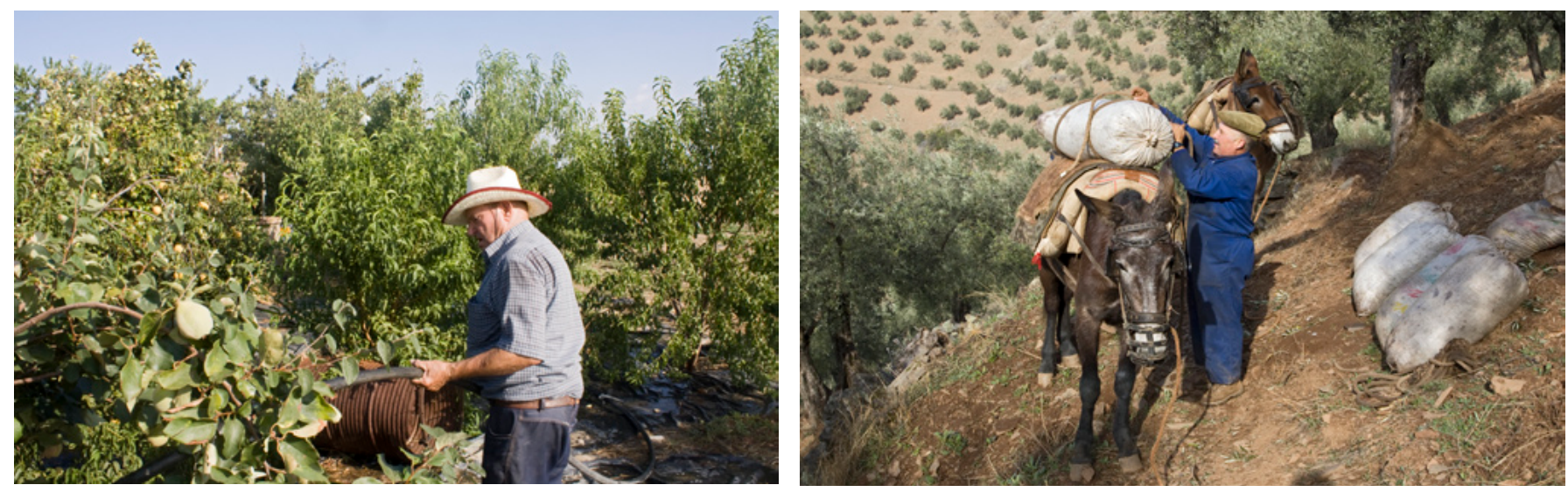

Cultivo de regadío en el Guijo

Olivarero, Pozoblanco

| fotos Fondo Gráfico IAPH

\section{UN TERRITORIO DE FRONTERAS}

Los Pedroches es tierra de fronteras y en ella podemos observar relevantes manifestaciones de la apropiación material y simbólica del espacio; es decir, interesantes procesos de construcción del territorio y de sus límites (GODELIER, 1999).

Aproximarse a su historia, a los sistemas socioeconómicos, a sus rituales y, en definitiva, a su vasto patrimonio cultural es imbuirse del concepto de frontera.

El área mantiene a lo largo de la historia una condición liminal, de muy diferentes límites, pero en definitiva una condición de frontera permanente a lo largo de las diferentes etapas históricas. Su especial ubicación en la periferia y alejada de los centros de poder, han modelado las singularidades que hoy se destacan como propias de este territorio.

Hoy la encontramos en el límite de la comunidad autónoma andaluza, en su parte más al norte, dibujando la frontera con las comunidades vecinas: Extremadura y Castilla la Mancha. Una ubicación que arranca de la provincialización de 1833, cuando las poblaciones pedrocheñas quedan definitivamente incluidas en la provincia de Córdoba y, por ende, en Andalucía. Con la implantación de nuevo orden provincial terminan una serie de ambigüedades en las pertenencias y vaivenes en los límites. Aunque se caracteriza a la frontera andaluza como de gran permanencia y estabilidad histórica (CANO GARCÍA, 1990: 48), a nivel micro, si enfocamos a las poblaciones del límite, descubrimos una articulación entre las poblaciones a un lado y a otro de las fronteras.

Así, siendo cierto que toda la zona perteneció al obispado de Córdoba, también lo es que el antiguo condado de Belálcazar, al suroeste de la comarca, perteneció a la Real Audiencia de Extremadura hasta que el proyecto de Javier de Burgos se materializa y acaba con las divisiones históricas del Antiguo Régimen. 

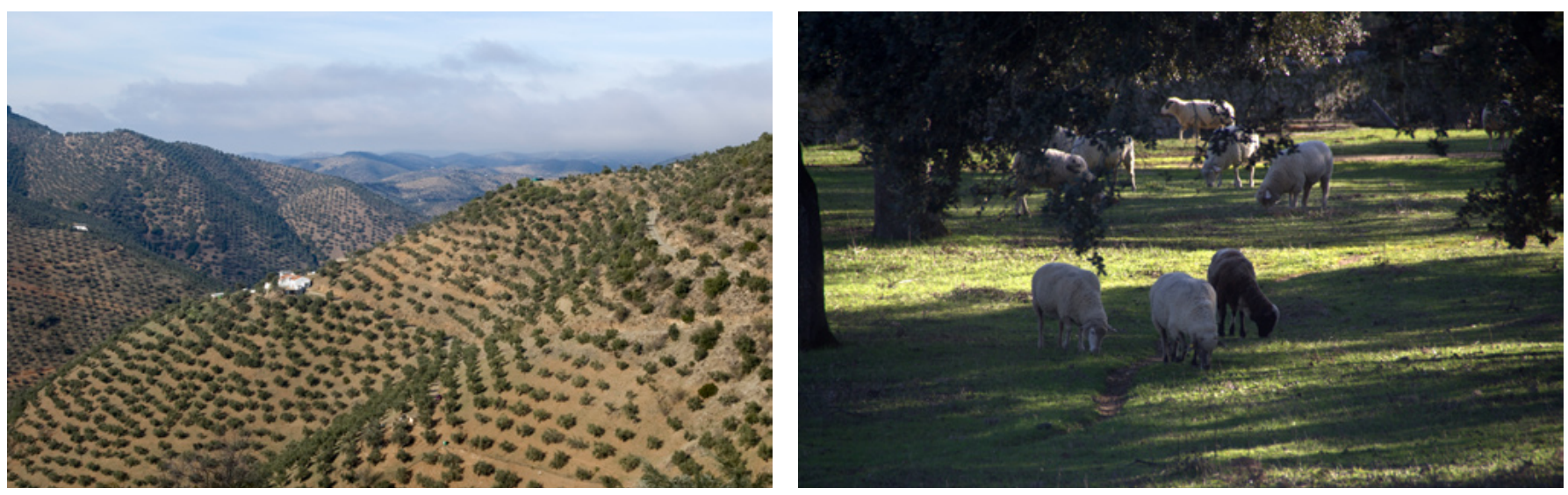

Estribaciones de la sierra, Pozoblanco | foto Fondo Gráfico IAPH

Y aún podríamos ahondar más en la búsqueda de su condición fronteriza en el pasado histórico (HERNÁNDEZ, 1999: 62). En época medieval su lejanía con respecto a Córdoba pudo estar en la base de la constitución de jurisdicciones señoriales entre las poblaciones más limítrofes; de hecho su reconquista parece que tuvo que ver con la intención de acabar con golfines y forajidos refugiados en esta zona.

Los Pedroches no han estado en el centro, ni material ni simbólicamente, de Andalucía. Si acudimos a los escritos de viajeros y literatos de los siglos XVIII y XIX rara vez encontramos referencias a estas poblaciones. De hecho, es a partir de los trabajos de corógrafos y enciclopedistas, que trabajan sistemáticamente la inclusión de las poblaciones comprendidas en las recién instauradas provincias, cuando encontramos referencias a estas poblaciones.

Y es precisamente esta condición de frontera, de encrucijada entre diferencias culturales, de aislamiento y lejanía con respecto al centro, uno de los núcleos argumentales que modelan los discursos de pertenencia de un "nosotros pedrocheños". Percepción de comunidad territorial que en absoluto es baladí puesto que es capaz de catalizar muchas de las acciones y movimientos sociales de la comarca (HERNÁNDEZ, 2005) y, por supuesto, de ser clave para entender los procesos de patrimonialización que aquí nos ocupan.

\section{UNA COMARCA DIVERSA}

Hasta aquí hemos abordado la unidad de este territorio dibujando someramente rasgos, percepciones y aspectos históricos a partir de los cuales comprender el sentido como comarca. Y en esta presentación no queremos que se identifique unidad con homogeneidad.

La unidad del territorio cultural de los Pedroches no invalida que estemos ante una comarca diversa, compuesta de núcleos de diferentes dimensiones
Ovejas pastando en la dehesa de los Pedroches | foto Aniceto Delgado Méndez 

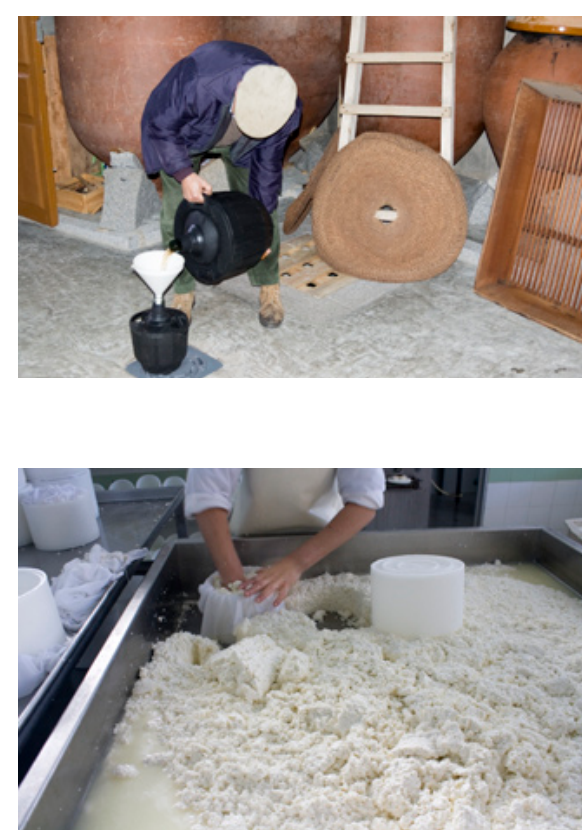

Elaboración de vino de pitarra, Belalcázar Elaboración de quesos, Villaralto | fotos Fondo Gráfico IAPH
En este proceso desempeña un papel clave la creación de una cooperativa como COVAP, que es paradigma en Andalucía. Su origen es explicado por la necesidad que tuvieron los ganaderos de unirse para poder salvar las distancias y trasportar sus productos. que conforman un sistema urbano complementario y jerarquizado hacia un polo de atracción. Actualmente Pozoblanco es la capital indiscutible del valle por su relevancia poblacional y área de influencia socioeconómica. Además de este sistema urbano, también es destacable la abundancia del hábitat disperso de cortijos y ermitas de vocaciones compartidas que nos muestran la importancia histórica de los aprovechamientos comunales en el área hasta las desamortizaciones y la reorganización y concentración de la propiedad de la tierra.

La vocación agroganadera de las dehesas de este territorio es indudable pero, la distribución espacial y especializada de las ganaderías y los cultivos tampoco resulta homogénea. Mientras que predominan al oeste el cultivo extensivo y las ganaderías ovinas, en el centro-oriente el protagonismo es para la dehesa porcina y las explotaciones de bovino de producción lechera, sin olvidar el olivar de montaña. Todo ello compone un panorama diverso a partir del cual se pueden generar imágenes territoriales cohesionadoras, en tanto que confluyen los intereses socioeconómicos de un espacio dedicado a la producción agropecuaria cuyos productos adquieren el valor añadido de la naturaleza y la cultura del territorio.

Es a partir del aprovechamiento de sus recursos endógenos (sin excluir la integración de algunos externos) como el área ha sobrevivido a las graves crisis agropecuarias y ha logrado mantener cierta dinamización socioeconómica a pesar de la regresión demográfica. $Y$ entre sus recursos estaba una memoria histórica y una especial ubicación de una amplia zona extremeñamanchega-andaluza que se organiza para dar respuesta al estancamiento y marginación de las áreas fronterizas².

La autopercepción de un hombre de los Pedroches que con su esfuerzo supera las adversidades y el olvido del centro, es otro de los argumentos centrales en la construcción de una identidad territorial, que, como hemos dicho, se construye sobre la condición de frontera. El sentimiento de unidad comarcal se reafirma a través de rasgos culturales, extremeños, andaluces y también castellanos, sin que ello suponga la negación de la pertenencia a Andalucía.

El patrimonio cultural de los Pedroches, como resultado de un proceso de selección, tomará sentido si tenemos en cuenta estas claves identitarias. 


\section{BIBLIOGRAFÍA}

- AA.VV. (2010) Paisajes y patrimonio cultural en Andalucía. Tiempo, usos e imágenes. Sevilla: Instituto Andaluz del Patrimonio Histórico, Junta de Andalucía, 2010, 2 vol. (PH Cuadernos)

- Agudo, J. (1990) Las hermandades de la Virgen de Guía en los Pedroches. Córdoba: Caja Provincial de Ahorros, 1990

- AGUDO, J.; HERNÁNDEZ, E. (2000) Serranos y Campiñeses: imágenes dicotómicas del Territorio en la provincia de Córdoba. Demófilo. Revista de Cultura Tradicional de Andalucía, vol. 36, 2000, pp. 57-74

- CANO GARCíA, G. (1987) Evolución de los límites de Andalucía y percepción del territorio. En CANO GARCíA, G. Geografía de Andalucía. Madrid: Tartesos, 1987, vol. I.

- CosgrovE, D. (2002) Observando la naturaleza: el paisaje y el sentido europeo de la vista. Boletín de la AGE, 34, 2002, pp. 63-89

- HERNÁNDEZ, E. (1999) El Valle de los Pedroches una comarca limítrofe. Anuario Etnológico de Andalucía 19951997. Sevilla: Consejería de Cultura, Junta de Andalucía, 1999

- HERNÁNDEZ, E. (2005) Fronteras culturales: la construcción de los límites culturales en el valle de los Pedroches. Tesis doctoral [en línea] <http://fondosdigitales. us.es/tesis/tesis/1742/fronteras-culturales-la-construccionde-los-limites-culturales-en-el-valle-de-los-pedroches/> [Consulta: 03/07/2014]

- GIL MUÑIZ, A. (1925) El Valle de Los Pedroches. Boletín R.A.C.L.A., n. ${ }^{\circ}$ 12. Córdoba, 1925, pp. 131-167

- GODELIER, M. (1990) Lo ideal y lo material. Madrid: Taurus Humanidades, 1990 


\section{El patrimonio arquitectónico en la comarca de los Pedroches}

M. ${ }^{\text {a }}$ Mercedes Fernández Martín | Universidad de Sevilla

URL de la contribución <www.iaph.es/revistaph/index.php/revistaph/article/view/3506>

\section{RESUMEN}

La comarca de los Pedroches, dada su trayectoria histórica, conserva interesantes muestras de arquitectura. Entre los ejemplos más significativos está la desarrollada por los Hernán Ruiz, padre e hijo, activos en la comarca durante buena parte del siglo XVI. Asimismo, conserva una interesante arquitectura popular, marcada por la utilización del granito.

\section{Palabras clave}

Arquitectura agraria | Arquitectura popular | Hernán Ruiz, el Viejo | Hernán Ruiz, el Joven | Los Pedroches | Sotomayor y Zúñiga | 


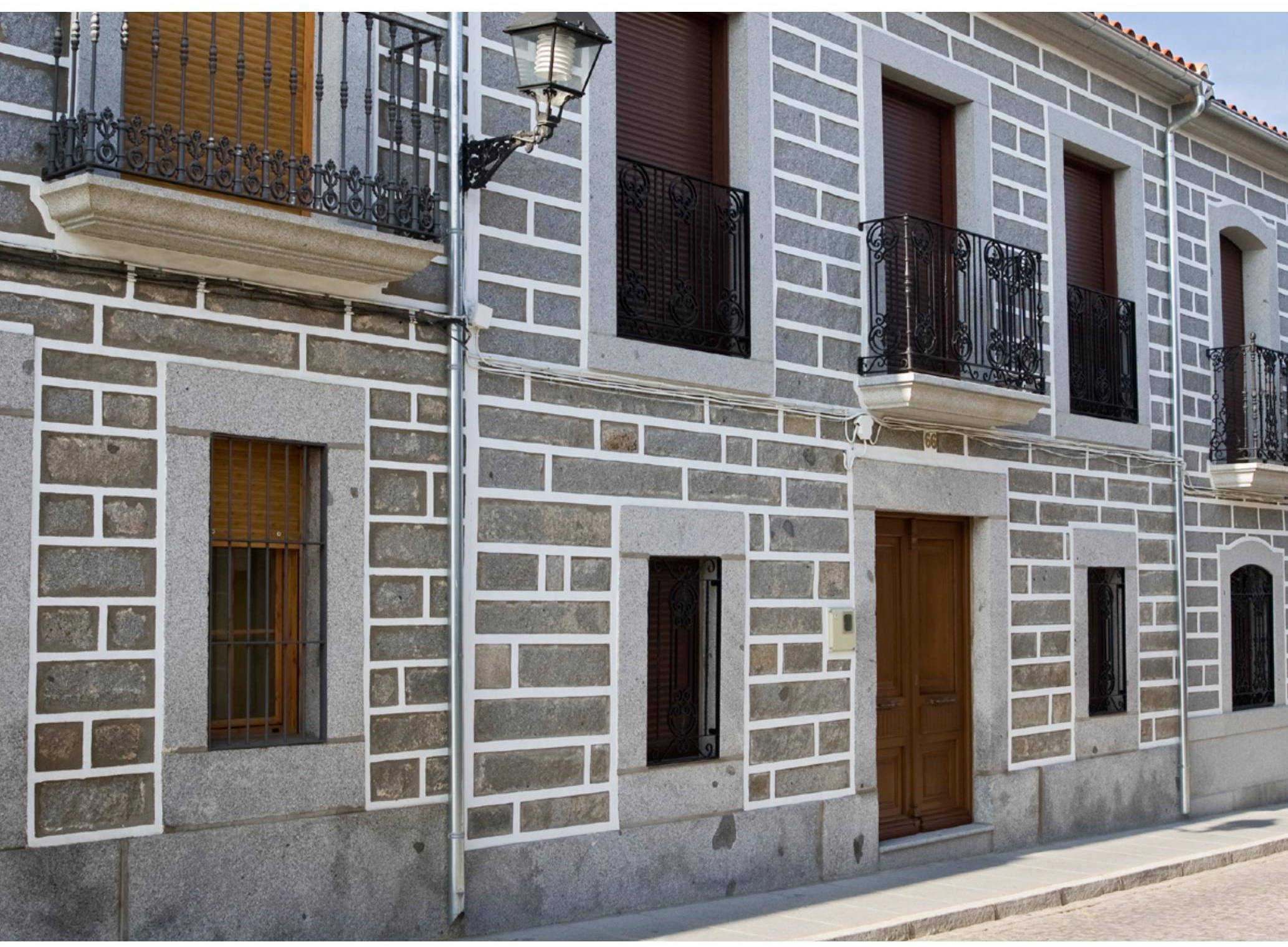

Fachada de granito en Añora | foto Fondo Gráfico IAPH 


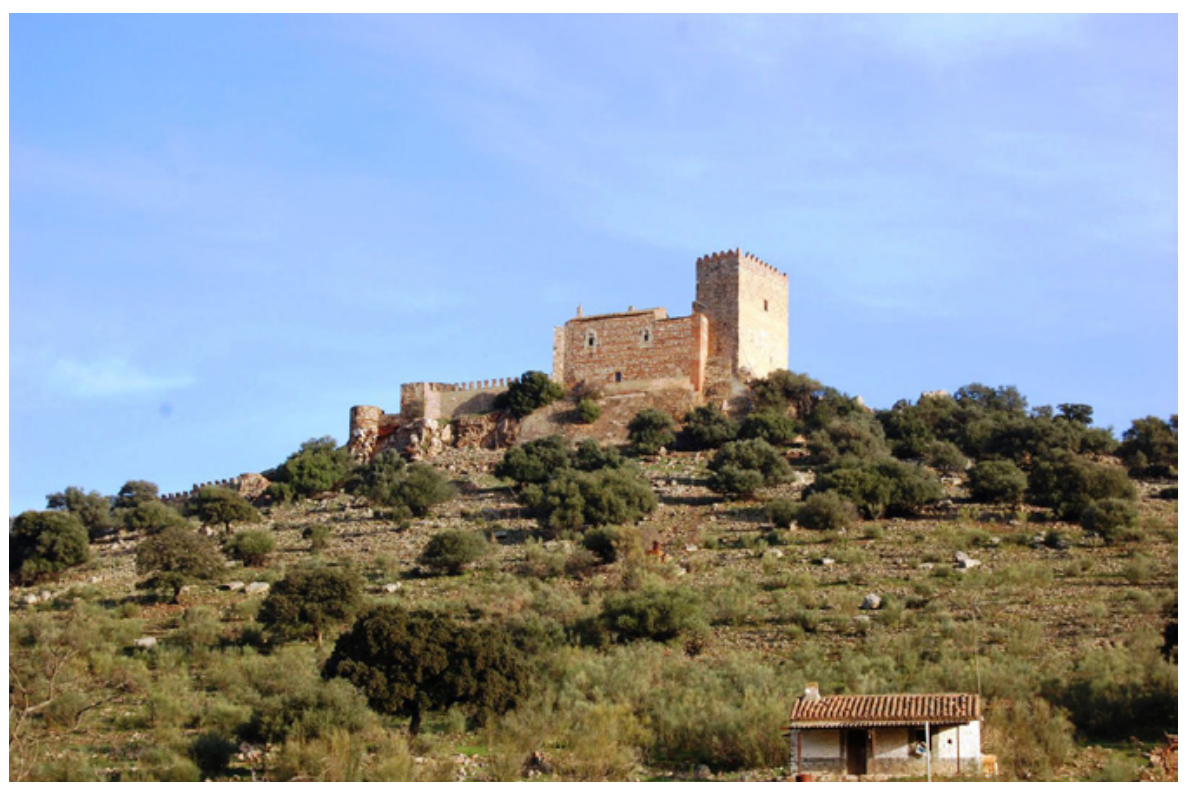

El Viso. Castillo de Madroñiz | fuente VILLAR; DABRIO; RAYA, 2006

Los Pedroches constituyen uno de los más claros ejemplos de comarca natural y una de las más extensas de la provincia de Córdoba, con unas características bien definidas, debido principalmente a su situación geográfica y a sus límites naturales. Situada al norte de la provincia de Córdoba, limita al noroeste con Extremadura, al noreste con la Comunidad Autónoma de Castilla la Mancha, sureste con la provincia de Jaén y por el sur y suroeste con Córdoba.

En la actualidad está integrada por 17 municipios: Alcaracejos, Añora, Belalcázar, Cardeña, Conquista, Dos Torres, El Guijo, Fuente la Lancha, Hinojosa del Duque, Pedroches, Pozoblanco, Santa Eufemia, Torrecampo, Villanueva de Córdoba, Villanueva del Duque, Villaralto y El Viso. Su acusada personalidad está propiciada por la existencia de un zócalo granítico sobre la que se asienta, material que va a marcar significativamente su arquitectura. Tan amplio territorio se puede dividir en dos subcomarcas, que van a propiciar asimismo su evolución histórica. En la subcomarca occidental se establecieron los señoríos de Santa Eufemia y de Belalcázar, mientras que sobre la oriental se constituyó la comunidad de las Siete Villas de los Pedroches, que salvo un período de tiempo, fueron siempre tierras de realengo. Tan dispares características históricas van a influir también en su arquitectura.

Los restos arqueológicos de diversas épocas prehistóricas aparecidos en muchos puntos de su geografía atestiguan el poblamiento de esta comarca desde antiguo, pero fue durante la dominación romana cuando gozó de una gran importancia, debido a su riqueza ganadera y a los minerales de su sub- 
suelo. La conquista árabe fortaleció aún más su tradición ganadera, teniendo sus dos núcleos más importantes en Belalcázar y Pedroche. Tras la reconquista pasó a la autoridad de la Corona, iniciándose el proceso repoblador de la zona y con ello las principales manifestaciones arquitectónicas.

Las construcciones más antiguas que se conservan se deben precisamente al proceso repoblador y están representadas por los castillos de Madroñiz y Belalcázar. El primero, situado sobre un cerro en el término municipal de EI Viso, fue construido por los árabes en los siglos XI o XII. Durante mucho tiempo la importancia de este castillo radicaba en ser la defensa del único camino que llevaba a Toledo, y pertenecer a una red de comunicación y vigilancia junto con otras fortificaciones del norte de la provincia de Córdoba y de las comunidades limítrofes. En el siglo XV pasó a formar parte del señorío de Santa Eufemia, al que ha estado históricamente vinculado. A ese período se debe su reconstrucción, siendo totalmente reformado en los siglos XIX y XX. Por su parte, el castillo de Belalcázar es uno de los monumentos más relevantes de la comarca de Los Pedroches y por tanto merecedor de un estudio individualizado ${ }^{1}$.

Al ser tierra de Reconquista la mayoría de sus pueblos se consolidaron a partir del siglo $\mathrm{XV}$, muchos de los cuales fueron en origen ventas concedidas a Córdoba por Enrique III en el camino real de la Plata, que unía Córdoba con Toledo. A esas fechas se debe la construcción de un considerable número de iglesias y ermitas donde la presencia mudéjar ha dejado su huella. Con frecuencia son construcciones que han sufrido profundas alteraciones, aunque mantienen sus sencillas estructuras y las características propias de la arquitectura vernácula, patrimonio etnográfico, que cada vez cobra más valor.

El período más importante para la arquitectura de la comarca es sin lugar a dudas el de los años finales del siglos XV y el siglo XVI, fecha en que adquiere una gran importancia el señorío de Belalcázar. Durante este período ejerció su patronazgo arquitectónico y artístico don Francisco de Zúñiga Guzmán y Sotomayor, IV conde de Belalcázar, marqués de Ayamonte y III duque de Béjar, con la realización de importantes empresas. En 1466 Alfonso de Sotomayor había levantado el castillo, la principal edificación de la población. No obstante, fue don Francisco de Zúñiga el que le dio un nuevo uso en el primer tercio del siglo XVI, uniendo a su condición de fortaleza la adecuación del edificio a palacio renacentista. Se trata de una obra singular, claramente individualizada del castillo medieval (MOLINERO MERCHÁN, 2011: 315 y ss.).

La nueva construcción se adosó en uno de los costados de la fortaleza medieval proyectada hacia la población. Las fachadas están organizadas en tres cuerpos, mereciendo mayor atención decorativa la parte superior, con una progresiva apertura de vanos. El programa ornamental se circunscribe
El estudio de las fortalezas de Belalcázar ha sido realizado en esta misma publicación por Alberto León Muñoz, al que remito. Al respecto véase también León Muñoz (2003).

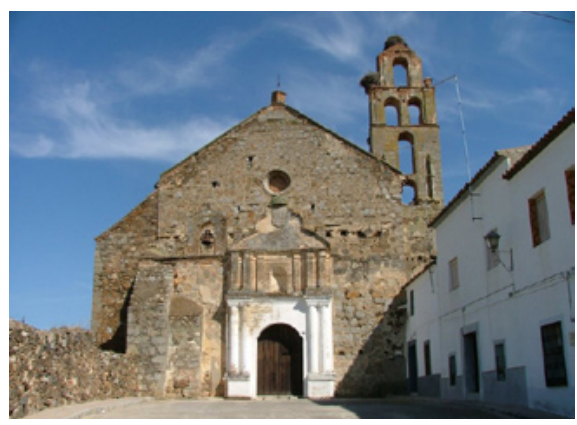

Belalcázar. Convento de los Mártires de Marruecos | fuente VILLAR; DABRIO; RAYA, 2006

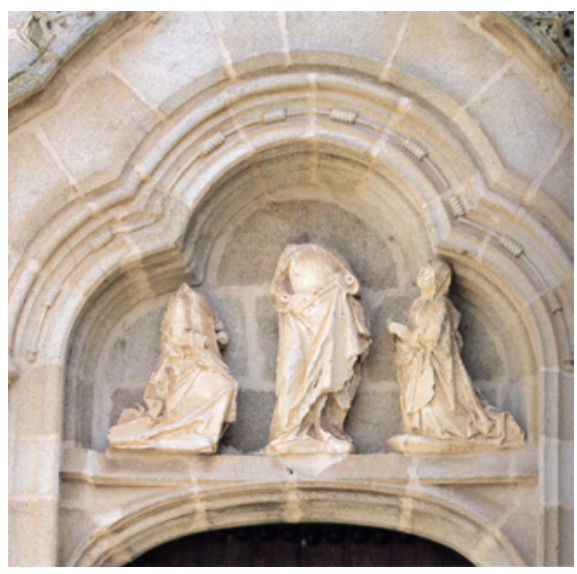

Belalcázar. Convento de Santa Clara de la Columna Siglo XVI | fuente VILLAR; DABRIO; RAYA, 2006 


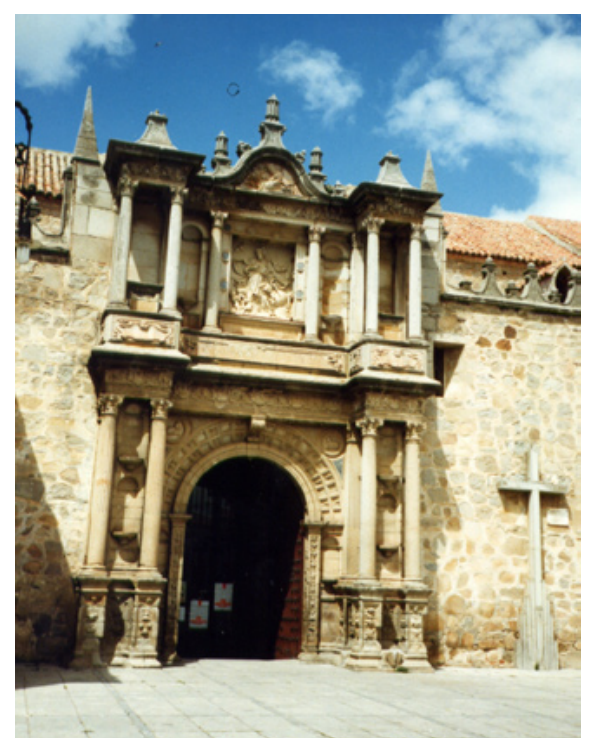

Hinojosa del Duque. Portada de la iglesia de San Juan Bautista | foto Mercedes Fernández Martín

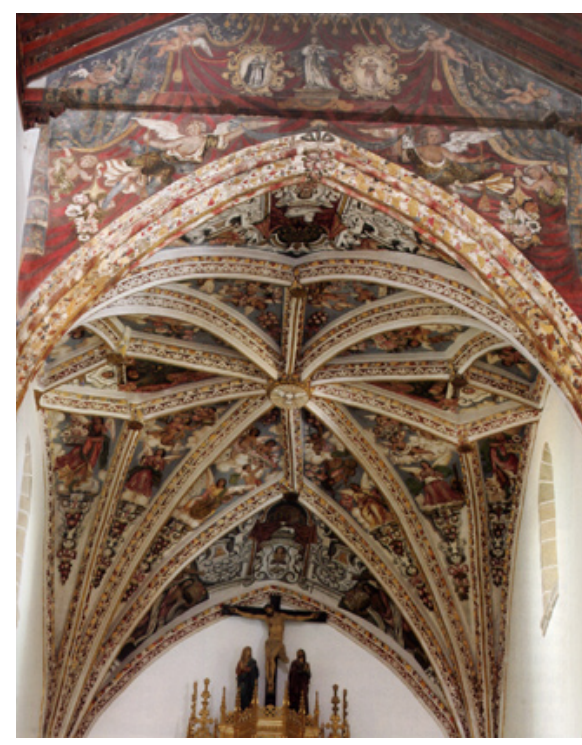

Iglesia parroquial de San Juan Bautista. Hinojosa del Duque | foto Mercedes Fernández Martín al enmarque de las ventanas y del balcón principal, con motivos del repertorio renacentista como tondos, cuernos de la abundancia, flameros, unidos entre sí por motivos en forma de $\mathrm{S}$, delfines vegetalizados enlazados por la cola y escudos heráldicos, modelos similares, aunque de menor calidad a los que decoran las ventanas de la sacristía de la iglesia parroquial de san Juan Bautista de Hinojosa del Duque. Estas similitudes avalan la atribución de la autoría de la obra a Hernán Ruiz el Viejo, aunque probablemente la ejecución material fuera de la mano de otros entalladores.

Los Sotomayor de Belalcázar ejercieron el mismo patronazgo con la fundación de nuevos conventos en la ciudad, como los de santa Clara de la Columna y el de los Cinco Mártires de Marruecos. La iglesia del convento de santa Clara de la Columna se fundó en el último cuarto del siglo XV por iniciativa de doña Elvira de Zúñiga para mausoleo familiar. El proyecto de panteón recayó en los maestros cordobeses Hernán Ruiz I y Sebastián Peñaredonda, si bien quedó sin realizar. Únicamente se labró la portada (MOLINERO MERCHÁN, 2011: 423 y ss.). Aunque ha sufrido una profunda restauración en los últimos años, la iglesia conserva su fisonomía primitiva, con una única nave cubierta con bóvedas estrelladas realzadas con pinturas murales de motivos vegetales, medallones con ángeles y símbolos pasionarios, que se fechan en el siglo XVIII. La fachada de la iglesia presenta una portada de arco carpanel presidido por un grupo escultórico en piedra con la figura de Cristo bendiciendo, flanqueado por la Magdalena y santa Clara. A las tres figuras les falta la cabeza y se pueden fechar en los primeros años del siglo XVI.

También fundación de los duques en la primera mitad del siglo XV es el convento de franciscanos de los santos Mártires de Marruecos, muy alterado en la actualidad. En 1486 se proyectó como panteón funerario para la casa de Sotomayor y en el intervino Hernán Ruiz el Joven, encargado de la construcción de la capilla funeraria de los Vargas (MOLINERO MERCHÁN, 2011: 304; 431 y ss.). Desgraciadamente, el fallecimiento del promotor hizo que no se realizara el programa escultórico. De la riqueza artística que debió tener el edificio primitivo poco queda, sólo vagos vestigios de su arquitectura y decoración renacentista. La portada presenta un arco de medio punto rebajado, enmarcado por gruesas columnas pareadas sobre pedestales. Sobre éste una hornacina con arco de medio punto, flanqueada por pilastras y rematada por frontón partido que alberga el escudo original con las armas de Sotomayor y Enriquez. Por último, también a este patronazgo se debe la construcción de la fuente del Pilar, junto a la fortaleza de Belalcázar, donde se combina la funcionalidad del abrevadero y la monumentalidad arquitectónica de la fuente.

Este patronazgo también se extendió a la cercana ciudad de Hinojosa del Duque, y en concreto a la sacristía de la iglesia parroquial de san Juan Bautista, una de las obras arquitectónicas y escultóricas más importantes 
del Renacimiento de los Pedroches. La iglesia parroquial se había construido en los últimos años del siglo XV, siguiendo modelos del gótico. A partir del segundo tercio de la centuria siguiente el edificio experimentó una total renovación, imprimiéndole sus características renacentistas, encargándose de las obras el maestro Hernán Ruiz, el Viejo. El maestro cordobés se encargó de la construcción de la puerta de la epístola, la capilla bautismal y la sacristía, obras que posteriormente concluiría su hijo Hernán Ruiz, el Joven. En el exterior la sacristía está rematada por una balaustrada de piedra formada por candeleros unidos entre sí por medio de motivos ornamentales en forma de $\mathrm{S}$, disponiéndose bajo la cornisa gárgolas esculpidas también en granito. El programa iconográfico de la misma está basado en la heráldica de la casa de los Sotomayor.

En la misma población los señores de Belalcázar fundaron el convento de la Purísima Concepción, en memoria del fundador del linaje don Gutierre de Sotomayor. El edificio quedó bajo la dirección de la orden franciscana, si bien la obra del convento se prolongó a lo largo del siglo XVII, época en las que se fechan sus portadas, en las que campean los escudos de los Zúñiga y Sotomayor, concluyéndose en 1693.

Sin lugar a dudas la participación más importante de Hernán Ruiz el Joven fue en la iglesia de san Juan Bautista de Hinojosa del Duque, donde campean los escudos nobiliarios de sus fundadores. El Joven va a proseguir las obras iniciadas por su padre, datándose su actuación en 1559, trabajando en la portada meridional del templo, aunque también resulta indudable su participación en la capilla bautismal. Asimismo, se le atribuyó el diseño de la torre-fachada, dato que no se ha podido confirmar documentalmente ${ }^{2}$. La portada se ejecutó entre 1539 y 1571, correspondiendo a la intervención de Hernán Ruiz el Viejo el diseño del vano de ingreso, mientras que a su hijo se debe la decoración del enmarque y todo el cuerpo superior, resuelto con maestría y monumentalidad.

En la capilla bautismal, aunque sin documentar, se aprecia la participación del maestro, tanto en la bóveda como en la ventana. La bóveda vaída está decorada con motivos geométricos, mientras que la ventana es una magistral lección de perspectiva, relacionada con algunas ilustraciones de su Manuscrito (MORALES, 1996: 20). Asimismo, un proyecto suyo pudo servir de base a Juan de Ochoa para trazar la torre-fachada de la iglesia, concluida en 1590, apreciable en la utilización de espejos de cerámica y el uso del hueco serliano. De los tres cuerpos del campanario, rectangular, cuadrado y octogonal, es de destacar el inferior, solucionado como un arco cuadrifronte. Asimismo, se ha querido ver la intervención del maestro y de su aparejador Sebastián de Peñaredonda en la parroquia de Santiago de Belalcázar, edificio con un proceso constructivo bastante complejo (MORALES, 1996: 18).
2

La atribución corresponde a Banda y Vargas (1974: 110). 
Las Siete Villas de Los Pedroches, por su condición de tierras realengas, con el mantenimiento de la comunidad de términos, no tuvo el patronazgo de las villas de señorío. Comprenden los municipios de Pedroche, Dos Torres (Torremilano y Torrefranca), Torrecampo, Pozoblanco, Villanueva de Córdoba, Alcaracejos y Añora. Pedroche constituye el núcleo de la comarca de su nombre y entre sus edificios religiosos sobresale la parroquia del Salvador, una de las construcciones más notables de la provincia de Córdoba. De estilo gótico mudéjar, su construcción data del siglo XVI, realizada posiblemente sobre una antigua mezquita próxima al castillo. El edificio de tres naves se cubre con armaduras de madera, siendo la central de lacería, mientras que la cabecera es de cantería con bóveda de crucería. El interior estuvo decorado con pinturas murales fechables en la primera mitad del siglo XVI de las que sólo quedan unos restos. Desde el punto de vista arquitectónico tiene gran interés su torre renacentista que se eleva, en cuatro cuerpos perfectamente diferenciados, hasta los 56 metros de altura. Fue construida entre 1532 y 1588 y en su construcción participó Hernán Ruiz II, donde incorporó un cuerpo cuadrado muy sobrio, con dos vanos por fachada a otros, cuadrado y poligonal, levantados por sus antecesores al frente de la obra. Con posterioridad a su intervención, entre 1544 y 1558, Juan de Ochoa levantó el cuerpo cilíndrico, que sirve de remate al campanario y que posiblemente también derive de un diseño de Ruiz.

Igualmente, varias iglesias parroquiales y otros templos se fechan entre los últimos años del siglo XV y los primeros de la centuria siguiente. Entre ellas está la iglesia parroquial de Dos Torres, bajo la advocación de Nuestra Señora de la Asunción. Era la iglesia de la antigua Torremilano y tiene su origen en el siglo XV, pero muy reformada en los dos siglos posteriores. Presenta tres naves cubiertas por armadura mudéjar, mientras que el presbiterio lo hace por medio de una bóveda de crucería con trompas angulares. En el lado del evangelio se abre la capilla de la Inmaculada, fundada por Pedro Gómez de Contreras, tesorero de Indias, y construida entre 1585 y 1595, por un maestro local, Bartolomé Hernández, cubierta asimismo con bóveda de crucería. En la nave de la derecha se abre otra capilla, la del Sagrario, que puede fecharse en los últimos años de aquella centuria. De las mismas fechas es también la antigua iglesia, hoy desacralizada, de Torrefranca y que estuvo dedicada a Santiago. Anterior en el tiempo es la iglesia parroquial de Nuestra Señora de la Encarnación de Santa Eufemia, pues sus orígenes se remontan a los años finales del siglo XIV o principios del XV. Responde a la típica disposición de nave única con arcos diafragma, donde abren cuatro capiIlas y una cabecera poligonal cubierta por cuarto de esferas, mientras que el resto lo hace con una armadura de madera que sustituyó a otra con decoración mudéjar, de las que se conservan algunos tableros.

La iglesia parroquial de san Sebastián de Añora fue construida también en el siglo XVI pero sufrió importantes transformaciones en los dos siglos siguien- 
tes. La iglesia de tres naves cubre la central y la capilla mayor con una armadura de madera con tirantes y decoración de lazo. En uno de los tirantes se lee la fecha de 1630. Por su parte, la parroquia de El Guijo, bajo la advocación de san Sebastián fue construida en el siglo XVI pero sufrió importantes transformaciones en los dos siglos siguientes. Similares características presenta la parroquia de san Sebastián de Torrecampo, documentada al menos desde 1550. Responde a modelos mudéjares, de tres naves y triple cabecera plana cubierta con bóveda de crucería.

Otras obras arquitectónicas de gran presencia en la comarca de los Pedroches son las ermitas, tanto las dedicadas a advocaciones marianas como las consagradas a diferentes santos, donde la devoción popular encuentra un amplio eco con un gran número de construcciones de carácter popular. Entre las primeras destaca la de Nuestra Señora de Gracia de Alcantarillas en Belalcázar, que sigue un tipo muy característico, con tres naves y capilla mayor plana, cubierta con bóveda de crucería gótica que se puede fechar a fines del siglo XV o comienzos del XVI. El granito, abundante en la comarca, alternado con la cal, son los materiales empleados e imprime un sello inconfundible a esta arquitectura. Algunos materiales son de acarreo, entre ellos destacan varios capiteles y algunas inscripciones de época romana. Característico de esta ermita, y de otras muchas de este tipo, es el pórtico, que en el caso de la que nos ocupa se extiende por parte de las fachadas laterales. Belalcázar también cuenta con varias ermitas de origen medieval pero muy alteradas donde lo más destacado, en las de nave única como las de san Antón y san Sebastián, son los arcos diafragma, tan frecuentes en la comarca. También de origen mudéjar es la ermita de san Sebastián en Hinojosa del Duque. Su planta presenta la típica disposición de las ermitas serranas, caracterizadas por la simplicidad y funcionalidad de sus elementos arquitectónicos y su sobriedad decorativa. Lo que imprime carácter a esta arquitectura religiosa popular son los grandes arcos diafragma contrarrestados al exterior por contrafuertes.

Otras ermitas son compartidas por varios pueblos como de la Virgen de Luna en Pozoblanco y Villanueva de Córdoba; la Virgen del Camino y de Consolación, veneradas en Belalcázar e Hinojosa del Duque; la Virgen de las Cruces en El Guijo, Torrecampo y Santa Eufemia, cuya ermita se encuentra a pocos kilómetros de la primera que, aunque muy reformada en el siglo $\mathrm{XX}$, en origen corresponde a una construcción del Setecientos. Por último, la ermita de la Virgen de Guía cuyo patronazgo y devoción se extiende a cinco villas, Alcarecejos, Dos Torres, Fuente la Lancha, Hinojosa del Duque y Villanueva del Duque. Se levanta al norte de Villanueva del Duque, muy cerca del núcleo urbano y el edificio actual sustituye a otro anterior mas modesto que data de las primeras décadas del siglo XVI. Su exterior es severo y de gran solidez, del cual sólo son destacables los contrafuertes que rodean el edificio y la fachada principal, totalmente de granito, decorada

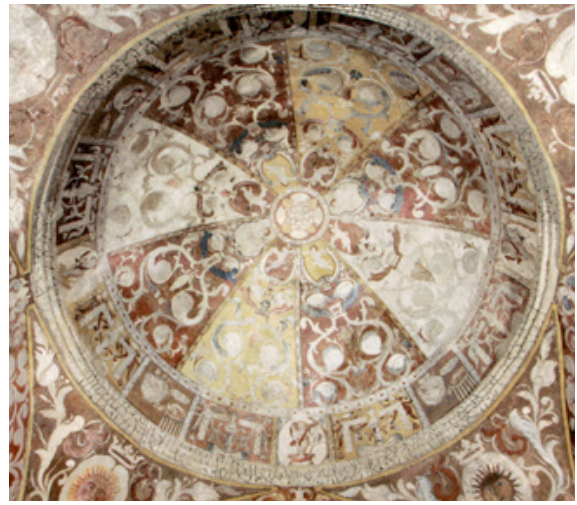

Torrecampo. Ermita de la Virgen de Gracia, s. XVI | fuente VILLAR; DABRIO; RAYA, 2006

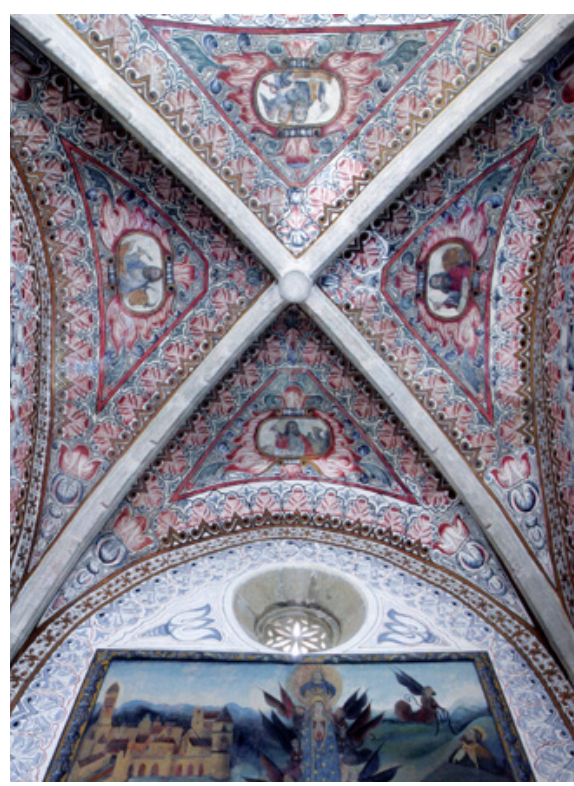

Villanueva del Duque, ermita de Ntra. Sra. de Guía | fuente VILLAR; DABRIO; RAYA, 2006 
con un arco gótico y un rosetón de época tardía. Más interesante resulta la arquitectura del interior, formada por tres naves, separadas por columnas graníticas que sustenta airosos arcos, tres a cada lado, y un púlpito en piedra de 1567. Sin duda es el presbiterio el espacio de mayor mérito artístico, protegido por una reja de 1587, presenta bóveda de crucería y sus muros se encuentran pintados al fresco, restaurados entre 1998 y 2002. Muy deteriorados, sólo la escena frontal puede considerarse original, con escenas de la Asunción y la coronación de la Virgen.

Otras muchas ermitas fueron remodeladas o construidas de nueva planta en el siglo XVII y XVIII, como las de Añora dedicadas a san Pedro, reformada en 1694 y a la patrona, la Virgen de la Peña, construida en el siglo XVIII. Dos Torres cuenta con varias como la de la patrona, Nuestra Señora del Loreto, reconstruida entre 1714 y 1766, si bien la más antigua es la de san Bartolomé, del siglo $\mathrm{XVI}$. En otras ocasiones muchas de estas ermitas fueron reconvertidas en parroquias, como las de san Bartolomé y san Sebastián, ambas en Pozoblanco.

Por otra parte, muchos edificios religiosos se han perdido, reconstruyéndose o levantándose de nueva planta en la segunda mitad del siglo XX. Entre la década de 1950 y 1960 el arquitecto diocesano Carlos Sáenz de Santamaría realizó las parroquias de Cardeña y Conquista, así como la iglesia del Dulce Nombre de Jesús en Villanueva de Córdoba, uno de los edificios más interesantes de ese siglo en la provincia. En otros se han conservado algunos vestigios del primitivo edificio como la iglesia parroquial de Alcaracejos, levantada sobre la antigua en 1965 por el arquitecto Daniel Sánchez Puch. De la antigua fábrica se conserva una portada gótica de granito, labrada en ladrillo con un arco conopial y una decoración tosca, enmarcándose el conjunto por un alfiz a base de pomas o bolas y que puede fecharse en los últimos años del siglo XV.

Frente a la arquitectura religiosa, la comarca de los Pedroches cuenta con una interesante arquitectura popular de gran originalidad, con su caserío de viviendas de una o dos plantas como máximo, con huecos muy pequeños, con muros de mampostería blanqueados, donde la piedra queda con frecuencia vista, principalmente en la segunda planta. El granito es el gran protagonista, extendiéndose en líneas por la fachada o recercando los huecos, principalmente el de portada. Las jambas y dinteles suelen ser monolíticos y en ocasiones llevan relieves o incisiones con fechas, adornos o símbolos religiosos. En Añora se conservan calles enteras con fachadas de sillares de granito remarcados de blancas tiras y el casco histórico de Dos Torres, ha conservado a través de los siglos la tipología de la vivienda tradicional, con un alto valor patrimonial, lo que le ha supuesto la declaración como bien de interés cultural, con la categoría de conjunto histórico, con casas con artísticas portadas de remarcados dinteles y escudos heráldicos que reflejan la importancia de la villa en el pasado. 

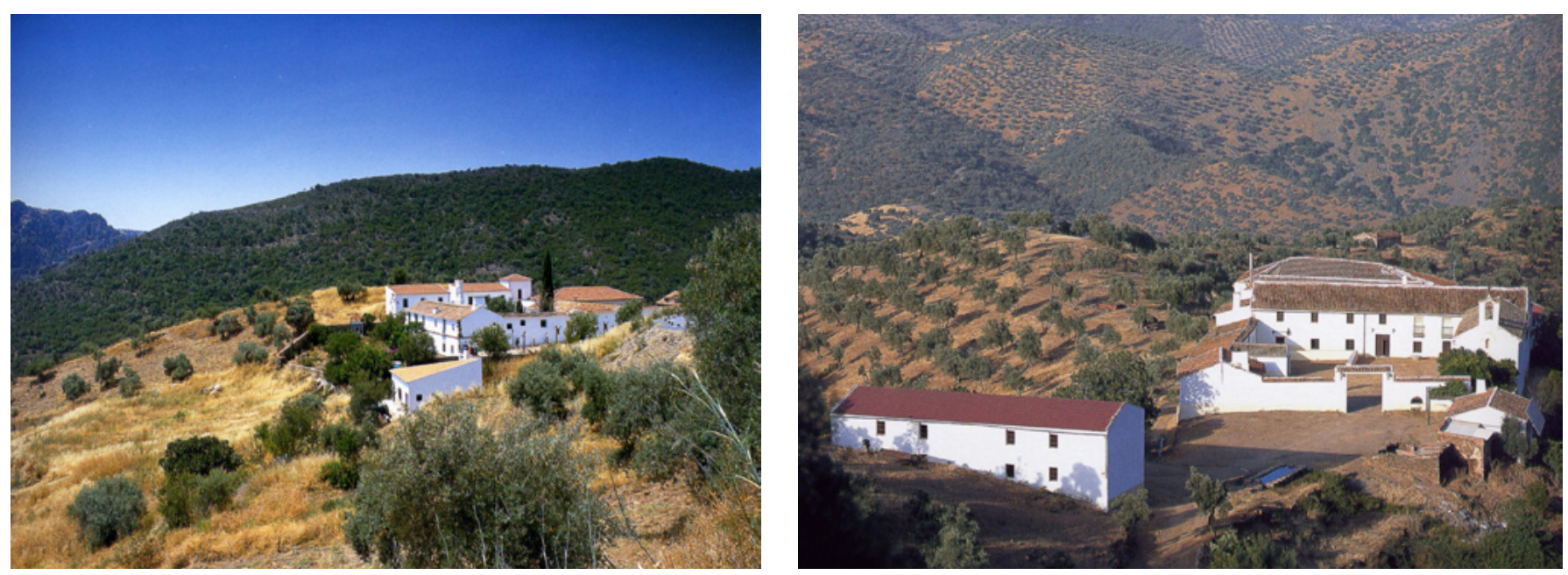

Pozoblanco. Cortijo de la Canaleja (izquierda) y cortijo de Pedrique (derecha) | fuente AA. VV., 2000

Asimismo, dada la actividad agropecuaria de la comarca, hay que hacer mención a la arquitectura agraria, que se adapta al carácter funcional y exigencias productivas de las explotaciones a las que se han vinculado los edificios. Al estar en uso muchas de estas explotaciones ha propiciado la conservación y la recuperación de un importante número de conjuntos, si bien en ocasiones se ha alterado su fisonomía primitiva. Por su carácter de penillanura aplanada por la erosión han predominado históricamente las formaciones de dehesa, con explotaciones ganaderas y de olivar. Entre los edificios más representativos cabe destacar El Pizarro en El Viso, Cantos Blancos en Belalcázar y Casa de la Barquera y Casilla Trapillos de las Monjas en Hinojosa del Duque, dedicadas principalmente a la explotación de ganado ovino (AA.VV., 2006: tomo I, p. 551).

En torno a los núcleos urbanos, y en especial en los términos de Pozoblanco, Dos Torres, Añora y Pedroche, con explotaciones intensivas de ganado vacuno, se han alterado profundamente las construcciones como se observa en El Escribano de Dos Torres o el Cortijo Barranco Serrano en Añora. Tras la ganadería tienen un papel muy importante los cultivos del olivar, localizándose sobre todo en los términos de Pozoblanco, Alcaraceños y Villanueva de Córdoba, entre los que destacan los cortijos de La Canaleja, La Aliseda o de Pedrique. Este último perteneció a una congregación de ermitaños del Yermo de Córdoba, de ahí que tenga mayor entidad y dimensiones que otros edificios vinculados a la explotación del olivar. Actualmente responde a una estructura cerrada formada por tres volúmenes edificados, dispuestos perpendicularmente a la fachada de acceso y articulados en torno a dos patios $y$ un jardín (AA.VV., 2006: tomo I, pp. 599 y ss.). El edificio está muy alterado al haberse habilitado como residencia sede de la Fundación Aurelio Teno, con un museo dedicado al artista cordobés. 


\section{BIBLIOGRAFÍA}

- AA.VV. (2006) Cortijos, haciendas y lagares: arquitectura de las grandes explotaciones agrarias de Andalucía: Provincia de Córdoba. Sevilla: Junta de Andalucía. Consejería de Obras Públicas y Transportes, 2006

- BANDA Y VARGAS, A. (1974) El arquitecto andaluz Hernán Ruiz II. Sevilla: Universidad de Sevilla, 1974

- BorRÁs GUALIS, G. M. (1990) El Islam. De Córdoba al mudéjar. Madrid: Silex, 1990

- CAMACHO mARTínez, R. (1986) Aportaciones al estudio de Hernán Ruiz III. Aptheca, n. ${ }^{\circ}$ 6, Córdoba, 1986

- FERNÁNDEZ GONZÁLEZ, R. (1969) El castillo de Belalcázar. B.R.A.C., n. ${ }^{\circ}$ 89, Córdoba, 1969

- JoRdANO BARBUdo, M. ${ }^{a}$ Á. (2013) Córdoba en el Camino Mozárabe de Santiago. El arte mudéjar, encuentro de culturas. En Actas II Congreso Internacional Camino Mozárabe de Santiago, Badajoz: CEDER "La Serena", 2013

- LEÓN MUÑOz, A. (2003) Las fortalezas de Belalcázar (Córdoba). Análisis arqueológico de su arquitectura (ss. IX-XIX). Córdoba: Publicaciones Universidad de Córdoba, 2003

- MÁRQUEZ TRIGUEROS, E. (1995) Iglesias medievales del Valle de los Pedroches. Córdoba: Grupo PRASA, 1995

- MOLINERO MERCHÁN, J. A. (2006) Iglesia parroquial de Nuestra Señora de la Asunción de Dos Torres. Córdoba: Ayto. Dos Torres, Diputación Provincial de Córdoba, 2006

- MOLINERO MERCHÁN, J. A. (2007) El convento de Santa Clara de la Columna de Belalcázar. Estudio HistóricoArtístico. Córdoba: Diputación Provincial de Córdoba, Delegación de Cultura 2007

- MOLINERO MERCHÁN, J. A. (2008) Villanueva del Duque. Patrimonio monumental y artístico. Córdoba: Ayto. Villanueva del Duque, 2008

- MOlinero MERChÁN, J. A. (2011) Palacio renacentista de Belalcázar. Humanismo del tercer Duque de Béjar. Córdoba: Servicio de publicaciones Universidad de Córdoba, 2011

- MORALES, A. J. (1996) Hernán Ruiz el Joven. Madrid: Akal, 1996

- MORENO VALERO, M. (2001) La vida tradicional en los Pedroches. Córdoba: M. Moreno, 2001

- NIETO CUMPLLIDO, M. (1982) Informe históricoartístico sobre la iglesia parroquial de San Juan Bautista de Hinojosa del Duque (Córdoba). Córdoba: Parroquia de San juan Bautista (Hinojosa del Duque), 1982
- OCAÑA TORREJÓN, J. (1973) El castillo de Santa Eufemia. B.R.A.C., n. ${ }^{\circ}$ 93, Córdoba, 1973

- VILLAR MOVELLÁN, A. (dir.) (1995) Guía artística de la provincia de Córdoba. Córdoba: Servicio de Publicaciones de la Universidad de Córdoba, 1995

- VILLAR MOVELLÁN, A.; DABRIO GONZÁLEZ, M. ${ }^{a}$ T.; RAYA RAYA, M. ${ }^{a}$ Á. (2006) Guía artística de Córdoba y su provincia. Córdoba: Ayuntamiento de Córdoba; Sevilla: Fundación José Manuel Lara, 2006 


\section{La música tradicional en el valle de los Pedroches}

José M. a Sánchez Fernández | Grupo ALIARA

URL de la contribución <www.iaph.es/revistaph/index.php/revistaph/article/view/3501>

\section{RESUMEN}

El valle de los Pedroches, por su condición de zona fronteriza, ruta de trashumancia de los pastores extremeños y norteños, tierra de paso de viajeros, peregrinos, trovadores y juglares, ha acumulado una influencia extraordinaria y definitiva en su acervo cultural y social y, cómo no, en la tradición oral de la música que atesora, que se ha conservado en el tiempo casi intacta gracias al hecho natural del aislamiento y hermetismo que produjo el abandono de esta comarca como vía al norte.

Palabras clave

Andalucía | Córdoba (Provincia) | Música tradicional | Valle de los Pedroches (Córdoba) | 


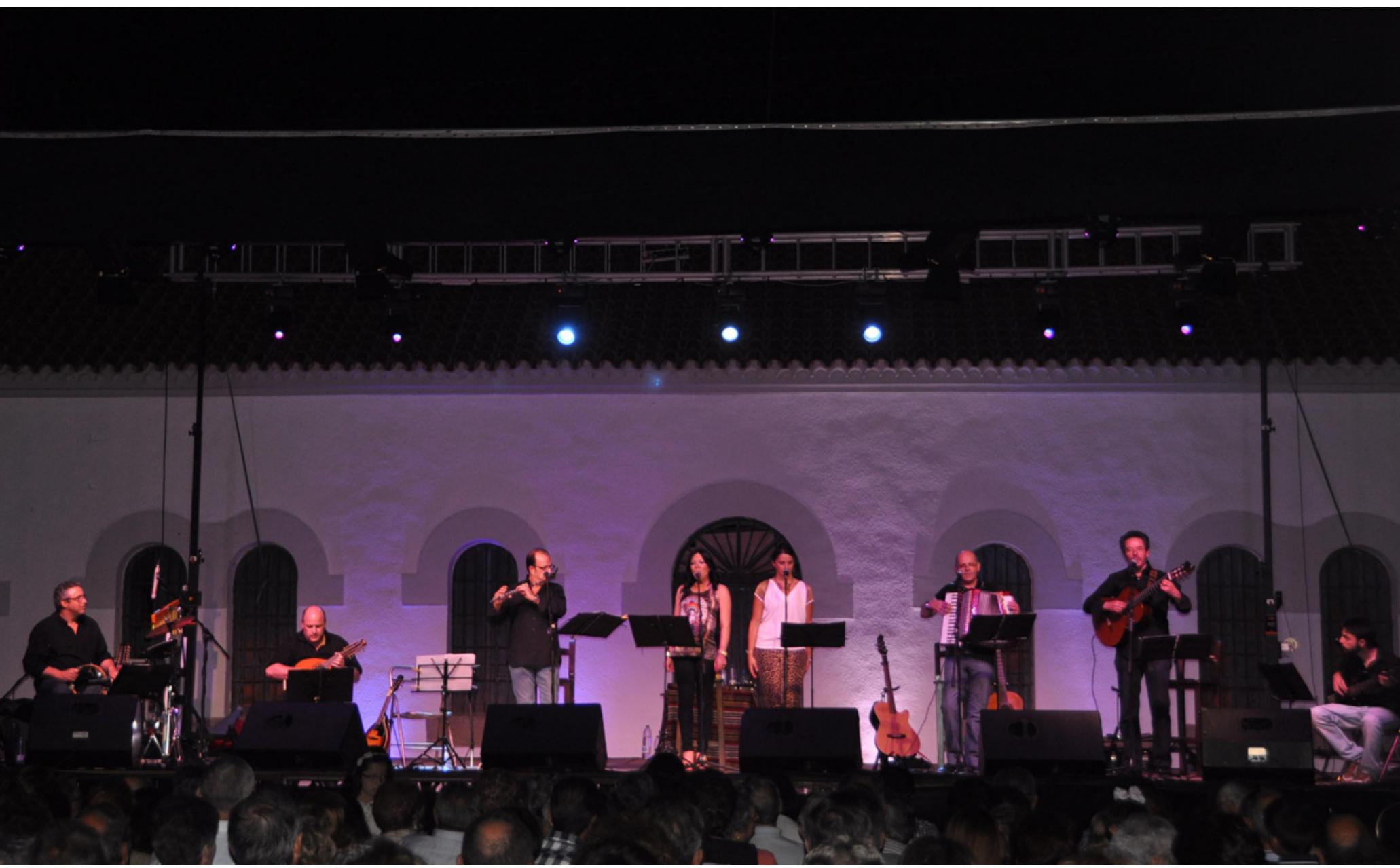

Grupo de música tradicional ALIARA. Pozoblanco (Córdoba) | foto www.pozoblanco.es 


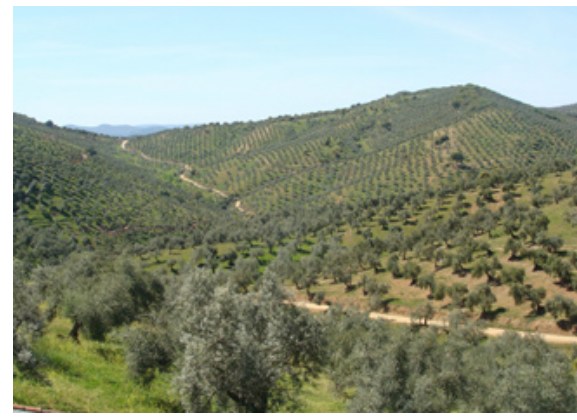

Olivar de los Pedroches

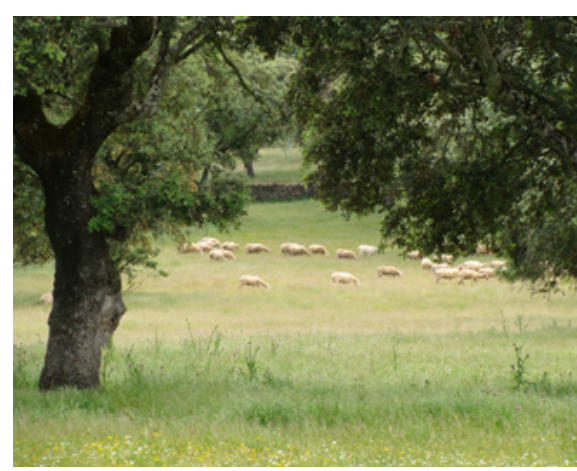

Dehesa de los Pedrohes

| fotos Eva Gaitán Romero
Al norte de Córdoba se sitúa el valle de los Pedroches o los Pedroches o la comarca de los Pedroches; prefiero la primera, si me permiten. Tierra de las bellotas por su inmensa dehesa de encinar; de oro verde ecológico y serreño por su escondido, sobrio, humilde y duro olivar; de gentes antaño sencillas, castigadas, olvidadas y justas, de carácter poco andaluz mirando más a La Mancha y Extremadura, con las que nos asemejamos por claras señas de identidad confluyentes. Fue calzada esencial con los romanos, zona fronteriza de Al-Ándalus y paso territorial en el camino de Córdoba a Toledo, obligado hasta que cayó en desuso al desviarse la salida de Andalucía hacia el centro de la Península por Despeñaperros. Y fue, afortunadamente, ruta de trashumancia de los pastores extremeños y norteños, así como viajeros, peregrinos, trovadores y juglares que influyeron extraordinaria y definitivamente en el acervo cultural y social y, cómo no, en la tradición oral de la música. Sin olvidar, claro está, la semilla musical plantada por monjes predicadores en sus misiones evangelizadoras. Si a esto le añadimos la migración que se dio después de la Reconquista y que trajo a los Pedroches personas del norte e incluso de Portugal, nos explicamos las numerosas tonadas y variaciones musicales casi idénticas a las que se dan en Cantabria, Galicia o Castilla.

De esta forma, nuestra música tradicional se ha conservado en el tiempo casi intacta no por la diligencia y fervor de sus habitantes, ni menos aún por el buen hacer de una política de cultura tradicional ni siquiera existente, sino por el hecho natural del aislamiento y hermetismo que produjo el abandono de esta comarca como vía al norte que, en mi opinión se convirtió junto con la Alpujarra granadina y la sierra onubense, en la más rica reserva de música de tradición oral de Andalucía. Lo cual no indica, en absoluto, que sean precisamente las zonas más investigadas y estudiadas a esta sazón.

Para terminar de centrarnos, concluiremos en que el hecho decisivo y trascendental de la falta de una rigurosa investigación antropológica en los Pedroches, nos sitúa ante una grave carencia de bases y argumentos que nos ayuden a analizar cualquier trabajo de recopilación y estudio de la música tradicional. No obstante, y hasta la fecha, sólo existe una obra dedicada a este fin firmada por el musicólogo Luis Lepe Crespo, La Música de Los Pedroches (Publicaciones obra social y cultural Cajasur, 2008), que realiza un estudio musical y literario basado en recopilaciones efectuadas por el mismo autor y por las aportaciones recogidas o realizadas por otras firmas, entre ellas, el archivo del grupo de música tradicional ALIARA y del que firma.

En el año 1978, ALIARA, al igual que otras formaciones existentes en este país, denostadas por los llamados estudiosos del folclore, pero que sin sus discos, conciertos y labor de divulgación no se hubiera mantenido el interés por estas músicas y los trabajos de aquellos dormirían el sueño de los justos en las estanterías de las bibliotecas, sacó del abandono la música tradicional de los Pedroches, descubriendo un yacimiento que fue explotado poste- 
riormente por otras personas, grupos y estudiosos de la comarca, existiendo otros trabajos y monografías privados, tan importantes como desconocidos, que esperan su publicación o dación, y que pueden significar una extraordinaria aportación de incalculable valor a la memoria musical y cultural de esta tierra. Eterna disyuntiva para las administraciones públicas: ¿producción propia o colaborar con lo privado?; y siempre se interpone el ego de ambas.

Para caracterizar nuestra música diría que nos movemos entre una extensa y riquísima tradición de simbología religiosa, devenida de la transformación de cultos profanos inmemoriales, y otros modos heredados o propios de dos culturas bien diferenciadas, la del olivar y la de la dehesa. Veamos:

$>$ En la gran dehesa: los Pedroches tiene la mayor dehesa de encinar de Andalucía, unas 60.000 ha de medianos y grandes propietarios, por lo que nos hemos podido encontrar con familias de buena posición, de nivel educativo aceptable y dedicadas al trigo, al picón, a la cría del cerdo y a la vaca roja. Hemos podido recoger, pues, canciones de carboneros, piconeros, de siembra, de siega, de trilla, de pastoreo y algunos romances que hemos visto

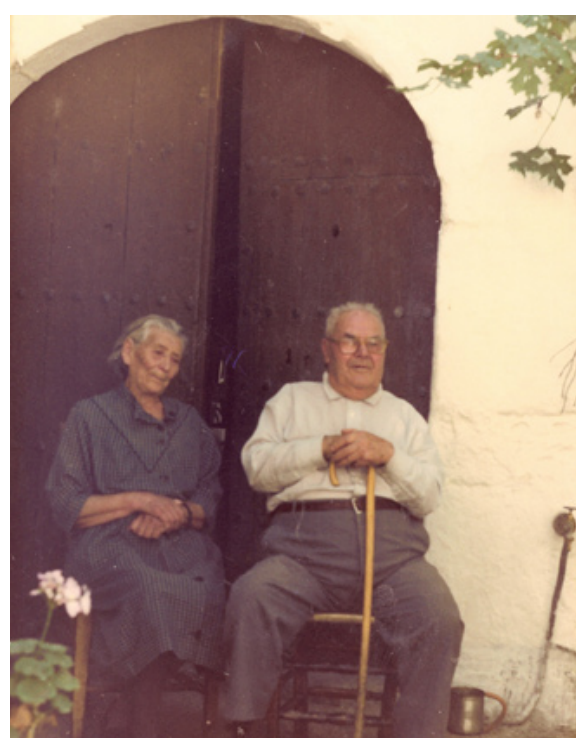

Juan Herruzo Peralbo. Informante, 1981 | fuente Archivo Aliara en otros terrenos.

$>$ En la gran sierra de olivar: este ámbito geográfico merecería un estudio aparte porque en él se ha desarrollado a través de los años una forma de vida tal que por sí misma generó una cultura y unas pautas de conducta singulares, lo que nosotros llamamos la "cultura del olivar". Explotado desde el siglo XIX, con una extensión de 25.000 hectáreas y 3.000.000 de olivos de sierra escabrosa, llegó a conformar una sociedad poco controlada y libre que derivó en un folclore basado en las faneguerías o grupos de trabajo que mantenían su propia autoría de coplillas, canciones y romances. La cultura del olivar pues, nos ha proporcionado la fuente principal de la jota serrana, de influencia principalmente manchega, con una ingente variedad en las melodías, parecidas unas, y otras no, a las de otros lugares, y a cientos de letras en su mayoría compuestas. También hemos escuchado cantar historias de hechos acaecidos en el pueblo o durante la recolección, a modo de romances, canciones dedicadas al manijero, canciones de corro, bromas recibidas por los rondadores de otros cortijos; siniestros y pesados juegos impensables en estos días pero que entonces hacían la delicia de todos.

$>$ En los núcleos de población y la simbología religiosa: la tradición musical en el ámbito urbano está relacionada con las festividades de los patronos y patronas y con los ciclos litúrgicos, así como por una relación desordenada y aleatoria de romances tradicionales, principalmente fronterizos y castellanos, numerosas canciones infantiles, auroras, cantos de pasión, rogativas y un enorme y bello repertorio de villancicos, romances de navidad y aguinaldos.

Y todo esto lo puede escuchar el lector en la discografía del mencionado grupo ALIARA. Que lo disfruten. 


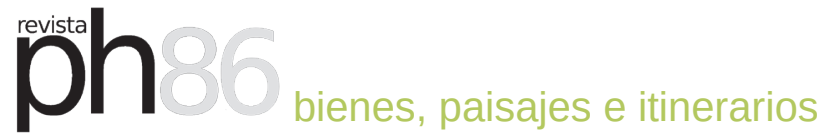

\section{Las rutas culturales de los Pedroches}

Asociación ADROCHES para el Desarrollo Rural de Los Pedroches

URL de la contribución <www.iaph.es/revistaph/index.php/revistaph/article/view/3502>

\section{RESUMEN}

La comarca de los Pedroches se encuentra situada en el norte de la provincia de Córdoba, tierra fronteriza entre Andalucía, Castilla la Mancha y Extremadura; situación privilegiada que dota este territorio de una amplia variedad de matices su paisaje, cultura, gastronomía y patrimonio. Integrada por 17 municipios, es la comarca más extensa de Andalucía. Todos ellos conforman una unidad, tanto ecológica como cultural, que le da consideración de comarca natural.

Su ubicación geográfica -frontera con las provincias de Badajoz y Ciudad Real-, unida a sus características físicas -el batolito que cruza la comarca, materia prima para las construcciones de granito de la zona-, la semejanza paisajística -tierras de dehesa-, y la explotación de los recursos, contribuyen a establecer vínculos entre los Pedroches, la comarca extremeña de la Serena y la castellano manchega de Alcudia.

\section{Palabras clave}

Andalucía | Córdoba (Provincia) | Dehesas | Gastronomía | Patrimonio cultural | Patrimonio natural | Rutas culturales | Valle de los Pedroches (Córdoba) | 


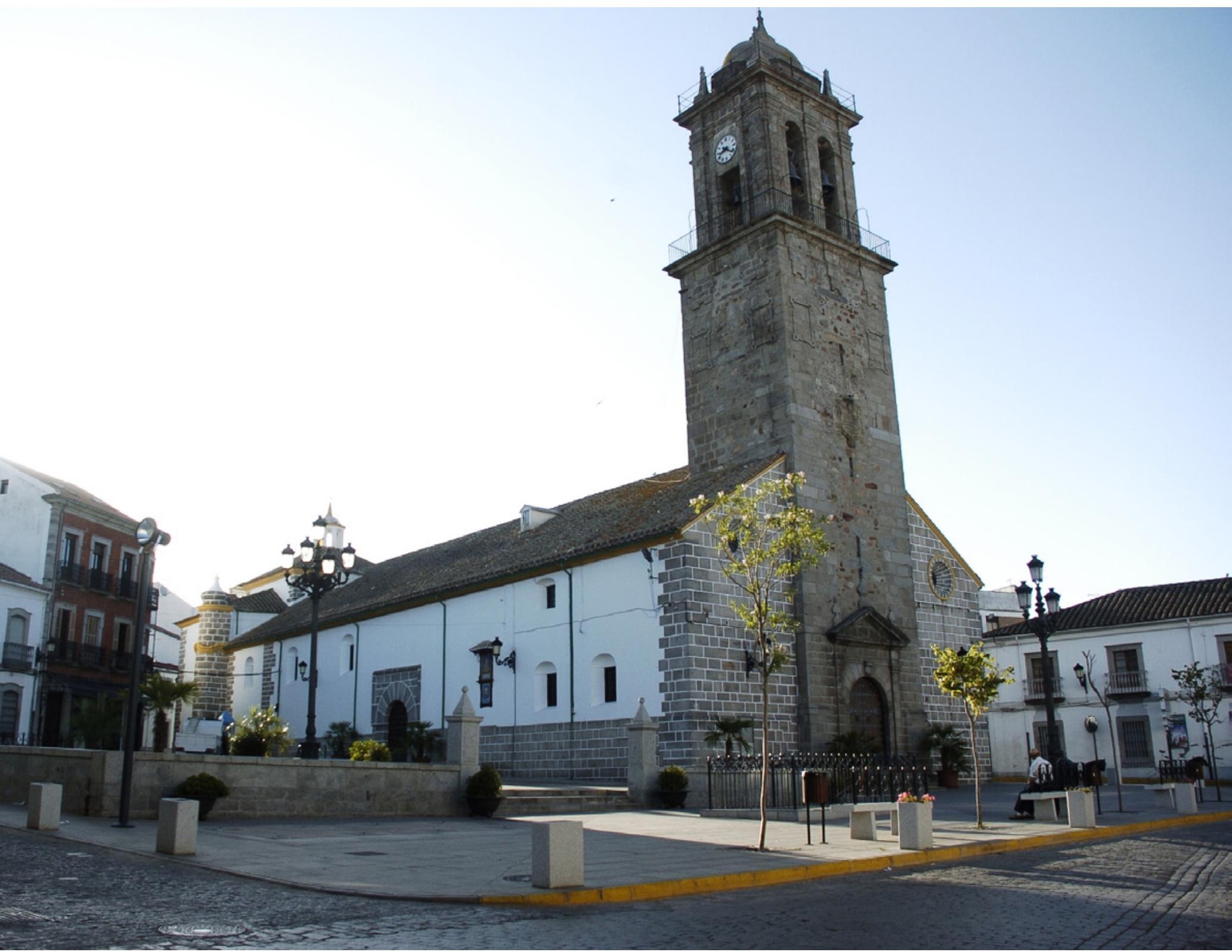

Parroquia de San Miguel. Villanueva de Córdoba | fuente Fondo fotográfico de la Asociación ADROCHES (para todas las imágenes del artículo) 


\section{VÍAS PECUARIAS, CAÑADAS REALES Y LOS CORDELES}

Su situación geográfica, como zona intermedia entre Andalucía, Castilla la Mancha y Extremadura, acentúa su carácter de territorio de frontera histórico-cultural, a la que ha contribuido de forma predominante su condición de paso obligado en las antiguas comunicaciones entre la meseta y Andalucía. Según los estudios realizados, esta circunstancia se daría desde las primeras edades del hombre, aunque fue durante el periodo califal cuando esta condición de lugar de tránsito adquiere mayor relevancia, puesto que el camino que unía Córdoba y Toledo atravesaba los Pedroches.

Este camino aprovechaba en parte una antigua calzada romana, y era imprescindible en el desplazamiento de las zonas atlánticas y levantinas con el eje central de la Península. Como prueba de ello, podemos encontrar todavía hoy restos de antiguos caminos, como la cañada real soriana o la cañada real de la Mesta, testigos de la trashumancia y el transporte de mercancías, así como las antiguas posadas y fondas que daban cobijo a los viajeros, como la antigua posada del Moro en Torrecampo.

Sirvieron para la comunicación de hombres y culturas. Gracias a los movimientos pecuarios, comarcas aisladas como los Pedroches o el valle de Alcudia, recogieron aspectos etnográficos que hicieron propios y que aun perviven en las tradiciones locales, demostrándonos que la identidad actual es heredera de una relación entre pueblos.

La gastronomía y el folclore son para el visitante testimonio de la riqueza de matices de una tierra fronteriza, demostrando en sus platos -dónde predominan los derivados del cerdo ibérico- $y$ en sus tradiciones, claramente influenciados por el paisaje, sus usos y aprovechamientos, la personalidad que hace única esta comarca cordobesa.

Paisaje de dehesa

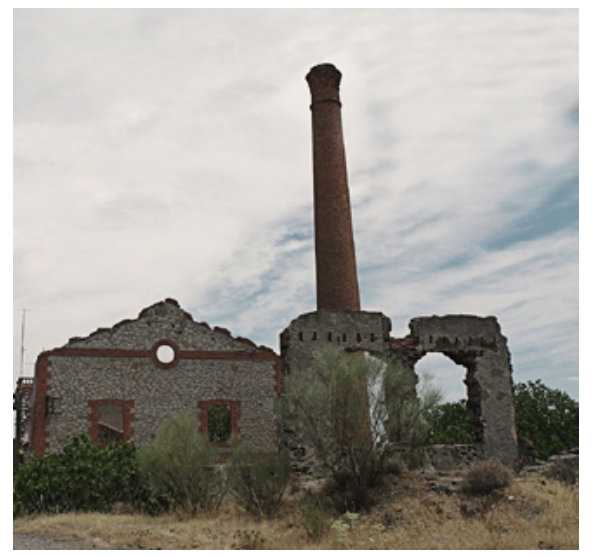

Minas del Soldado. Villanueva del Duque

Los restos arqueológicos que se distribuyen a lo largo y ancho de su territorio, nos hablan de la importancia de los antiguos asentamientos existentes en la comarca desde muy antiguo, destacando las actividades mineras y ganaderas como la base de su economía. Fue enclave de importancia en la época romana, algo constatado en el yacimiento de Majadaiglesia, urbe con relevante papel en la agricultura, ganadería y minería.

La riqueza mineral de los Pedroches ha sido aprovechada por las civilizaciones que han habitado en ella. Buena parte de la cañada real soriana se funde con la vía romana del Azogue, por dónde se llevaba el mercurio desde las minas de Almadén hasta Córdoba, la entonces capital de la Bética. A tener en cuenta las minas del Soldado y las Morras, que dieron esplendor y riqueza a la comarca en las primeras décadas del siglo $\mathrm{XX}$. 


\section{LOS PEDROCHES EN LA ÉPOCA MODERNA}

Todos los pueblos que habitaron este territorio dejaron su impronta de una $u$ otra manera, permitiéndonos en la actualidad el poder disfrutar de los monumentos, paisajes o tradiciones que han pervivido en el territorio.

Su aprovechamiento económico a lo largo de los siglos, nos ha proporcionado un rico patrimonio arquitectónico rural y monumental, que se muestra a través de norias, chozas, fuentes, abrevaderos diseminados por la dehesa, además de ermitas, casas con escudos blasonados, torres y castillos que dominan los flancos de la comarca al norte, oeste y centro, siendo el granito la materia prima que sobrevive al paso del tiempo.

Tras la reconquista, ya en el siglo XIII, se produjo una reorganización administrativa que dio lugar a la aparición de tres subcomarcas, que hoy día constituyen rutas de carácter cultural afianzadas en el territorio.

La ruta de las Siete Villas, conformada por los municipios de Dos Torres (Torremilano), Torrecampo, Pozoblanco, Villanueva de Córdoba, Alcaracejos y Añora, y encabezados por Pedroche, ofrece al visitante un interesante patrimonio natural e histórico artístico. Estas villas de realengo dependieron siempre de la jurisdicción de Córdoba, y pudieron hacer frente a los grandes señores gracias a la unidad que demostraron, manteniendo un único término juridisccional hasta 1909, así como el aprovechamiento comunal de grandes extensiones de dehesa, como la de la Jara, la de Ruices o la dehesa de las Navas del Emperador. El gestionar y compartir el principal recurso natural marcó los vínculos políticos de estas poblaciones. El concejo se reunía en la ermita de Piedrasanta, donde hasta el año pasado podían verse los bancos donde se sentaban los representantes de los concejos. En el año 2013 se inauguró el Centro de Interpretación de las Siete Villas de los Pedroches ubicado en el mismo paraje donde se encuentra la ermita, y construido con el propósito de difundir la historia común de las Siete Villas, desde el siglo XIII hasta el XIX, dándonos a conocer su origen, su organización política e institucional y la cultura tradicional surgida de ella.

El pasado medieval de la villa de Pedroche queda patente en su entramado urbano, cuyas calles en su día formaron parte de la antigua judería. Como prueba de su pasado de esplendor han quedado ermitas como la de San Sebastián, la iglesia conventual de la Inmaculada Concepción, monasterio fundado en el siglo XVI o Santa María del Castillo.

Torrecampo fue una de las poblaciones surgidas al amparo de Pedroche, cuando sus habitantes huyeron de la peste que asolaba el pueblo. De origen medieval, sigue manteniendo viva en la actualidad su dedicación a la agricul- 


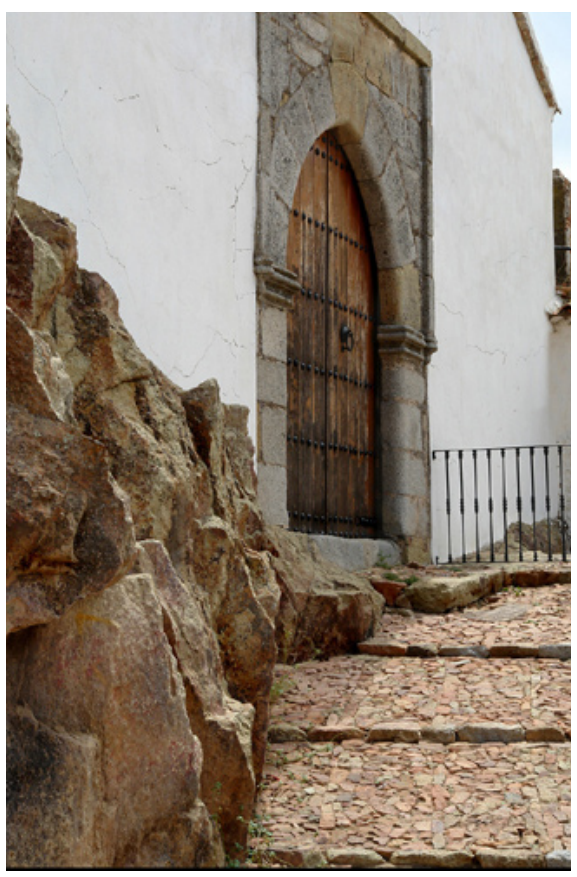

Iglesia del Salvador. Pedroche

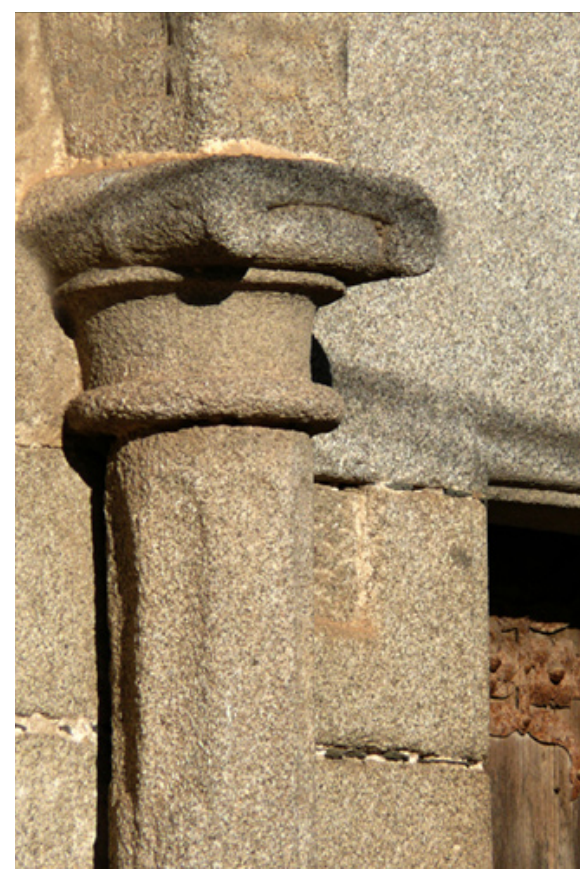

Posada del Moro. Torrecampo

tura y a la ganadería, conservando los rasgos de lugar de paso de las rutas de la trashumancia.

Los orígenes de Dos Torres se remontan a los siglos XIV y XV, ya que fue en éstos en los que surgieron las dos villas que dieron lugar con el paso del tiempo al actual municipio: Torremilano y Torrefranca. Fue el 11 de diciembre de 1839 cuando el general Espartero decretó la fusión en un sólo municipio de las dos villas: Dos Torres. Estas villas fueron cuna de nobles e hidalgos, rango social que ha quedado patente a través de los siglos en sus monumentos y casas solariegas de portadas y escudos blasonados, conservando uno de los más importantes legados arquitectónicos de los existentes en la zona.

Es probable que el nacimiento de Villaralto a comienzos del siglo XV se relacione con el pago de viñas y tierras de pastoreo de gentes de Torremilano, que construyeron varias chozas para cuidar más de cerca sus heredades, surgiendo como núcleo permanente a finales del siglo $\mathrm{XV}$ o principios del $X V I$, reconocido en sus inicios como barrio dependiente de Torremilano. Cabe destacar la existencia de un museo del Pastor, institución creada con la finalidad de proteger, conservar y difundir el patrimonio etnológico relacionado con la vida pastoril de la comarca, y especialmente de la localidad.

El puerto del Calatraveño, insignia y emblema de la zona, marca la entrada natural al sur de los Pedroches. Singulares paisajes ofrecen los ríos Cuzna y Guadalbarbo. Vigilado por la Chimorra, inquebrantable testigo de un esplen- 
doroso pasado minero, Alcaracejos aparece como testigo del paso del visitante por importantes vías de comunicación que contrastan con el granito y cal de sus calles. En el término tienen cabida los cuatro paisajes fundamentales de los Pedroches: cereal, zonas de olivar, dehesas ganaderas y monte mediterráneo.

El término "añora" tiene su origen en la palabra árabe naura, que significa noria. Según los estudiosos, el término hace referencia a la noria de una huerta que había en las cercanías del lugar que, actualmente, ocupa el municipio. Y fue en torno a la huerta citada donde se fueron agrupando los habitantes primeros de la villa.

Como segundo gran espacio histórico, que conforma parte del territorio de los Pedroches, encontramos la ruta del Condado de Santa Eufemia, que comprende los municipios de Santa Eufemia, El Guijo, El Viso y Torrefranca. Surgido en 1293, cuando el concejo cordobés hace donación a Fernando Díaz Carrillo de la villa de Santa Eufemia, lo que propició la creación de éste Condado, ya que por sus tierras transcurría una de las principales vías de comunicación en el transporte de mineral desde Almadén hasta Córdoba y Sevilla, la denominada ruta del Azogue.

Santa Eufemia ha sido a través de los siglos puerta natural de entrada a los Pedroches. Su carácter fronterizo le ha otorgado igualmente una privilegiada posición estratégica. El intenso pasado medieval de Santa Eufemia todavía se aprecia, además de en la iglesia, en la propia configuración urbana de la población y particularmente en su cerco de murallas. Uno de los elementos patrimoniales más singulares de Santa Eufemia es el castillo de Miramontes, antigua fortaleza musulmana desde la que se pueden contemplar los paisajes de Extremadura, Castilla la Mancha y Andalucía.

Del esplendor romano de esas tierras dan buena prueba los restos arqueológicos aparecidos en la zona de Majadaiglesia, en el municipio de El Guijo, un área de fuerte tradición mariana como demuestran documentos castellanos del siglo XII. En este enclave conocido como "El Soto" se encuentra también la ermita de la Virgen de las Cruces, a 6 kilómetros del casco urbano. Construida sobre el cordel de la Mesta; en la sacristía se puede contemplar un baptisterio de origen paleocristiano.

La primera mención documentada de El Viso data del año 1410, donde aparece con el nombre de Casas de Don Adame, cuyo origen pudo deberse al establecimiento de unas ventas en la ruta que comunicaba Castilla con Andalucía. Su término ha sido siempre paso obligado en el "camino del Azogue". Bajo la jurisdicción del condado de Santa Eufemia, hasta el siglo XIX, El Viso se convirtió en la localidad más poblada del

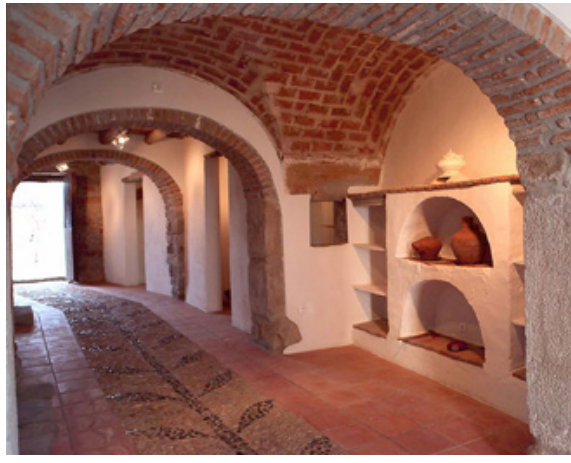

Museo del Pastor. Villaralto

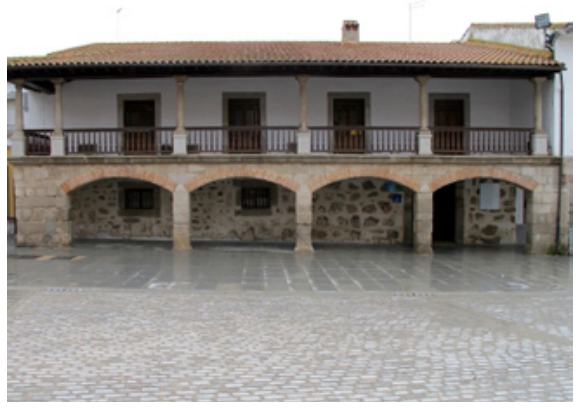

Plaza porticada. Dos Torres

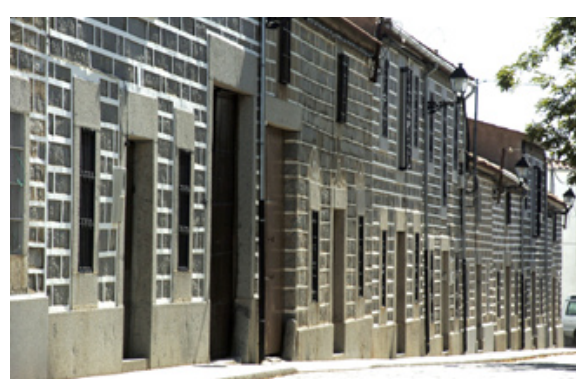

Fachadas de tiras. Añora

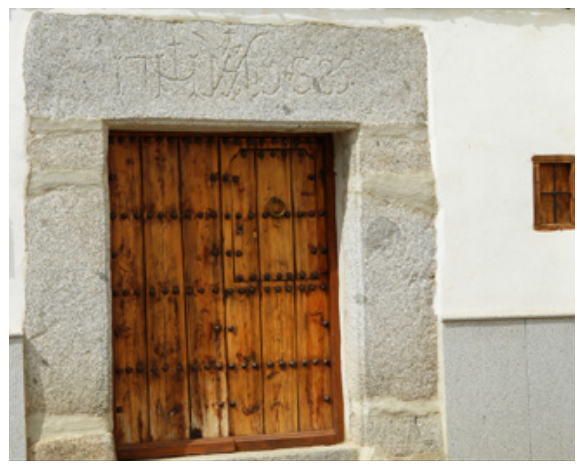

Dintel de granito. Alcaracejos citado señorío. El Viso también conserva en su término el conocido como 


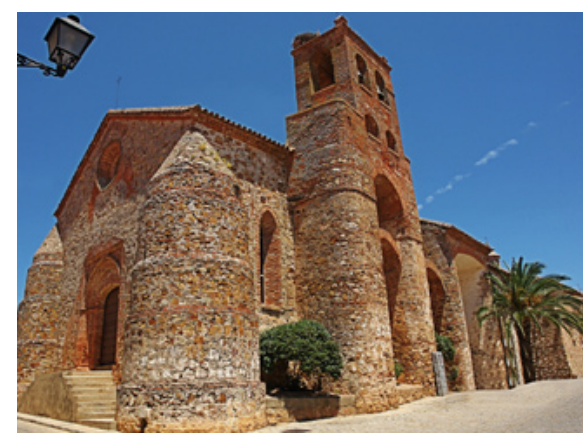

Parroquia de Ntra. Sra. De la Encarnación. Santa Eufemia

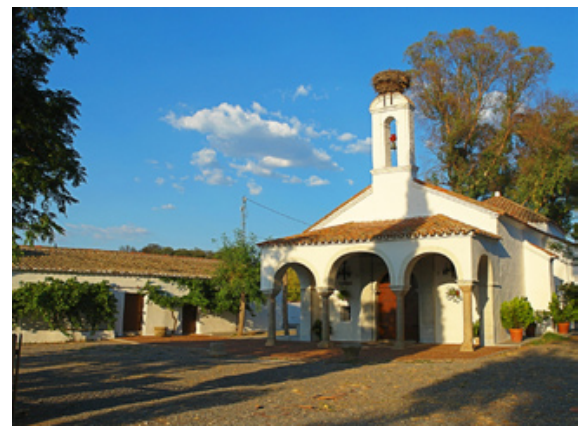

Virgen de las Cruces. El Guijo

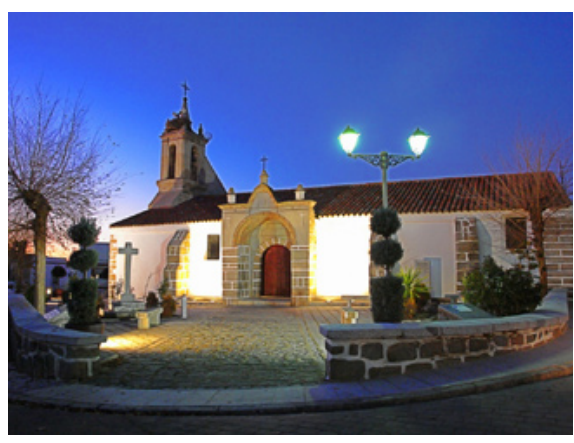

Parroquia de Santa Catalina. Fuente la Lancha

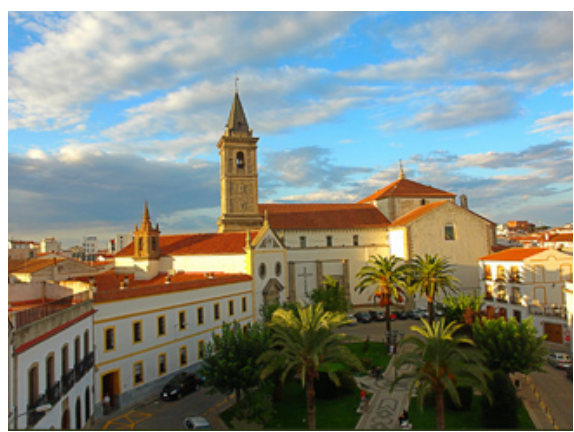

Parroquia de Santa Catalina. Pozoblanco

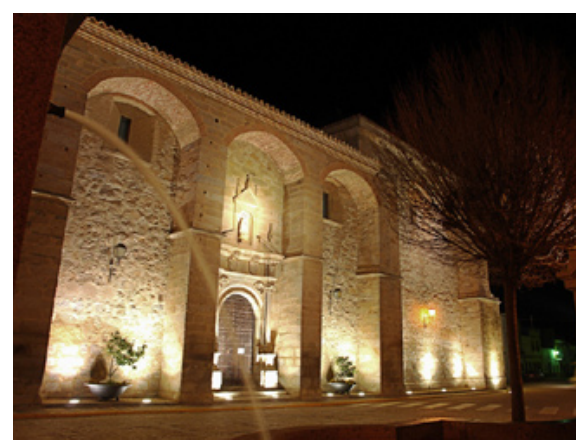

Convento de las Concepcionistas. Hinojosa del Duque

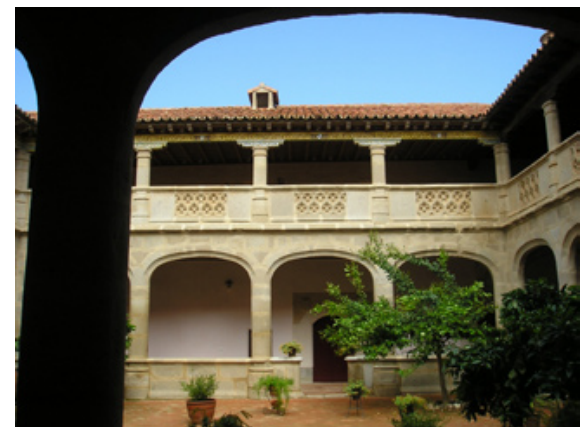

Convento de Santa Clara. Belalcázar

castillo de Madroñiz, de origen musulmán, bien conservado y visitado habitualmente por cazadores.

El condado de Belalcázar, se originó en 1445, cuando Juan II concedió al entonces maestre de la Orden de Alcántara, las Villas de Gaete (Belalcázar) e Hinojosa del Duque; a éste condado también pertenecían las villas de Villanueva del Duque y Fuente La Lancha.

La comarca de los Pedroches no deja indiferente al visitante ante la riqueza monumental escondida en las callejas de sus pueblos, construcciones de dimensiones espectaculares como el Convento de Santa Clara de Belalcázar, segundo monumento histórico-artístico tras la Mezquita de Córdoba, o el imponente castillo de los Sotomayor, también en Belalcázar, guardián de los Pedroches desde la Serena, del que destaca su torre del homenaje de $45 \mathrm{~m}$ de altura.

Hinojosa del Duque ofrece uno de los conjuntos monumentales más notables del norte de la provincia de Córdoba. Vinculada a la casa condal de Belalcázar desde 1444, se convirtió en el municipio más importante del citado señorío. Fue durante siglos parada obligada para los pastores trashumantes y centro de las ferias de ganado, de lo que es testigo su fuente del Pilar. Villanueva del Duque se creó a finales del siglo XV. Su primitivo 
nombre fue Villanueva del Marqués, que cambió por el actual después que en 1518 se vinculase al condado de Belalcázar el ducado de Béjar. La intensa actividad minera que se desarrolló en el siglo XIX en su término dio lugar a la creación de poblados con una importante población y actividad económica.

Aldea de Hinojosa del Duque hasta 1820 cuando consiguió el título de villa, Fuente la Lancha, constituye el municipio con menor extensión de la comarca, lo que siempre ha limitado su extensión. El origen del topónimo "lancha" puede proceder del nombre dado a las piedras de granito de forma plana que afloran a la superficie.

\section{DEHESAS E IBÉRICO}

La última de las rutas que podemos destacar en los Pedroches, y que constituye hoy en día uno de los principales recursos de la población, es la denominada ruta del Ibérico. La importancia ganadera de los Pedroches se desarrolla desde la época árabe cuando recibió el nombre de Fash al-Ballut (llano de las bellotas), y que constituye una de las mayores riquezas de la zona: el jamón ibérico de bellota.

El pastoreo de los cerdos ibéricos en la dehesa configura una estampa única durante la época de montanera a finales de otoño, pasando por las matanzas de las que se obtienen los jamones y paletas de ibérico que se destacan en su gastronomía, lo que constituye uno de los mayores reclamos turísticos de la comarca.

En los últimos tiempos se están potenciando estos rituales culinarios como atractivo para el turismo activo, haciendo partícipe al visitante de este proceso de elaboración artesanal de uno de los platos por excelencia de la gastronomía de los Pedroches.

Recorriendo la ruta del Ibérico podremos conocer el entorno donde se cría el cerdo ibérico, la diversidad de los paisajes que integran la ruta y la actividad y patrimonio de sus pueblos. Desde Hinojosa y Alcaracejos, Ilegando a Pozoblanco y Villanueva de Córdoba, y finalizando en Cardeña o Conquista, recorremos los pueblos en los que de forma más significativa se ha desarrollado tradicionalmente la producción e industria del ibérico.

Su posición geográfica en el centro de los Pedroches ha convertido a Pozoblanco en la capital económica y administrativa de la comarca. Su patrimonio está lleno de elementos originales que guardan una belleza heterogénea dentro de su sencillez, siendo denominador común de todos ellos el granito. La personalidad emprendedora de su gente no está reñida con el 


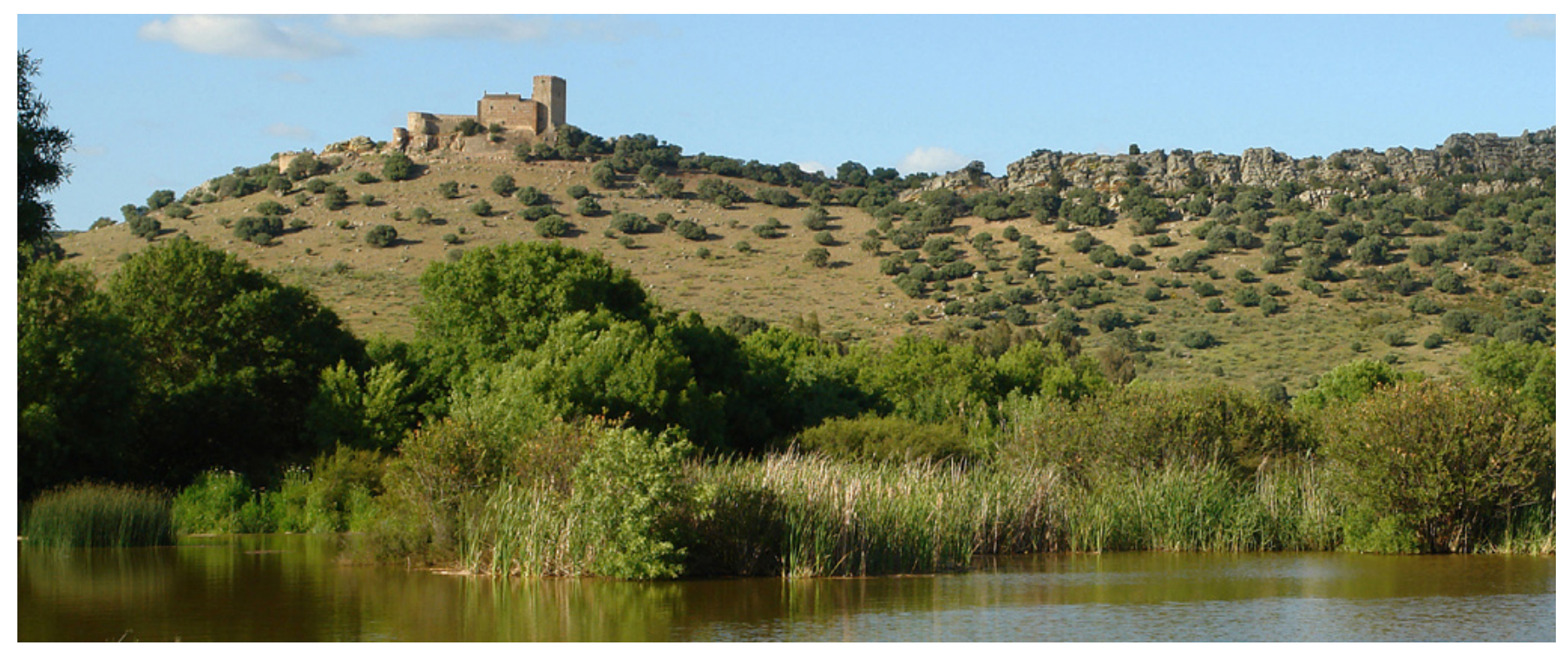

Castillo de Madroñiz. El Viso

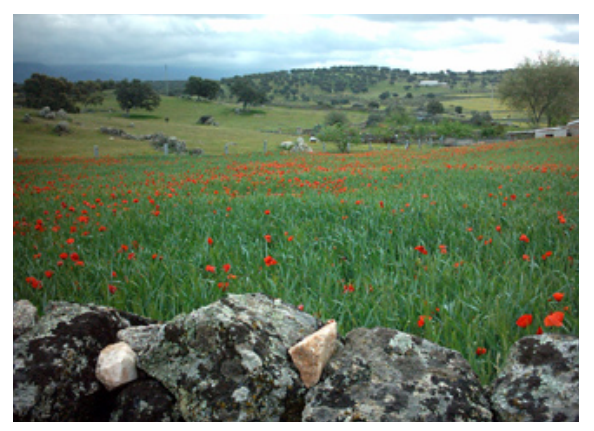

mantenimiento del sabor a pueblo de la sierra que ha sabido preservar su entorno natural, donde la dehesa de encinar en la que pasta el cerdo ibérico da paso a la abruptosidad y riqueza biológica del ecosistema del río Cuzna.

El desarrollo ganadero pasa a ser la principal fuente de riqueza de la localidad de Villanueva de Córdoba; muestra de ello es la extensa dehesa que la rodea, que es considerada el bosque de encinar más extenso de Europa, y donde se ceban los cerdos ibéricos, cuyos productos derivados -jamón, cecinas,...- encuentran en este municipio el lugar perfecto para su curación.

Paredes de granito. Conquista

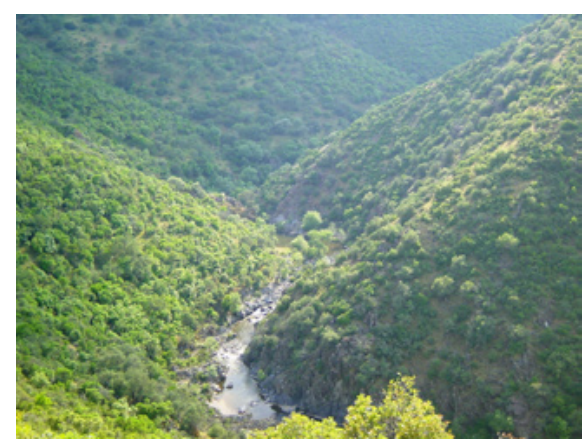

Río Yeguas. Cardeña
El municipio de Conquista nació en torno al camino de la Plata, que unía Córdoba con Toledo, aunque no alcanzaría su esplendor hasta finales del siglo XIX y en las primeras décadas del XX, debido a las explotaciones mineras y a la llegada del ferrocarril. Las espesas y frondosas dehesas de encinar en sus alrededores dan muestra del marcado carácter ganadero de esta localidad.

El municipio de Cardeña presume de contar con uno de los paisajes mejor conservados de Sierra Morena. No en vano, la mayor parte del Parque Natural de Cardeña-Montoro se ubica en su término municipal. Situada en uno de los caminos utilizados para llegar a Toledo desde Córdoba, diversos privilegios reales dieron origen a una serie de ventas en esta zona, circunstancia que explica el nacimiento de Cardeña, Azuel y Venta del Charco. 


\section{BIBLIOGRAFÍA}

- Domínguez, F. J. (2008) Dehesas y la trashumancia en el Sur: Las fronteras de Andalucía. Dos Torres. Córdoba: Asociación ADROCHES para el Desarrollo Rural de la Comarca de Los Pedroches, 2008

- Memoria ADROCHES 2000-2008. Grupo de Desarrollo Rural de Los Pedroches, 2009

- LUNA, M.; LUCAS, M. (2006) Arquitectura tradicional y entorno construido. Proyecto Identidades II. Asociación ADROCHES para el Desarrollo Rural de la Comarca de Los Pedroches, 2006.

- VAlLE Buenestado, B. (1985) Geografía Agraria de Los Pedroches. Córdoba: Diputación Provincial de Córdoba, 1985

- CARPIO DUEÑAS, J. B. (2000) La tierra de Córdoba. El dominio jurisdiccional de la ciudad durante la Baja Edad Media. Córdoba: Publicaciones de la Universidad de Córdoba y Obra Social y Cultural CajaSur, 2000 


\section{ph

\section{La dehesa de los Pedroches: patrimonio natural y cultural}

Centro de Interpretación de la Dehesa

URL de la contribución <www.iaph.es/revistaph/index.php/revistaph/article/view/3545>

\section{RESUMEN}

La comarca de los Pedroches, con 17 pueblos en $360 \mathrm{~km}^{2}$, es sin duda uno de los espacios naturales más interesantes de toda Andalucía. Forma la dehesa más densa de toda Europa, dehesa que, a través de los siglos, ha conformado una cultura y una forma de relación entre el hombre y el medio ambiente muy característica y, sin ninguna duda, sostenible.

Como lugar de interpretación de este medio surge en 2010, en Villanueva de Córdoba, el Centro de Interpretación de la Dehesa, en una casa del siglo XIX, rehabilitada, y que mantiene las características arquitectónicas propias de los Pedroches, techos altos terminados en bóveda de arista, pasillos anchos, varios cuerpos de casa, y como material constructivo el granito, que se encuentra en espectaculares afloraciones por toda la dehesa.

Otro elemento patrimonial que define la dehesa de los Pedroches son sus paredes de piedra, construidas tradicionalmente sin argamasa y con bloques de tamaños distintos que reciben nombres diferentes: catana, codal, barda, ripio. La función de estas paredes es doble, por una parte definir la propiedad y por otra evitar que los animales circulen libremente de un lugar a otro de la dehesa.

El Centro de Interpretación de la Dehesa explica diversos aspectos de la dehesa, sus características naturales, los usos y oficios que ha propiciado a lo largo de la historia, la cultura peculiar muy influenciada por la proximidad extremeña y castellana y la economía basada fundamentalmente en una ganadería extensiva que se centra en tres especies fundamentales: el cerdo ibérico, la oveja y la vaca.

\section{Palabras clave}

Andalucía | Centro de Interpretación de la Dehesa | Córdoba (Provincia) | Dehesas | Patrimonio cultural | Patrimonio natural | Valle de los Pedroches (Córdoba) | Villanueva de Córdoba | 


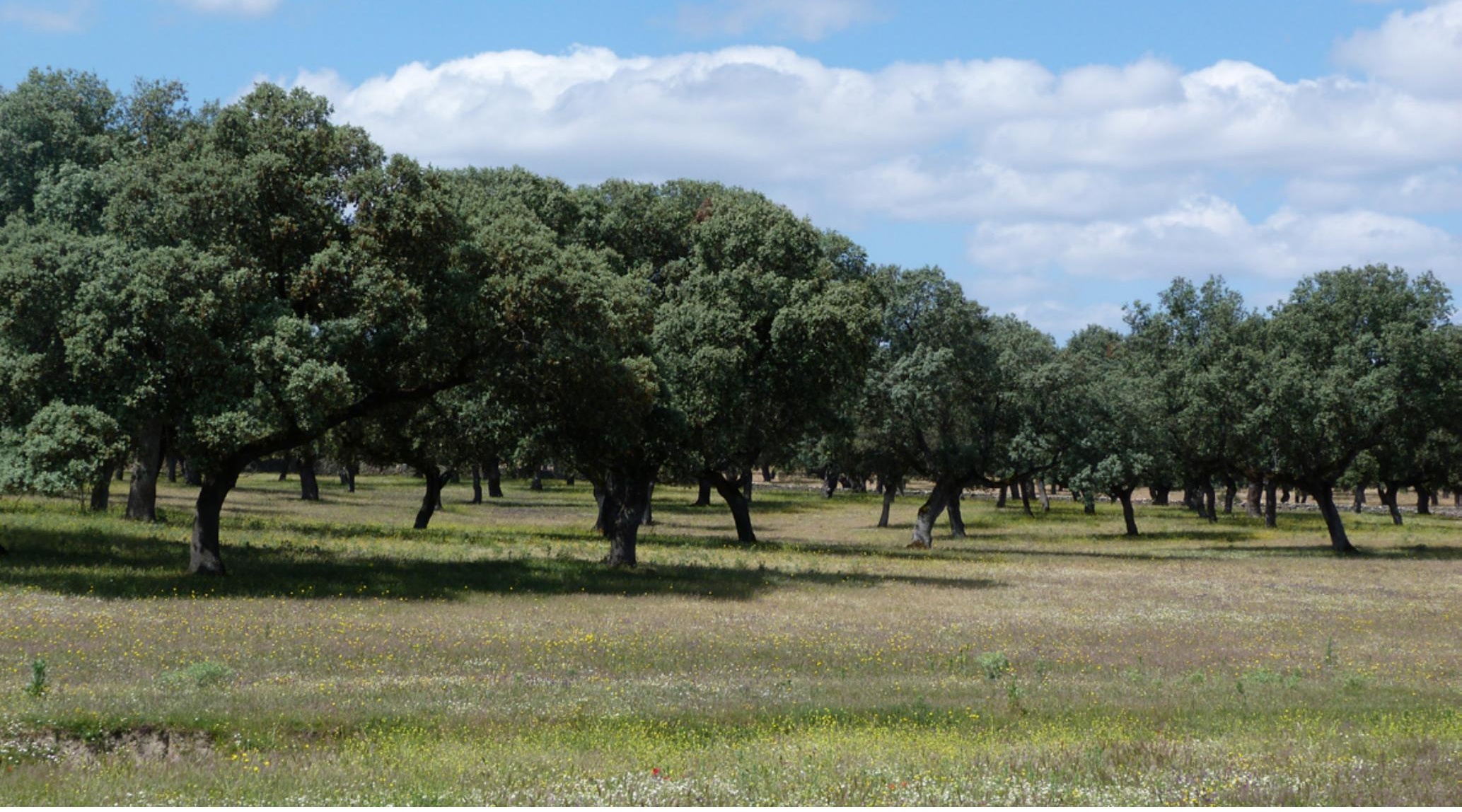

Dehesa | foto Oficina de Turismo del Ayuntamiento de Villanueva de Córdoba (para todas las imágenes del artículo) 
Medio natural antropizado. Bosque medi-terráneo modificado por el hombre para asegurarse su subsistencia.

Centro de Interpretación de la Dehesa, recreación bodega y patio del centro

No cabe duda que si hay un elemento que define a toda la comarca de los Pedroches, éste es la dehesa ${ }^{1}$. Espacio natural creado por el hombre, uno de los mayores exponentes de sostenibilidad y equilibrio entre lo natural y lo humano.

Para conocer este ecosistema desde 2010 se puede visitar, en Villanueva de Córdoba, ubicada en el corazón de la dehesa más poblada de Europa, en los Pedroches, el Centro de Interpretación de la Dehesa. Aquí podemos acercarnos a aspectos tan diversos como el entorno natural, la cultura, la economía, la sociedad, que han creado un espacio propio y característico.

Ubicado en una casa del siglo XIX rehabilitada, que responde a las características arquitectónicas de la comarca pedrocheña: varios cuerpos, en uno de los cuales se situaba la cocina, que calentaba toda la vivienda; techos altos en la planta baja definidos por bóvedas de arista que respondían a una doble funcionalidad, estética y arquitectónica ya que este tipo de arista permite soportar mejor el peso del piso superior, lugar destinado a almacén de grano y matanza; pasillo muy ancho que permitía la entrada de los animales de carga que se llevaban hasta la cuadra situada en la parte posterior de la casa, donde también solía estar el pajar, el huerto y una cocinilla.

Como material se utiliza tanto el granito como la pizarra, trabadas con una mezcla de barro o cal y arena, para todos los muros perimetrales. Las estancias internas se delimitan con ladrillos de barro cocido. Las puertas, ventanas y zócalos de la fachada suelen ser de sillares encalando el resto. Las cubiertas son a dos aguas, hechas con vigas de encina, y con otras vigas menores
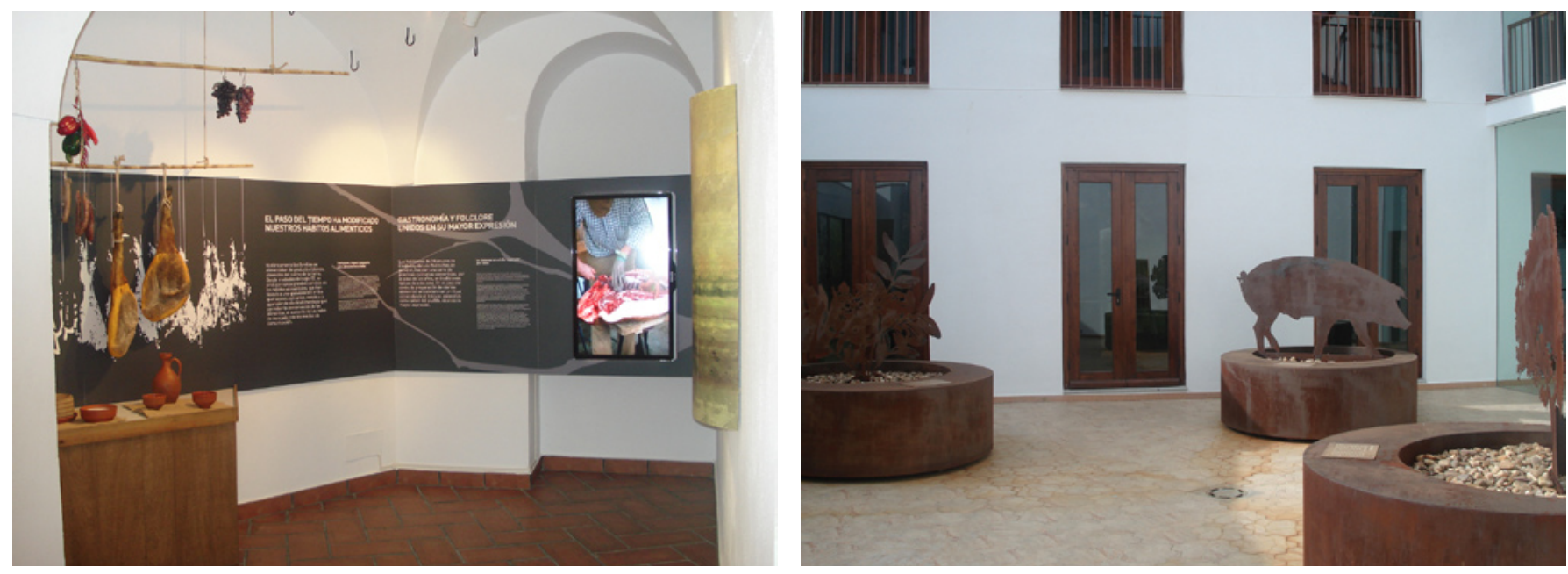
cruzadas transversalmente a las principales, de tablones de madera o "tiguillos" de madroño. Todo se cubre después con teja árabe.

El Centro de Interpretación de la Dehesa ${ }^{2}$ ofrece un recorrido por la historia y los usos de la dehesa a través de paneles explicativos y el uso de las nuevas tecnologías. Los espacios que encontraremos en el centro son los siguientes:

$>$ El lugar: donde se contextualiza la dehesa, dentro de la comarca de los Pedroches, las características humanas, la flora y fauna.

> La raíz: los orígenes. Se hace un repaso por la dehesa desde su origen y la transformación que ha sufrido a lo largo de los siglos por la mano del hombre.

$>$ El tronco: en esta parte expositiva, centrada en el patio, aparece todo lo referente a la flora, tronco de la encina, espinas, flores, bellota, cercado de piedra.

> Las ramas: zona dedicada al visionado de un documental en el que durante 15 minutos se expone la historia, usos, folclore, trabajos, gastronomía, etnología, etc.

> Los frutos: esta última parte se ha destinado a explicar el folclore, la gastronomía, el trabajo, la artesanía que la dehesa ha generado a través de los siglos y que en algunos casos aún perduran.

El proceso histórico de la comarca de los Pedroches ha condicionado de forma definitiva la geografía de las dos subcormarcas pedrocheñas.
2

Más información: http://www.andalucia.org/es/ turismo-cultural/visitas/cordoba/otras-visitas/ centro-de-interpretacion-de-la-dehesa/
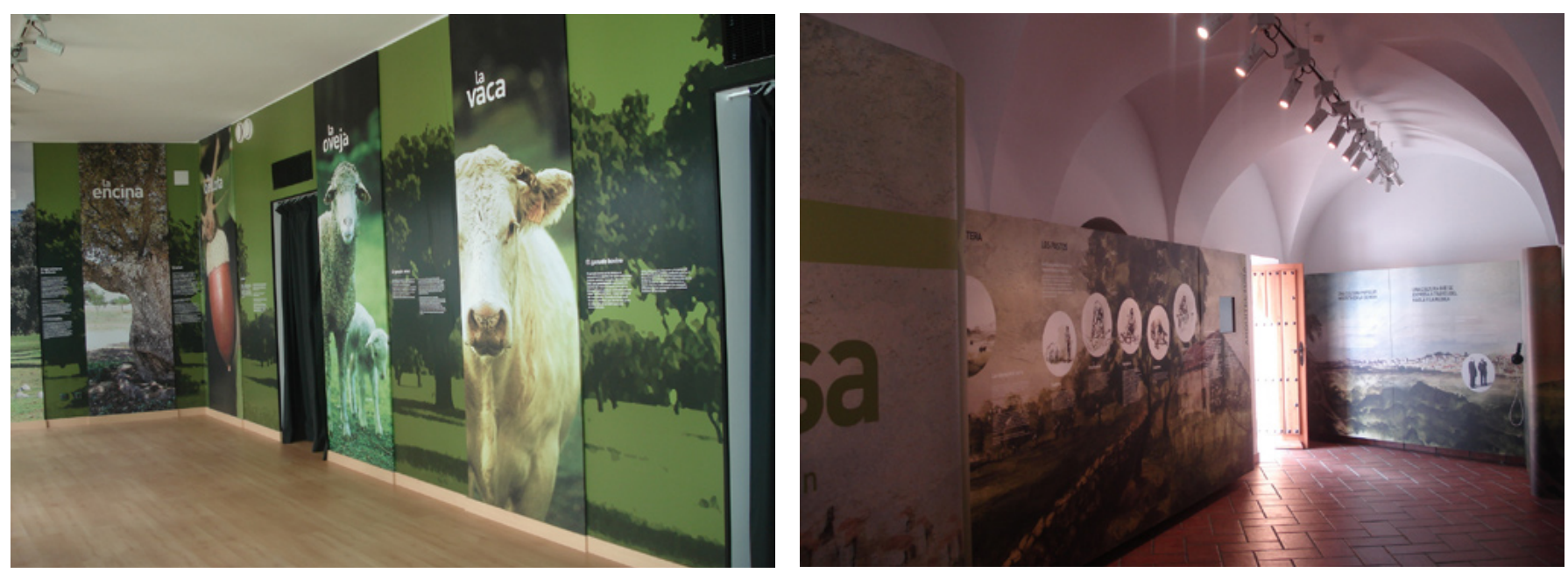
3

Uso del bosque con fines económicos, tala, producción de carbón, picón, etc.

4

Constructores de las paredes de piedra que delimitan las fincas en la dehesa.
Con la creación del señorío de Santa Eufemia en 1293 y el de Belalcázar en 1444 , la zona occidental quedó configurada como zona de señorío, y la subcomarca centro-oriental permaneció como zona de realengo. Esta división jurisdiccional propició notables diferencias paisajísticas.

En la occidental, las parcelas se configuraron como grandes latifundios señoriales, procedentes de la usurpación y el adehesamiento indebido. En la subcomarca centro-oriental predominó la propiedad pública, conviviendo con la privada y, aunque también se produjeron usurpaciones, su incidencia fue mucho menor.

Las desamortizaciones del los siglos XIX y XX, ahondaron en la transformación del bosque mediterráneo, con el traspaso de tierras forestales no cultivables a manos privadas, que inmediatamente se roturaron para obtener mayores beneficios de ellas: venta de carbón, leña, pastoreo, tala y cultivo.

Sin embargo en determinadas zonas, el bosque se vio alterado sólo en los estratos inferiores. Las labores agrícolas y silvícolas ${ }^{3}$ practicadas de una forma inteligente y racional, generaron un bosque equilibrado, conservándose una importante masa de arbolado constituido por encinas, alcornoques y quejigos: la dehesa. A través de esta asociación entre naturaleza e inteligencia, el ser humano ha llevado a cabo un aprovechamiento integrado de suelo y vuelo, es decir, la búsqueda de beneficio en los pastos y las hierbas, necesarias para la alimentación del ganado, y en consecuencia para la obtención de todos los productos derivados, de los arbustos y los árboles, para la extracción de madera y carbón, y de los frutos, como la bellota, para el consumo directo.

El termino "dehesa" proviene del castellano defensa, que denominaría a aquellos terrenos acotados para impedir el pastoreo de ganado trashumante mesteño. La dehesa es por tanto una creación humana a partir de un bosque de encinas primitivas.

El paisaje adehesado de los Pedroches está formado por cercados de piedra realizados por los parederos ${ }^{4}$. Se trata de muros de aproximadamente $30 \mathrm{~cm}$ de anchura y una altura de 1,50 metros. La creación de estas cercas se realizó para preservar los sembrados de los animales, así como para reafirmar la propiedad. Los parederos trabajan en cuadrillas empleando mampuestos que reciben nombres diferentes dependiendo de su tamaño y función: las catanas son piedras de gran tamaño y formas regulares, normalmente empleadas en la base; las codales, son piedras dispuestas transversalmente al eje de la pared, para romper las posibles tensiones; las bardas son las planas que se colocan en lo alto de la pared; los ripios son las pequeñas que rellenan los intersticios. 


\section{BIBLIOGRAFÍA}

- VALLE BUENESTADO, B. (1985) Geografía agraria de Los Pedroches. Córdoba: Excma. Diputación Provincial de Córdoba, 1985

- VALLE BUenestado, B. (1978) Villanueva de Córdoba. Estudio geográfico. Córdoba: Excma. Diputación Provincial de Córdoba, 1978

- ALONSO MORALES, M. (2007) Comarca de Los Pedroches, Córdoba, Andalucía. En LUNA, M.; LUCAS, M. (eds.) Arquitectura tradicional y entorno construido. Murcia: Quaderna, 2007, pp. 331-373 


\section{p̈h

\section{Rituales y festejos en el valle de los Pedroches. Imágenes simbólicas de un territorio de frontera}

Juan Agudo Torrico | Departamento de Antropología Social, Universidad de Sevilla

URL de la contribución <www.iaph.es/revistaph/index.php/revistaph/article/view/3515>

\section{RESUMEN}

Históricamente la comarca del valle de los Pedroches ha sido un territorio de frontera interior, entre las tradiciones culturales castellanas y andaluzas. Es por ello que muchas de las expresiones culturales que caracterizan a la comarca, mientras que son compartidas con los territorios manchegos y extremeños circunvecinos, apenas si se encuentran en otros lugares de Andalucía.

En semejante contexto, los rituales que perviven en la comarca constituyen un ejemplo relevante del mencionado pasado y proceso histórico. El análisis que realizamos parte de este hecho para centrarnos en aquellos aspectos que consideramos que dotan de una mayor singularidad etnográfica a su sistema ritual: el papel que han jugado las numerosas ermitas y santuarios en la configuración del territorio simbólico; significación de sus romerías como ejes centrales de este sistema ritual; y particularidades del modelo de hermandades militares que ha caracterizado al sistema organizativo y procesos rituales en muchos de sus poblaciones.

\footnotetext{
Palabras clave

Actividades de interés etnológico | Andalucía | Antropología | Córdoba (Provincia) | Festividades cristianas | Influencia cultural | Patrimonio cultural | Rituales festivos | Valle de los Pedroches (Córdoba) |
} 


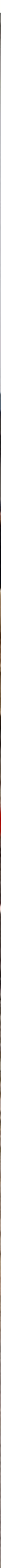

Santa Lucía en Villanueva del Duque | foto Fondo Gráfico IAPH 
La comarca que hoy conocemos como valle de los Pedroches ha sido a lo largo de buena parte de su historia una tierra de frontera interior. $Y$, por lo tanto, de territorio de encuentro, de intercambio de expresiones y prácticas culturales. Y así sigue siendo sentida hoy en día, depositaria de unos rasgos culturales que se fueron conformando básicamente en el trascurso de la Baja Edad Media; cuando, al tiempo que dejaba de pertenecer al AlÁndalus, se afianzaba como límite de los nuevos reinos cristianos que, con el paso del tiempo, terminarían por convertirse en la España de las autonomías del presente. De este modo, el valle de los Pedroches se convierte en la comarca más septentrional de Andalucía, penetrando como punta de lanza entre Extremadura y Castilla la Mancha; y, en contrapartida, también se transforma en el límite meridional de estos otros territorios.

En la práctica, historia e imaginarios colectivos han concluido por dotar al valle de los Pedroches de un notable particularismo cultural, con lo que su actual adscripción jurídico-administrativa a la autonomía andaluza contrasta con un sentimiento de identidad en el que aflora, y se reseña con frecuencia, la fuerza que siguen teniendo los rasgos culturales identificados con unas no menos imaginarias culturas extremeña y manchega: habla, arquitectura, gastronomía, paisajes culturales, música,...

Sus rituales vendrían a ser un magnífico ejemplo de esta paradoja de cruces de identidades. Como después veremos, hay rituales y sistemas organizativos que no rebasaron los límites meridionales de la comarca; pero en otros aspectos poco o nada diferencia las formas de expresión festivo-ceremoniales que encontramos en la comarca, de los rituales que podemos observar en cualquier otro lugar de Andalucía, o de las dinámicas de transformación que les afecta.

Así, hoy en día, en el conjunto de las diecisiete poblaciones que se distribuyen por su territorio, encontraremos un complejo y rico sistema ritual. La

Auto de los Reyes Magos en El Viso

| fotos Fondo Gráfico IAPH
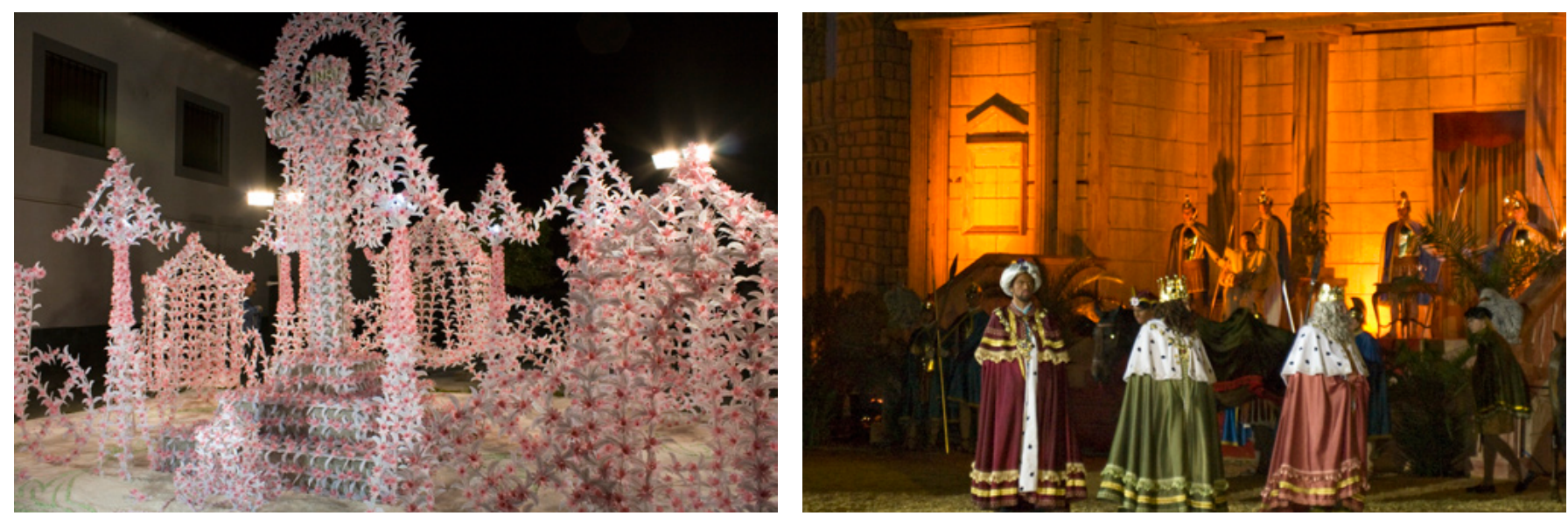
vida y economía de sus pobladores siempre ha estado centrada en la actividad agroganadera. Por ello, como en tantos otros lugares, su ciclo festivo va a estar pautado por el ritmo de las estaciones, acompasando los tiempos de descansotrabajo al ritmo de las labores en el campo y benignidad climatológica.

Sin que nos podamos detener en un análisis más pormenorizado, las fiestas de invierno, entroncadas con tradiciones más castellanas que andaluzas, están bien representadas por los candelorios que se celebran en las calles de buena parte de sus poblaciones con motivo de la Virgen de la Candelaria (en torno al dos de febrero), recuperados con vigor desde las últimas décadas del siglo XX. También son numerosos y diversos los festejos que celebran San Sebastián, advocación que llegó a contar con ermitas en al menos siete de sus localidades. Y como referencia emblemática de la propia comarca, en El Viso se sigue representando uno de los más antiguos autos sacramentales de los que tenemos noticia, El auto de los Reyes Magos, con una puesta en escena en la que se implican buena parte de sus vecinos. Y, de tener que seleccionar algún otro ritual que destaque por su singularidad en los fríos días de invierno, tal vez tendríamos que referirnos a la fiesta de Santa Lucía en Villanueva del Duque, con el peculiar recorrido por las calles del pueblo de su hermandad al sonido del tambor, revoloteo de su bandera, el convite abierto a todos sus hermanos limitado a la sobriedad de los puñados de garbanzo tostados que toman de la cesta y el vino compartido en la misma templaera, y, en la noche de la víspera, el enorme candelorio de aulagas que se quema frente a la casa del capitán.

Pero, como era de esperar, es en primavera y verano cuando este sistema ritual eclosione con más vitalidad. Las cruces de mayo, festejadas en diferentes poblaciones, tienen una personalidad propia en la pequeña población de Añora: las cruces de piedra que jalonan calles y plazas, así como las habitaciones de algunas de sus casas, se cubren de laboriosos y barrocos
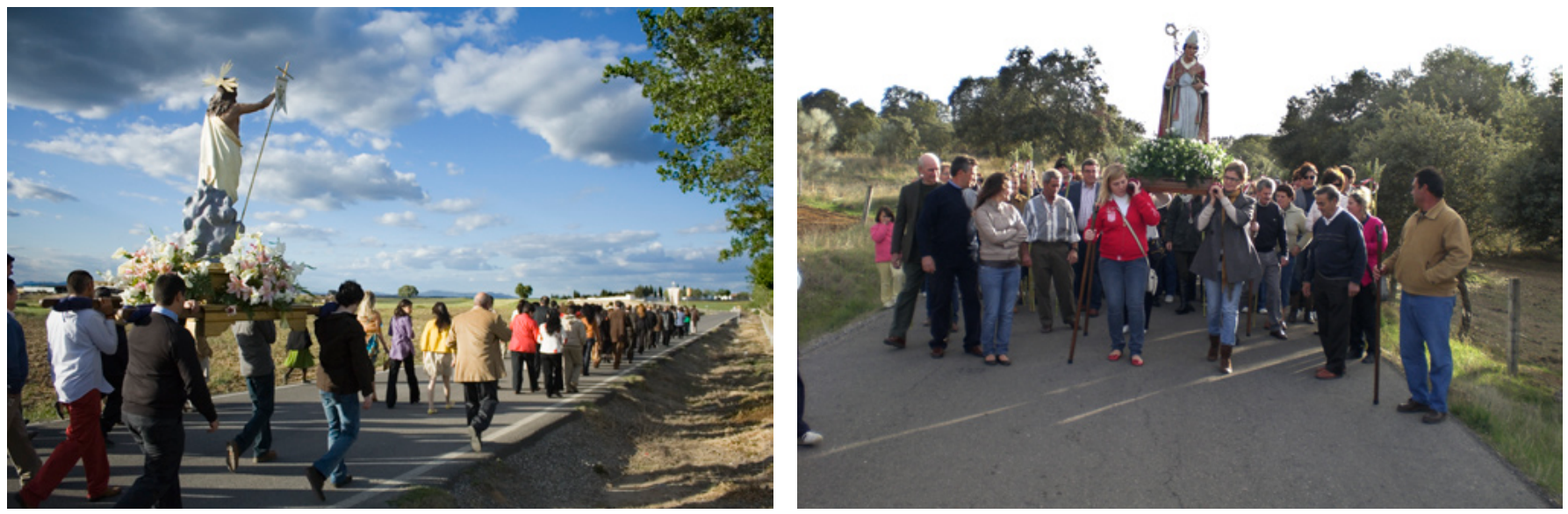
Semana Santa en Pozoblanco

| fotos Fondo Gráfico IAPH
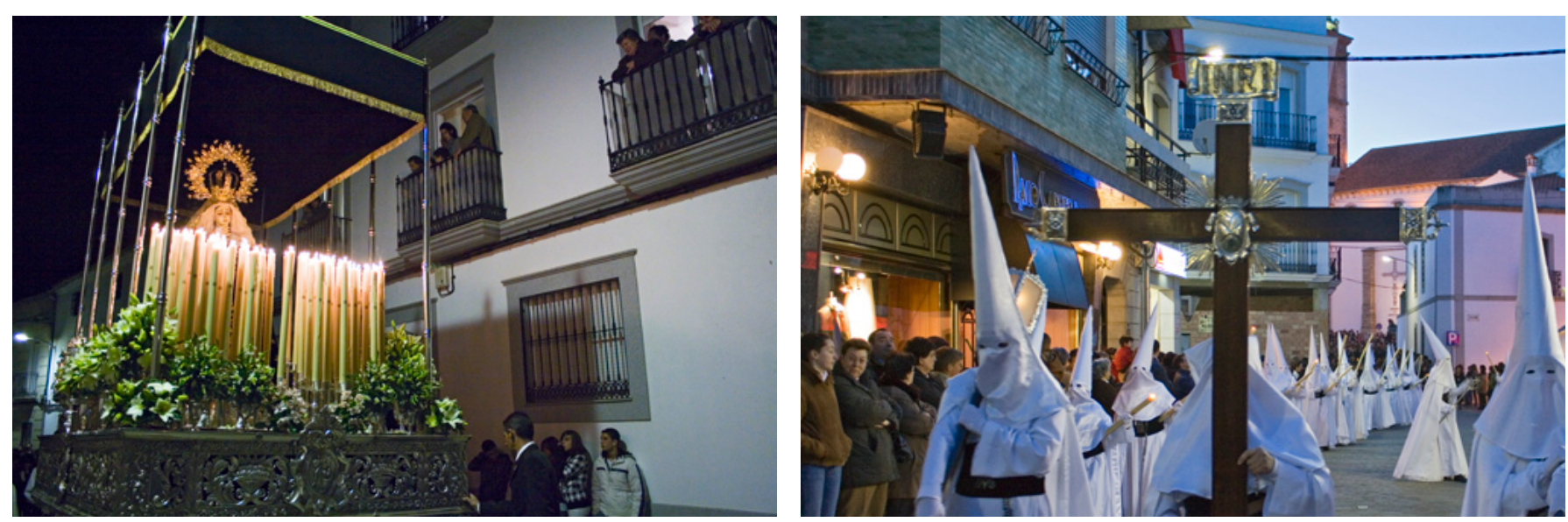

ornamentos que tienen por soporte humildes materiales de flores de papel, macetas, telas, etc.; y para conseguirlo, de nuevo la labor compartida de buena parte de su vecindario reseñando el sentido de comunidad que caracteriza a buena parte de los rituales de la comarca.

La Semana Santa, al menos de forma testimonial, no va a faltar en ninguna localidad. Si bien es en aquellas poblaciones que por razones históricas (Belalcázar) o de mayor capacidad demográfica (Hinojosa del Duque, Pozoblanco, Villanueva de Córdoba) han tenido o tienen una mayor riqueza de matices sociales, donde se manifieste con más brío en número de cofradías y peculiaridades etnográficas de algunas de sus puestas en escena: indumentaria de la cofradía del Santo Entierro en Hinojosa del Duque, soldados romanos (sayones) de Jesús Nazareno en Pozoblanco. Y el sábadodomingo de resurrección la vieja tradición de la quema de Judas se sigue practicando en Villanueva del Duque, Alcaracejos y Villanueva de Córdoba; en todos los casos son muñecos con los que de forma alegórica se invocan y destruyen aspectos negativos de nuestra sociedad, siendo especialmente cuidados y elaborados los marmotos de Villanueva de Córdoba. Pero se trata también de rituales que, lejos del inmovilismo que pudiera denotar la pervivencia de estas viejas tradiciones, han sabido adaptarse a nuevos tiempos, siendo ya un hecho generalizado el protagonismo activo de las mujeres tanto en su sistema asociativo como en los cortejos rituales; e incluso como costaleras en Hinojosa del Duque y Pozoblanco, una de las primeras en desarrollar esta práctica en la provincia de Córdoba.

Pero va a ser sobre todo en las expresiones rituales que tienen que ver con el mundo de las romerías donde el sistema ritual vigente en la comarca del valle de los Pedroches adquiere y manifieste su mayor singularidad. Creo que ninguna otra comarca andaluza ha preservado un patrimonio tan peculiar y rico como el conformado por las numerosas ermitas conservadas en 
el valle. En total existen cuarenta y siete ermitas, de las que veintiuna son rurales y otras ocho, aunque cercanas a los cascos urbanos, también se encuentran extramuros de las poblaciones. En su mayor parte datan de los siglos XIV al XVI, pero también, en un proceso compartido con otros lugares de Andalucía, se han construido en las décadas finales del s. XX (EI Viso, Fuente la Lancha, Conquista, Añora) al compás de la revitalización del significado simbólico que tienen las romerías en la cultura mediterránea, de ocasión de encuentro entre mundo rural y urbano, y de lugar y tiempo propicio para la concurrencia y autopercepción de las comunidades que las recrean.

Buena parte de estas ermitas, sobre todo las de carácter urbano o levantadas en las cercanías de los pueblos, acogen a santos encargados de proteger directamente a sus pobladores, o de contener las amenazas de epidemias y plagas que afecten a animales y cosechas: San Sebastián, San Antón, San Gregorio. Pero otras son destacados santuarios rurales que albergan a las imágenes marianas patronas de los respectivos pueblos, y dan lugar a rituales romeros de notable diversidad y riqueza etnográfica; sólo Añora y Dos Torres custodian a sus patronas en ermitas urbanas.

Cada una de las romerías que se celebran en el entorno de estas ermitas y santuarios son un mundo en sí mismas, y son muchas las razones para valorarlas y conocerlas. A la belleza de los parajes que acogen los santuarios (Virgen de las Veredas, de las Cruces, de Consolación, Santa Eufemia) hay que unir la capacidad de evocación de los caminos romeros entre cercas de piedra, sementeras y dehesas (Virgen de Luna, de Guía); las veladas de intensa convivencia comunal en los entornos de los santuarios (Virgen de la Antigua, de la Alcantarilla); o la singularidad de los procesos rituales que tienen lugar en la ermita o en los caminos (cruce del río Zújar en la romería de la Alcantarilla, juegos de banderas y descargas en las vírgenes de Luna y de Guía, engalanado de "jamugas" y "piostros" en la romería de Piedrasantas).
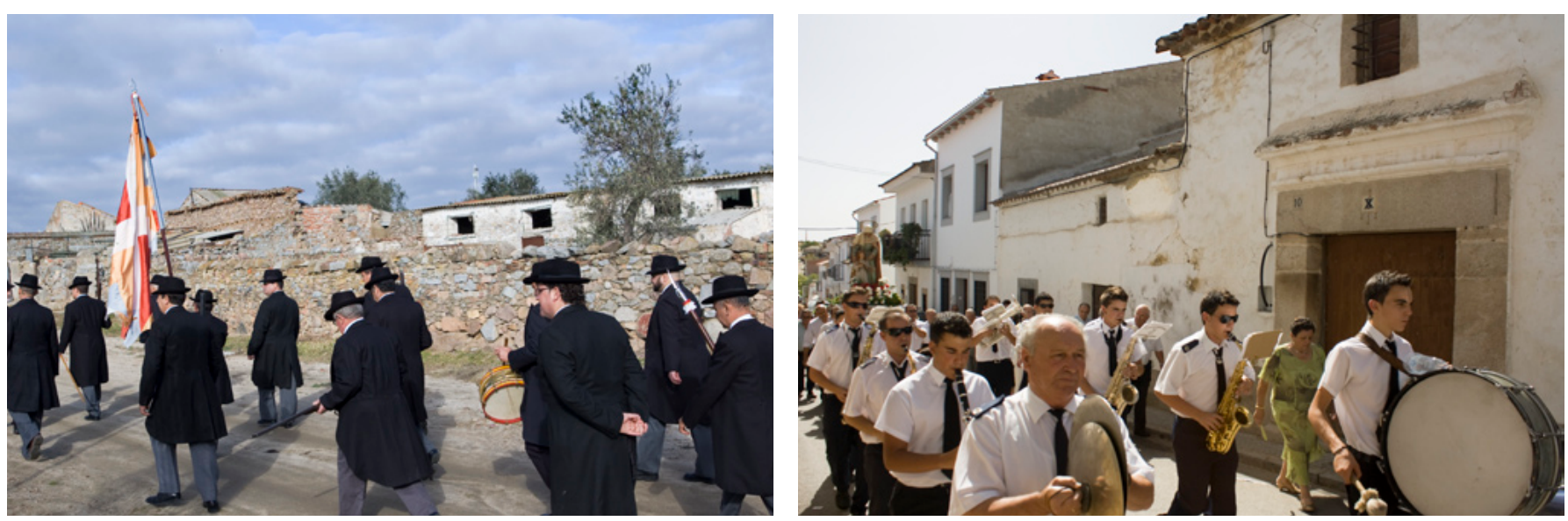


\section{Ermitas y devociones en el valle de los Pedroches}

\begin{tabular}{|c|c|c|c|c|c|c|}
\hline Población & Advocación & $E(1)$ & $\mathrm{R}(2)$ & $U(3)$ & $\mathbf{P}(4)$ & $\mathrm{R}(5)$ \\
\hline \multirow{2}{*}{ Alcaracejos } & Magdalena $(\mathrm{XVI})$ & & & & & \\
\hline & San Sebastián (XVI) & & & & & \\
\hline \multirow[t]{2}{*}{ Añora } & V. de la Peña (XVIII) & & & & & \\
\hline & San Martín (1996) & & & & & \\
\hline \multirow[t]{4}{*}{ Belalcázar } & V. de Gracia (Alcantarilla) (XV) & & & & (6) & \\
\hline & V de Consolación $(\mathrm{XVI})$ & & & & & \\
\hline & San Antón (XV) & & & & & \\
\hline & S. Sebastián (XIII) & & & & & \\
\hline \multicolumn{7}{|l|}{ Cardeña } \\
\hline Conquista & S. Gregorio (XX) & & & & & \\
\hline \multirow[t]{5}{*}{ Dos Torres } & S. Sebastián (XVI) & & & & & \\
\hline & V. de Loreto (XVI) & & & & & \\
\hline & S. Roque (XVI) & & & & & \\
\hline & S. Bartolomé (XVI) & & & & & \\
\hline & Santo Cristo de la Caridad (XVII) & & & & & \\
\hline El Guijo & V. de las Cruces (XVI) & & & & (7) & \\
\hline \multirow[t]{4}{*}{ El viso } & Santa Ana $(\mathrm{XVI} / \mathrm{XX})$ & & & & & \\
\hline & Cristo de las eras (XVI) & & & & & \\
\hline & San José (1993) & & & & & \\
\hline & V. de Vallehermoso (1990) & & & & & \\
\hline Fuente la Lancha & Santo Domingo (1999) & & & & & \\
\hline \multirow[t]{10}{*}{ Hinojosa del Duque } & V. de la Antigua (XIV) & & & & & \\
\hline & Santo Domingo (XIV) & & & & & \\
\hline & San Benito (XIV) & & & & & \\
\hline & San Isidro (XVIII) & & & & & \\
\hline & S. Gregorio (XVII) & & & & & \\
\hline & S. Sebastián (XIV) & & & & & \\
\hline & Santa Ana (XIII) & & & & & \\
\hline & Santo Cristo de las Injurias (XVIII) & & & & & \\
\hline & S. Bartolomé (XIV) & & & & & \\
\hline & V. del Castillo (XV) & & & & & \\
\hline \multirow[t]{4}{*}{ Pedroche } & V. de Piedrasantas (XVI) & & & & & \\
\hline & V. del Castillo (XVI) & & & & & \\
\hline & S. Sebastián (XV) & & & & & \\
\hline & Santa Lucía (XV) & & & & & \\
\hline \multirow[t]{4}{*}{ Pozoblanco } & V de Luna (XVI) & & & & (8) & \\
\hline & Cto de la Columna (XVIII) & & & & & \\
\hline & S. Antonio $(\mathrm{XVI})$ & & & & & \\
\hline & S. Gregorio (XVII) & & & & & \\
\hline \multirow[t]{2}{*}{ Santa Eufemia } & Santa Eufemia (XVI) & & & & & \\
\hline & Virgen de las Cruces (1898) b & & & & & \\
\hline \multirow[t]{3}{*}{ Torrecampo } & V. de Gracia (XIV) & & & & & \\
\hline & V. de las Veredas (XVI) & & & & & \\
\hline & Jesús Nazareno (XVI) & & & & & \\
\hline \multicolumn{7}{|l|}{ Villanueva de Córdoba } \\
\hline \multirow[t]{2}{*}{ Villanueva del Duque } & V. de Guía (XV) & & & & (9) & \\
\hline & San Gregorio (XVI) & & & & & \\
\hline \multirow[t]{2}{*}{ Villaralto } & Cristo de las Angustias (XVI) & & & & & \\
\hline & Santa Rita (1900) & & & & & \\
\hline
\end{tabular}

E(1) Extramuros (junto al casco urbano: cementerios, etc.);

R(2) Rural;

U(3) Urbana;

$\mathrm{P}(4)$ Devoción patronal;

$\mathrm{R}(5)$ Romería.

(6) En otros tiempos fue ermita supracomunal, a la que también acudía Hinojosa del Duque y, probablemente, la vecina población pacense de Monterrubio de la Serena.

(7) Supracomunal en el pasado. Fue ermita y devoción compartida entre el Guijo, Santa Eufemia y Torrecampo.

(8) Supracomunal. Es devoción patronal de Pozoblanco y Villanueva de Córdoba. Antaño también acudía Pedroche.

(9) Supracomunal. Acuden los pueblos de Hinojosa del duque, Fuente la Lancha, Dos Torres, Villanueva del Duque y Alcaracejos. Siendo patrona de los dos últimos. 
En este contexto habría que reseñar, por encima de lo que tienen de común estas ermitas, advocaciones y romerías con otros lugares de Andalucía, dos aspectos que sí particularizan a la comarca del valle de los Pedroches. El primero es la inusual importancia que han tenido y tienen las devociones supracomunales, reflejo de viejas prácticas de convivencia, concordias y conflictos por un territorio compartido. Así, la ermita de la Virgen de Gracia de la Alcantarilla (ubicada en un promontorio antaño fortaleza y población), hoy propiedad y albergue de la patrona de Belalcázar, fue en otros tiempos devoción compartida con Hinojosa del Duque y con la vecina población pacense de Monterrubio de la Serena; la peculiar ermita de la Virgen de las Cruces, próxima a las ruinas de una olvidada ciudad romana, hoy pertenece exclusivamente a EI Guijo, pero hasta el siglo XIX compartió con Santa Eufemia y Torrecampo santuario y devoción; la ermita de la Virgen de Luna ubicada en el corazón de antiguas tierras mancomunadas, y hoy propiedad de Pozoblanco, acoge a una imagen que sigue siendo la patrona de esta población además de la de Villanueva de Córdoba, y en el pasado también acudía a por ella Pedroche; por último, la ermita de la Virgen de Guía, hoy perteneciente a Villanueva del Duque pero ubicada en un lugar que, pese a estar en las afueras de la población, hasta el S. XIX fue territorio de Hinojosa del Duque, acoge a una imagen que continúa siendo patrona de Villanueva del Duque y Alcaracejos, pero que también cuenta con hermandades que acuden a por la Virgen en Fuente la Lancha, Dos Torres e Hinojosa del Duque.

En total once de las diecisiete poblaciones de la comarca estuvieron o siguen estando interrelacionadas entre sí a través de este complejo entramado simbólico. Pero no es sólo éste el elemento a reseñar, sino también el modo cómo se llevan a cabo estos rituales, inusual en el contexto andaluz y creo que peninsular: tanto la Virgen de Luna como la de Guía irán rotando a lo largo del año por las poblaciones que le rinden culto. Su territorio de gracia no se extiende desde el santuario que las acoge, como sería lo común, sino a partir de sí mismas en este deambular entre poblaciones.

Por último, el segundo rasgo al que nos venimos refiriendo es el peculiar sistema organizativo conformado por las hermandades militares. De forma muy sincrética, se caracterizan por la denominación militar que recibe su directiva (también suele denominarse al conjunto de la hermandad como soldadesca) constituida al menos (puede ser mucho más compleja) por un capitán, alférez y sargento, que van a portar como símbolos distintivos, respectivamente, bastón de mando, bandera y alabarda. Tampoco faltará como personaje imprescindible, vinculado al sargento, el tamborilero que irá marcando con el sonido del omnipresente tambor el proceso ritual.

A partir de estos rasgos primarios, existen otros elementos que los caracterizan, como el carácter rotativo (salvo en la Virgen de Luna de Pozoblanco) 

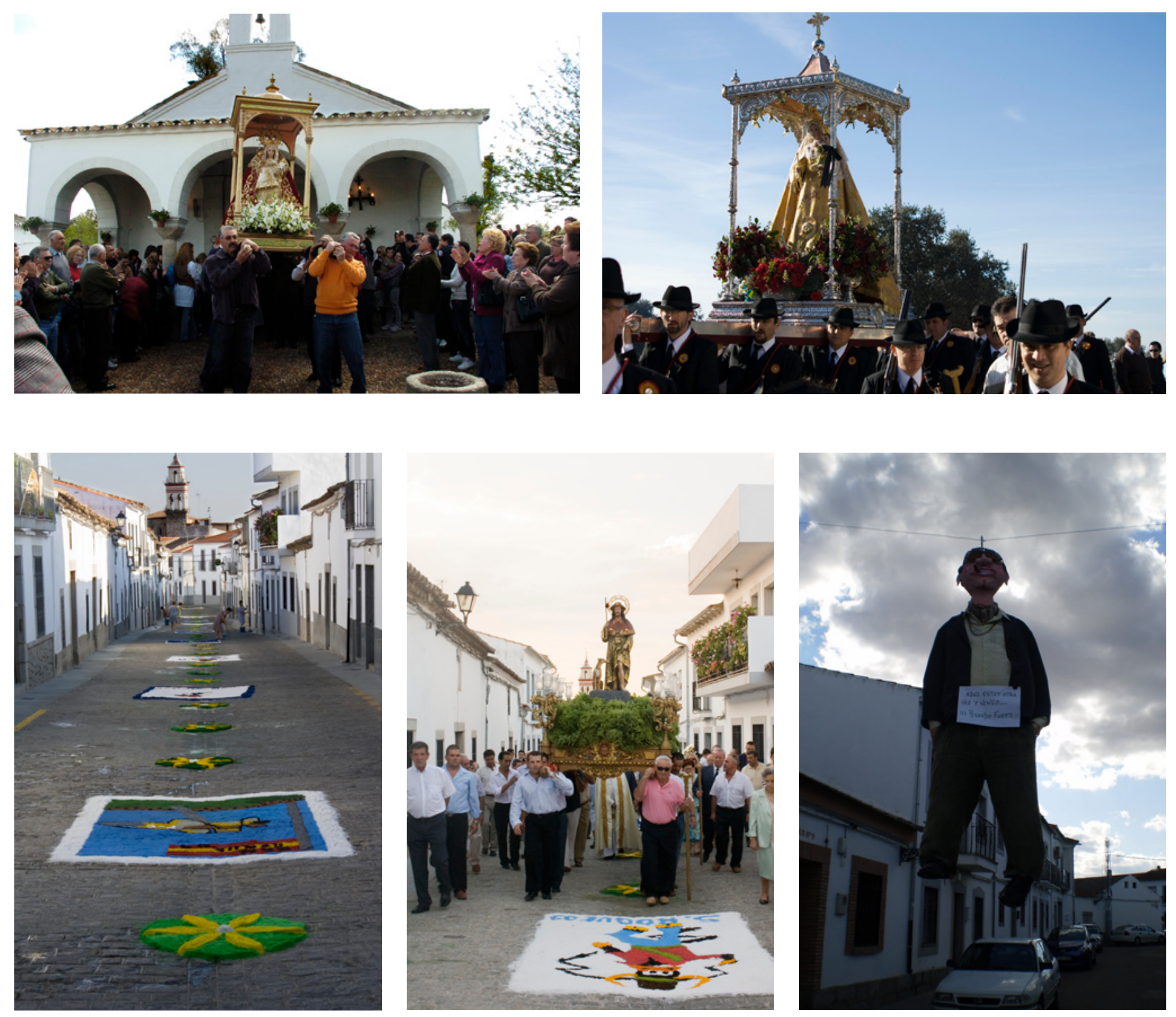

De izquierda a derecha y de arriba abajo:

Romería de la Virgen de las Cruces. El Guijo

Romería de la Virgen de Luna. Pozoblanco

de sus cargos, la importancia dada al comensalismo entre los hermanos (frecuentemente muy comedido en gastos y contenidos: garbanzos tostados, vino), y empleo de algunos de sus elementos para reseñar la vistosi-

Preparando las alfombras de San Roque dad de sus actos: revoloteo de banderas. Sobre este esquema, los matices etnográficos que particularizan cada uno de los rituales son muy variados: puede tratarse de hermandades de gloria (predominantes) o penitenciales, y en algunos casos, aun siendo penitenciales se transforman en otro momento del año en hermandades de gloria para celebrar sus actos de hermandad, como ocurre en Belalcázar, donde las cofradías de la Vera Cruz, Jesús

Procesión de San Roque. Dos Torres

| fotos Fondo Gráfico IAPH

Quema de Judas. Alcaracejos

| foto Miguel López Rísquez 
Nazareno y Cristo de la Salvación celebran sus festejos (convites, revoloteo de banderas, pasacalles) con motivo de, respectivamente, la Cruz de Mayo, el Corpus Christi y el Cristo de la Salvación.

En otras ocasiones la particularidad se encuentra en el modo como han transformado las sobrias insignias militares en floridos bastones de mando y alabardas (Santa Ana, Santa Eufemia, hermandades de Belalcázar). O bien se caracterizan por el empleo de escopetas para reseñar las diferentes fases del ritual. Y, excepcionalmente, por la extraña indumentaria, compuesta de mascota, chaleco, levita y pantalones negros, característica de las hermandades de la Virgen de Guía de Alcaracejos y Dos Torres y de Luna de Pozoblanco; complementada en los tres casos con las cartucheras y escopetas con las que realizan multitud de salvas a lo largo de los rituales. Con otro rasgo añadido más: todavía cinco de ellas (lo fueron en su mayor parte en el pasado) siguen manteniéndose como hermandades cerradas a las que sólo pueden pertenecer varones y en un número limitado.

Pero la particularidad de estos sistemas organizativos y rituales a los que dan vida no solo radica en las peculiaridades etnográficas a las que nos hemos referido, sino también en su excepcionalidad en el contexto de Andalucía. Actualmente perviven quince hermandades de esta tipología (nos consta la desaparición de al menos otras dos) actuando como base organizativa tanto de hermandades de gloria como penitenciales; $y$, dentro de éstas últimas, sosteniendo algunas de sus romerías y devociones patronales: Alcaracejos (Virgen de Guía), Villanueva de Córdoba y Pozoblanco (Virgen de Luna), Santa Eufemia (Santa Eufemia), El Viso (Santa Ana).

Fuera de esta comarca, en Andalucía, solo nos las volveremos a encontrar, en menor número, en algunas de las poblaciones de los territorios no menos limítrofes y fronterizos de las comarcas jienenses de la campiña Norte, sierra Mágina y sierra de Cazorla.

Para buscar sus orígenes, una vez más, tendríamos que seguir la senda que nos lleva hacia el norte, al corazón de las tierras castellanas. Y en este tránsito sí nos vamos a encontrar con otros ejemplos de similares características al cruzar las comarcas circunvecinas del valle manchego de la Alcudia y, en menor número, del extremeño valle de la Serena.

Pocos ejemplos como los que acabamos de describir pueden ser tan paradigmáticos a la hora de reseñar la condición de frontera cultural y, a la vez, de tierra de encuentro y paso de Andalucía que tuvo la comarca. Pero también todo lo dicho no hace sino confirmar el extraordinario patrimonio etnológico que conforma el sistema ritual y festivo del valle de los Pedroches. Un patrimonio donde pasado y presente se dan la mano cada año. 


\section{Las minas del Soldado y las Morras del Cuzna de Villanueva del Duque}

Juan Andrés Molinero Merchán | IES Los Pedroches (Pozoblanco)

URL de la contribución <www.iaph.es/revistaph/index.php/revistaph/article/view/3493>

\section{RESUMEN}

El patrimonio industrial y minero de los Pedroches constituye un elemento fundamental en la reconstrucción del pasado más remoto y reciente (siglos XIX y XX) de la comarca. En los últimos años se está procediendo a la reconstrucción material y espiritual de este legado, así como la comprensión de la contextualidad en sus elementos esenciales; también el aprovechamiento de esos vestigios desde nuevas perspectivas económicas y culturales. Las minas del Soldado y las morras de Villanueva del Duque y Alcaracejos representan un ejemplo paradigmático de arqueología minera e industrial poseedora de un rico haber, que actualmente debe entenderse ampliamente: con una mirada integral del entorno territorial, la comprensión de los fundamentos geológicos existentes y los valores paisajísticos dominantes (la dehesa). Sobre todo la conservación de un legado que nos ha dejado la historia y nos permite conocer, aunque sea por una estrecha ventana, una perspectiva económica de la comarca que fue fundamental. Tomar conciencia de ello no debe ser simplemente una gentileza cultural, sino una necesidad inminente para comprender nuestra tierra y a nosotros mismos. Todo ello desde una perspectiva de utilización racional, al tenor de una explotación económica (turística) que necesariamente debe estar vinculada a la naturaleza y sostenibilidad del medio rural.

\footnotetext{
Palabras clave

Alcaracejos (Córdoba) | Andalucía | Castillo de Cuzna | Castillos | Córdoba (Provincia) | Fortificaciones | Patrimonio Conjunto minero El Soldado | Patrimonio industrial | Valle de los Pedroches (Córdoba) | Villanueva del Duque (Córdoba) |
} 


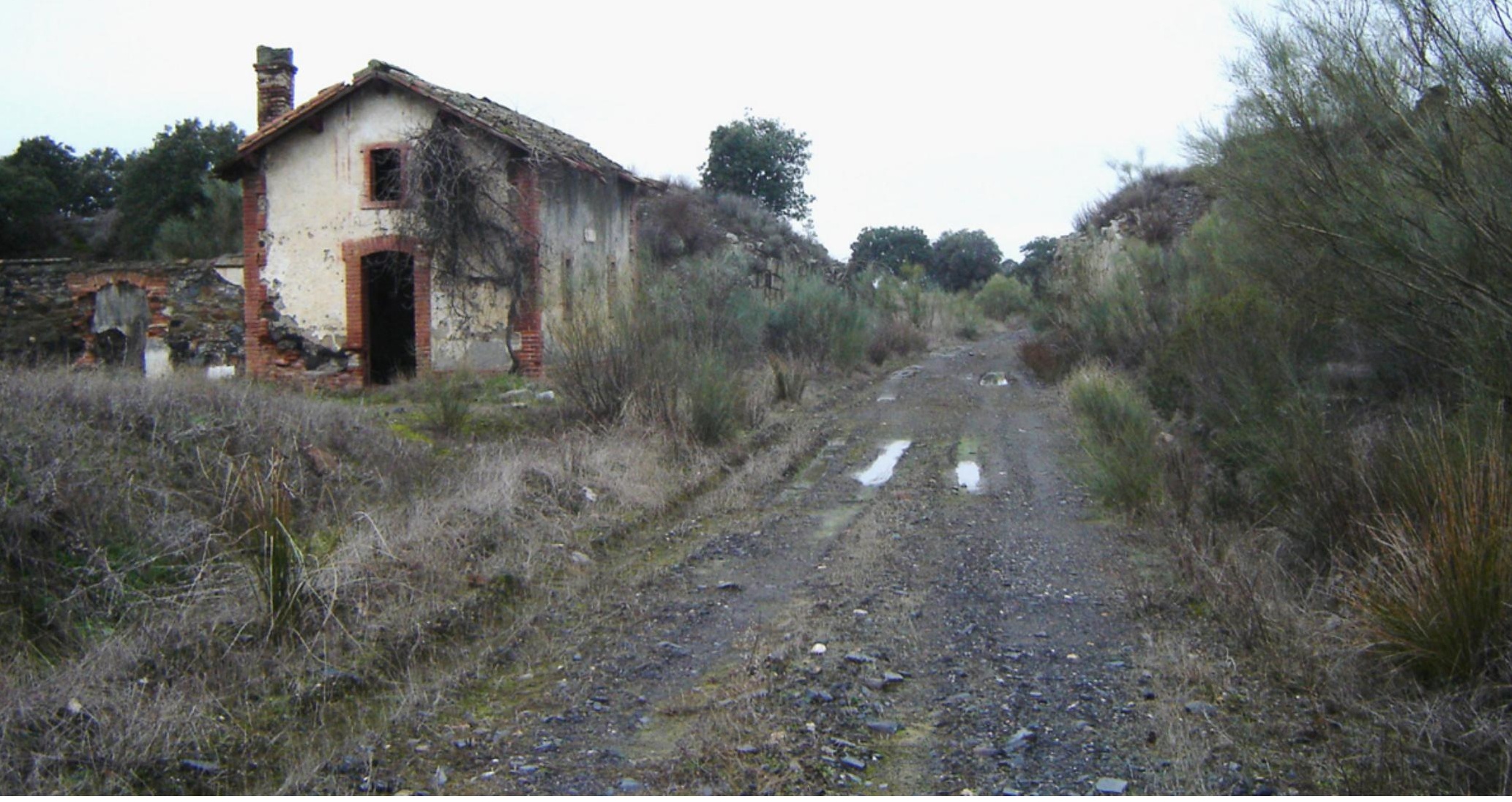

Vía verde sobre antiguo trazado del ferrocarril | foto Juan Andrés Molinero Merchán (de todas las imágenes del artículo) 
La comarca de los Pedroches es una tierra marcada en el pasado por la metalurgia. Geográficamente está muy definida por unidades exteriores que le confieren la apariencia de valle, sin serlo propiamente (VALLE, 1985), así como por una constitución geológica no carente de singularidad, que fueron determinantes para la explotación minera tradicional. Hoy día simplemente prevalece este legado minero e industrial en términos arqueológicos y museísticos, dormitando el sueño de la eternidad, con el prurito de revitalización turística y cultural. Veamos lo esencial. Entre los elementos definitorios de la configuración geológica se encuentra la presencia de un basamento granítico central, denominado Batolito de los Pedroches (CABANAS, 1968), con orientación NO-SE, bordeado de estructuras metamórficas (pizarras). Los yacimientos filonianos existentes son el resultado del flujo de los elementos metálicos residuales de la masa granítica cristalizada (JIMÉNEZ, 2005), que escapa a través de las fisuras precipitando en sus paredes las menas metálicas: acreditándose la presencia de cobre, pequeños filones de wolframio y estaño; asimismo, en el ámbito del metamorfismo, en la superficie de contacto con el granito aparecerán bismuto, cobalto y níquel, pero en zonas más alejadas se encuentran plomo, zinc y plata, que constituyen los filones más ricos de la metalurgia histórica y contemporánea (HERNANDO, 1989).

Con estos fundamentos geológicos se explica la historia minera de la comarca. Los primeros asentamientos fueron dispersos en el tiempo y en el espacio (Paleolítico, Neolítico...), con la ocupación completa del territorio a comienzos del Calcolítico y Edad de los Metales (MURILLO, 1987), así como la etapa subsiguiente prerromana (iberos y celtas), que validan el desarrollo de actividades agrarias y metalúrgicas (museo Prasa Torrecampo). La civilización romana dejó impregnada su huella de forma contundente (GARCíA ROMERO, 2002), sobre todo con restos metalúrgicos, a pesar de la precariedad del afloramiento de los legados históricos descollantes o ausencia de referencias literarias de nuestra comarca (MERINO, 2000): pues aún no han salido a flote los grandes conjuntos, como la antigua Solia, de la que desconocemos con certeza su situación, ubicándola los especialistas en las proximidades de la ermita de las Cruces del Guijo, cerro de Majadaiglesia (STYLOW, 1985). Dicho asentamiento formaba parte de la región de la Beturia habitada por los túrdulos (CORZO; JIMÉNEZ, 1980), en el convento jurídico de Cordubensis (uno de los cuatro que constituían la Bética).

Asimismo se asienta en esta demarcación territorial en época romana la población de Baedro (municipio de derecho latino), como atestiguan los vestigios arqueológicos funerarios; su emplazamiento debía estar en el ámbito occidental de la región, en el contexto geográfico de Hinojosa, Belalcázar y el Viso, aproximadamente. Entre ambas las poblaciones de Solia (al este) y Baedro (al oeste) discurría la calzada romana de Córduba-Sisapo, en una secuencia análoga a la carretera N-502 de nuestros días. La ocupación del 


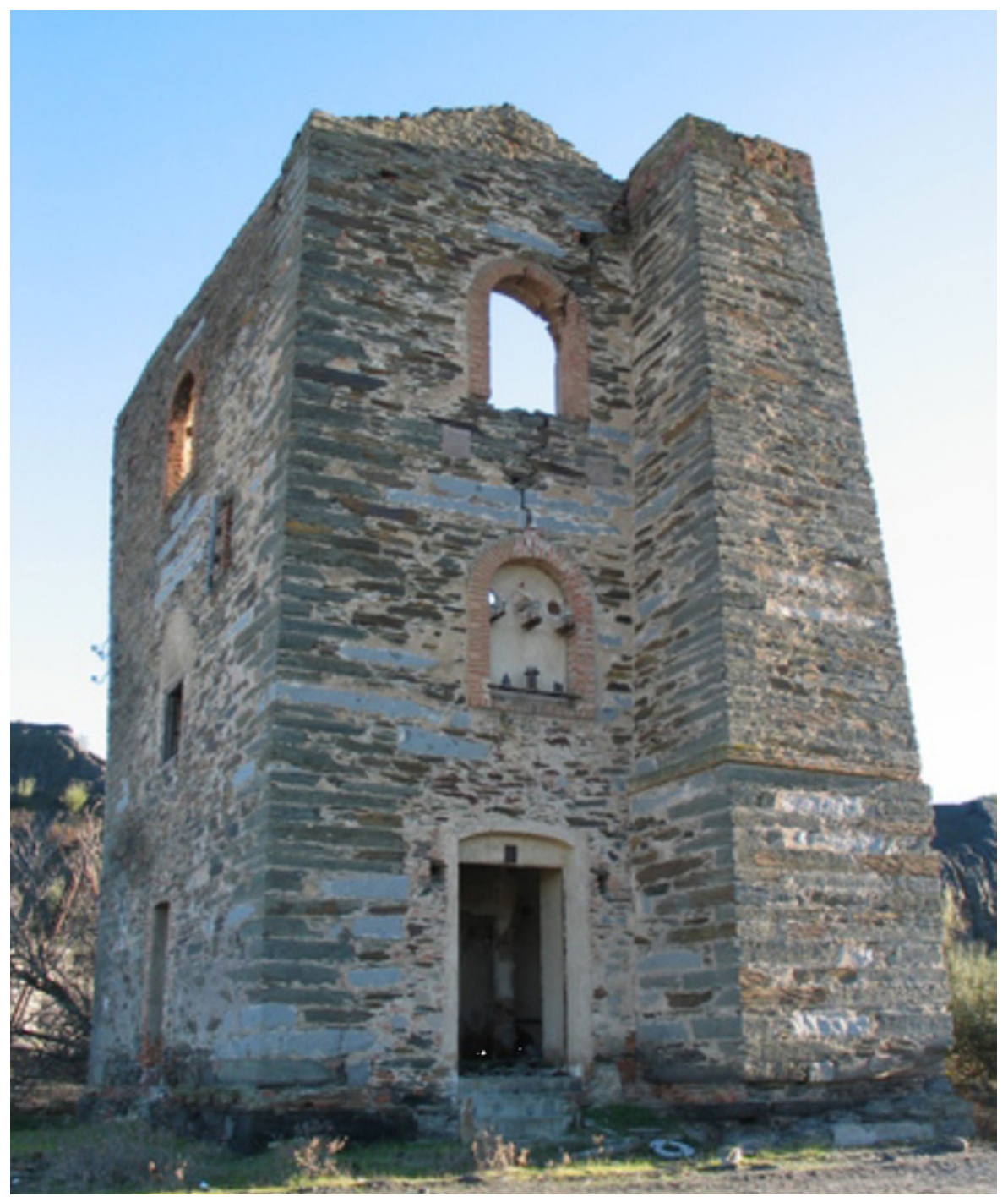

Casa de Máquinas de Mina Terreras

territorio estuvo inexorablemente unida a la explotación metalúrgica y subsiguiente comercialización con Córdoba y el Mediterráneo: a través del puerto fluvial de la colonia patricia Corduba se canalizaban los minerales de los Pedroches, e inversamente se introducían las innovaciones metalúrgicas, de cerámica, culturales, etcétera. Los vestigios arqueológicos (monedas, ornamentación de metalistería, vidrio...) acreditan no solamente la romanización y etapas subsiguientes, sino el puente que representan los Pedroches entre la meseta y el Mediterráneo, y el Atlántico a través del Guadalquivir (navegable).

Las minas del Soldado y las Morras de Villanueva del Duque y Alcaracejos constituyen un ejemplo antológico del patrimonio industrial y minero de la 


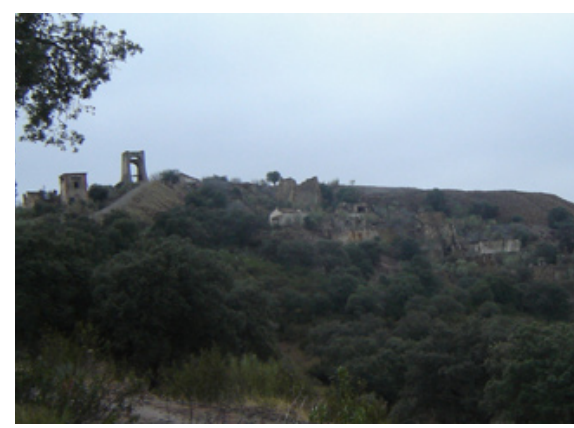

Escombreras de las Morras del Cuzna (Villanueva del Duque, Córdoba)

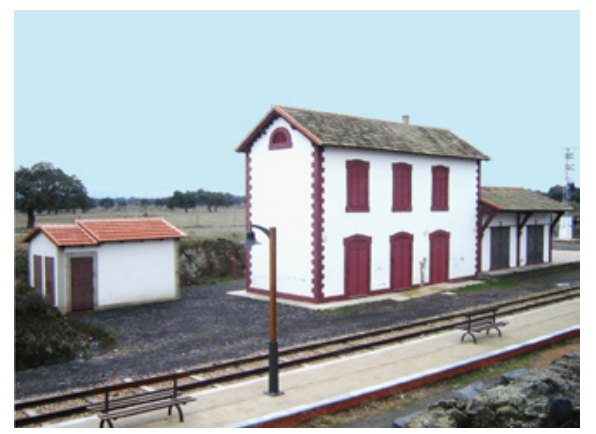

Estación de ferrocarril restaurada del Cerco (Villanueva del Duque)
Antigüedad (cobre, plomo argentífero), revitalizadas a finales del s. XIX y principios del s. XX por la Compañía Minero Metalúrgica de PueblonuevoPeñarroya, de prosapia francesa (LÓPEZ-MORELL, 2005). Las explotaciones subsiguientes, como la islámica de Al-Andalus, son herederas del emporio romano, revitalizadas con nuevos horizontes políticos; y aún en la Modernidad se intentan aprovechar los viejos recursos de siempre, como ocurre en los tiempos de señorialización (s. XVI) de Don Francisco de Zúñiga (MOLINERO, 2012), que a la sazón les dejó para su onomástica la titularidad del duque. Hoy día prevalecen los restos arqueológicos de la actividad industrial de etapa contemporánea (principios del s. XX) sobre las viejas arqueologías.

En el denominado Cerco del Soldado se puede revivir el pasado minero con las estructuras materiales (barrio Tripas con sus cuartelillos, la Subestación, el Cerco) y elementos de la actividad metalúrgica (castilletes, lavadero, casas de máquinas y bombeo, escombreras...): resulta de interés la escombrera del fino, el pozo Luisa y Pepita Norte (con más de 400 m, castillete), casa de máquinas, los vestigios de la capilla, pistas de tenis, paseos y fuentes.... En las Morras del Cuzna y entorno aparecen galerías romanas: los pozos de Carmen y Guadalupe, la casa de Máquinas de Terrera; el conjunto de la mina reservada de Pozogoitia, el balancín de pozo Aguirre y el lavadero (VALVERDE, 2000). Especial interés representa la vía estrecha de ferrocarril, cuyos retazos nos transportan en el tiempo. El Ayuntamiento de Villanueva del Duque ha restaurado con buen tino la casa de Estación para recrear el ferrocarril de la compañía (SMMP), que también cumplió un papel social importante para la población pedrocheña. Hoy día constituye un magnífico corredor como vía verde, perfectamente integrado en el entorno natural.

Con el legado del Cerco del Soldado y las Morras del Cuzna Villanueva mantiene aún muy vivo el pasado de las minas, un legado fundamental, no solamente arqueológico, sino espiritual (ROMERO, A.), que debe serlo para los Pedroches y Andalucía. Actualmente, dicho patrimonio minero e industrial se aprovecha de forma integral con la interpretación del espacio y el paisaje de la dehesa: la comprensión globalizadora del entorno (natural y minero), restauración hidrológica-forestal, dotación de servicios (albergue...), etcétera. En definitiva, nos encontramos ante un testimonio patrimonial magnífico: un conjunto de elementos naturales y culturales, materiales e inmateriales heredados del pasado donde un grupo de personas reconoce una parte importante de su identidad. Toda Andalucía debe de tomar conciencia de que la comarca de los Pedroches, vinculada actualmente a actividades primarias y su transformación, antaño tuvo un importante pasado metalúrgico. 


\section{BIBLIOGRAFÍA}

- CABANAS PAREJA, R. (1968) El macizo batolítico de Los Pedroches. Madrid: Real Academia de Ciencias Exactas, Físicas y Naturales, 1968

- CORZO, R.; JIMENEZ, A. (1980) Organización territorial de la Baetica. Revista AEspA, 53, 1980, pp. 21-48

- HERNANDO LUNA, R. (1989) Aportaciones de la minería cordobesa. Explotaciones de cobre, plomo, cinc (1850-1929). 1989, tesis doctoral (inédita)

- HERNANDO LUNA, R. (1982) La Sociedad Minera Metalúrgica de Peñarroya. Una empresa centenaria. Notas sobre sus orígenes y primeras etapas de actividad. Revista de Feria de Peñarroya-Pueblonuevo, 1982

- GARCía ROMERO, J. (2002) El papel de la minería y la metalurgia en la Córdoba romana. Córdoba: Servicio de Publicaciones, Universidad de Córdoba, 2002

- JIMÉNEZ SAN PEDRO, R. (2005) El complejo filoniano tardihercínico asociado al batolito de Los Pedroches. Bilbao: Universidad del País Vasco, 2005

- MÁRQUEZ TRIGUERO, E. (1966) Contribución al estudio metalogenético de Los Pedroches. Córdoba: IGME, 1966

- MERINO MADRID, A. (2000) Córdoba y sus pueblos en las fuentes latinas. Revista Cuzna. Revista de Investigación y Didáctica, n. ${ }^{\circ} 3$, Córdoba, 2000, pp. 115-127

- MOLINERO MERCHÁN, J. A. (2012) Villanueva del Duque. Lucha histórica por la libertad. Córdoba: Diputación Provincial de Córdoba-Ayto. Villanueva del Duque, 2012

- MURILlO, J. (1987) Poblamiento protohistórico y minería en el norte de la provincia de Córdoba. En Actas del I Coloquio de Historia Antigua de Andalucía. Córdoba: Publicaciones del Monte de Piedad y Caja de Ahorros de Córdoba, 1987

- ROMERo, M. ${ }^{a}$ A. (2010) Influencia de la minería en la sociedad villaduqueña. Boletín de la Feria de Villanueva del Duque, 2010

- STYLOW, A. V. (1985) Ordenación territorial romana en el valle de Los Pedroches (conventus cordubensis). En XVII Congreso Nacional de Arqueología, 14-16 septiembre, 1983. Zaragoza: Secretaría General de los Congresos Arqueológicos Nacionales, Universidad de Zaragoza, 1985, pp. $157-666$

- VALLE BUENESTADO, B. (1985) Geografía agraria de Los Pedroches. Córdoba: Diputación Provincial, Servicio de Publicaciones, 1985

- VAlVerde ROMERo, J. C. (2000) Estudio histórico geominero del Valle de Los Pedroches. En Informe para LEADER, 2000 (en prensa)
- LÓPEZ-MORELL, M. A. (2014) La Sociedad Minero Metalúrgica de Peñarroya: historia de una gran empresa minera. Ponencia en las IV jornadas de historia de Villanueva del Duque (25 y 26 de abril), 2014 (inédito)

- LóPEZ-MORELL, M. A. (2005) La Casa Rothschild en España (1812-1941). Madrid: Marcial Pons Historia, 2005 


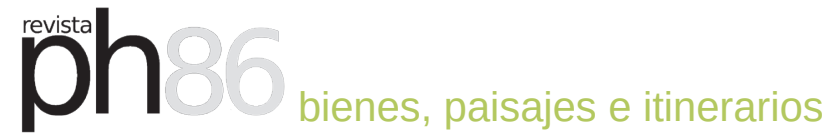

\section{Las fortalezas de Belalcázar}

Alberto León Muñoz | Dpto. de Historia del Arte, Arqueología y Música, Universidad de Córdoba

URL de la contribución <www.iaph.es/revistaph/index.php/revistaph/article/view/3508>

\section{RESUMEN}

En este texto se realiza un sucinto repaso por las principales fases constructivas detectadas en el recinto amurallado y en el castillo de Belalcázar, que presentan una secuencia de ocupación desde, al menos, el siglo IX hasta finales del siglo XV. Las estructuras conservadas constituyen una buena síntesis de la historia medieval de la comarca del valle de los Pedroches. Desde la etapa de consolidación de la dinastía omeya en un territorio periférico, pasando por su valor estratégico como fortaleza de carácter fronterizo, y la definitiva conquista castellana, hasta la conformación del señorío nobiliario a mediados del siglo $\mathrm{XV}$, todos estos episodios históricos dejaron una indeleble huella en el registro material. Sin embargo, la monumentalidad del castillo bajomedieval ha atraído todas las miradas y no en vano constituye uno de los ejemplos más conspicuos de la arquitectura defensiva medieval hispana.

\section{Palabras clave}

Andalucía | Belalcázar (Córdoba) | Castillo de Gahete | Comarca de los Pedroches | Córdoba (Provincia) | Fortificaciones | 


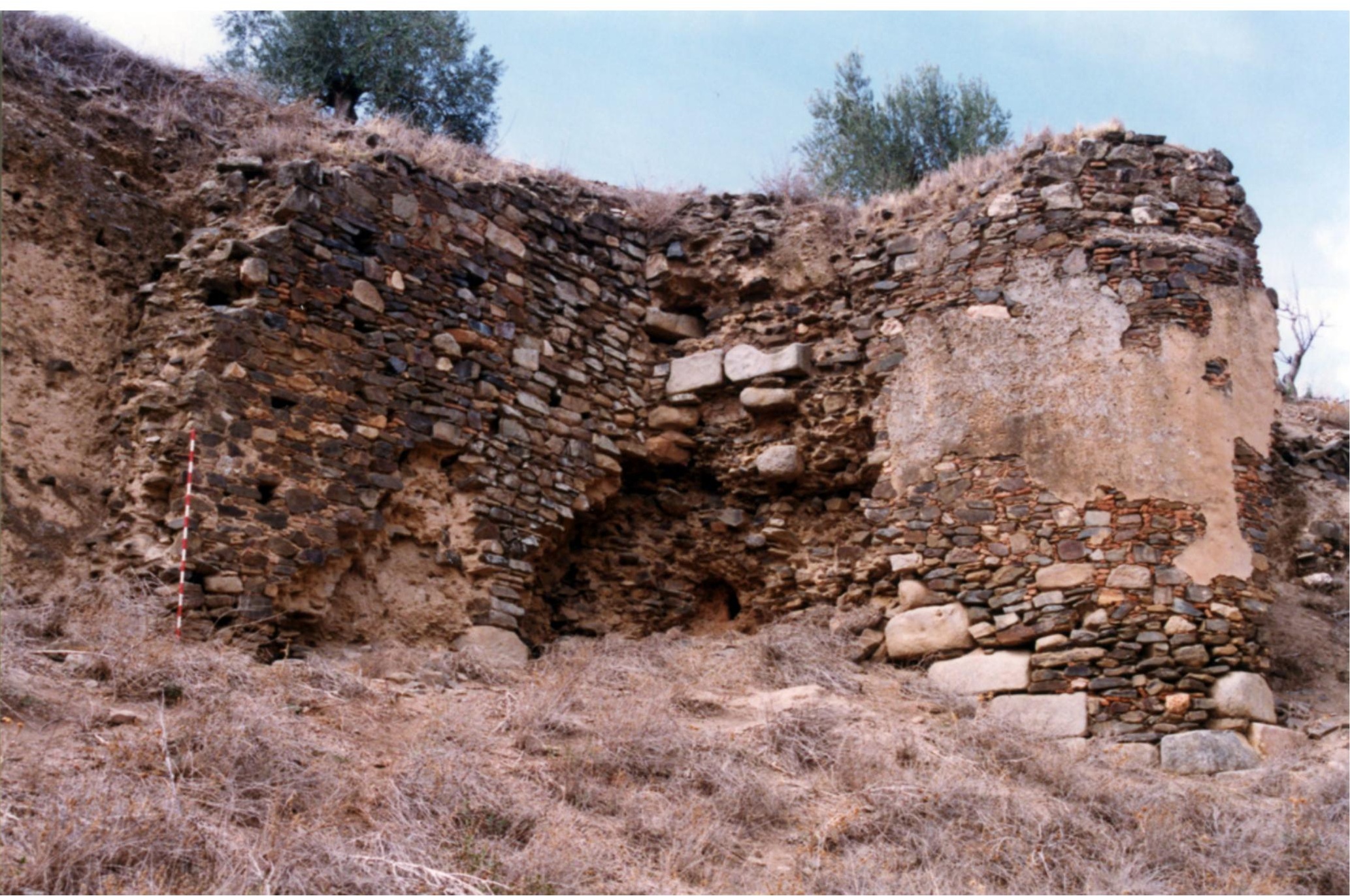

Detalle de uno de los lienzos del recinto amurallado exterior de Belalcázar. Se aprecian la reutilización de materiales constructivos romanos en una torre de probable cronología emiral y las reformas bajomedievales | foto Alberto León (de todas las imágenes del artículo) 


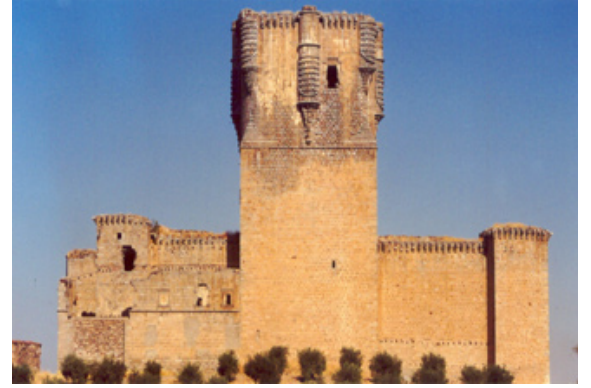

Detalle del cuerpo superior ochavado de la torre de homenaje con las escaraguaitas decoradas con el emblema de los Sotomayor
En el extremo occidental del valle de los Pedroches, en uno de los puntos a partir de los cuales la penillanura granítica cambia a una orografía algo más accidentada con un substrato geológico caracterizado por el predominio de la pizarra, se yergue, visible desde varios kilómetros de distancia, la monumental torre del homenaje del castillo de Belalcázar. El cuerpo superior ochavado de dicha mole arquitectónica, rematada en el último cuarto del siglo $\mathrm{XV}$, es el culmen de una sucesión de fortificaciones que desde el siglo IX se erigieron en este enclave. Tal es así que la historia medieval de la comarca de los Pedroches puede sintetizarse, en gran medida, en la evolución de las fortalezas de las que aún se conservan valiosísimos vestigios constructivos.

El lugar elegido para su emplazamiento fue una suave loma amesetada, que no destaca especialmente en el entorno por su altitud, pero de un especial valor estratégico, al estar rodeada en tres de sus lados por el curso del arroyo Caganchas, un excelente recurso defensivo natural. El conjunto fortificado está formado, básicamente, por dos elementos principales: el recinto exterior, en un deteriorado estado de conservación, que apenas ha sido objeto de atención, ensombrecido por la monumentalidad del segundo gran bloque, el castillo señorial de los Sotomayor. Sin embargo, ambos edificios constituyen testimonios excepcionales en el panorama andaluz en lo relativo a la arquitectura defensiva medieval.

En época emiral se fundó en este lugar una medina conocida como Gafiq, que contaba con su propia alcazaba, construida con piezas de granito reutilizadas de edificios romanos, acaso procedentes del cercano yacimiento identificado como el posible municipio de Baedro, a la manera de la alcazaba de Mérida, erigida en estas mismas fechas. En un entorno de población beréber, en la ruta de Córdoba a Mérida, la fortaleza omeya de Gafiq garantizaba el control de un extenso territorio de vital importancia para los gobernantes cordobeses.

Tras la descomposición del califato omeya cordobés, en el siglo XI esta fortaleza quedó encuadrada en un territorio fronterizo entre diferentes reinos de Taifas (Badajoz, Sevilla y Toledo), por lo que fue objeto de nuevas obras de refortificación con lienzos de mampuestos de pizarra de la zona.

Con la toma de Toledo por Alfonso VI, en 1085, se inició una etapa de inestabilidad en el territorio al sur del Tajo, como consecuencia de las esporádicas razias y campañas de saqueo de las tropas castellanas por Sierra Morena. Gafiq quedó convertida en una fortaleza que vio reducida su población, pero no su valor defensivo, pues en las fuentes islámicas destacó como una plaza ocupada por aguerridos luchadores musulmanes dedicados a practicar la yihad frente a los enemigos cristianos. Para ello reforzaron sus defensas con lienzos levantados en tapiales sobre zócalos de mampuestos, provistos de torres albarranas para la defensa de los puntos más débiles del recinto. 


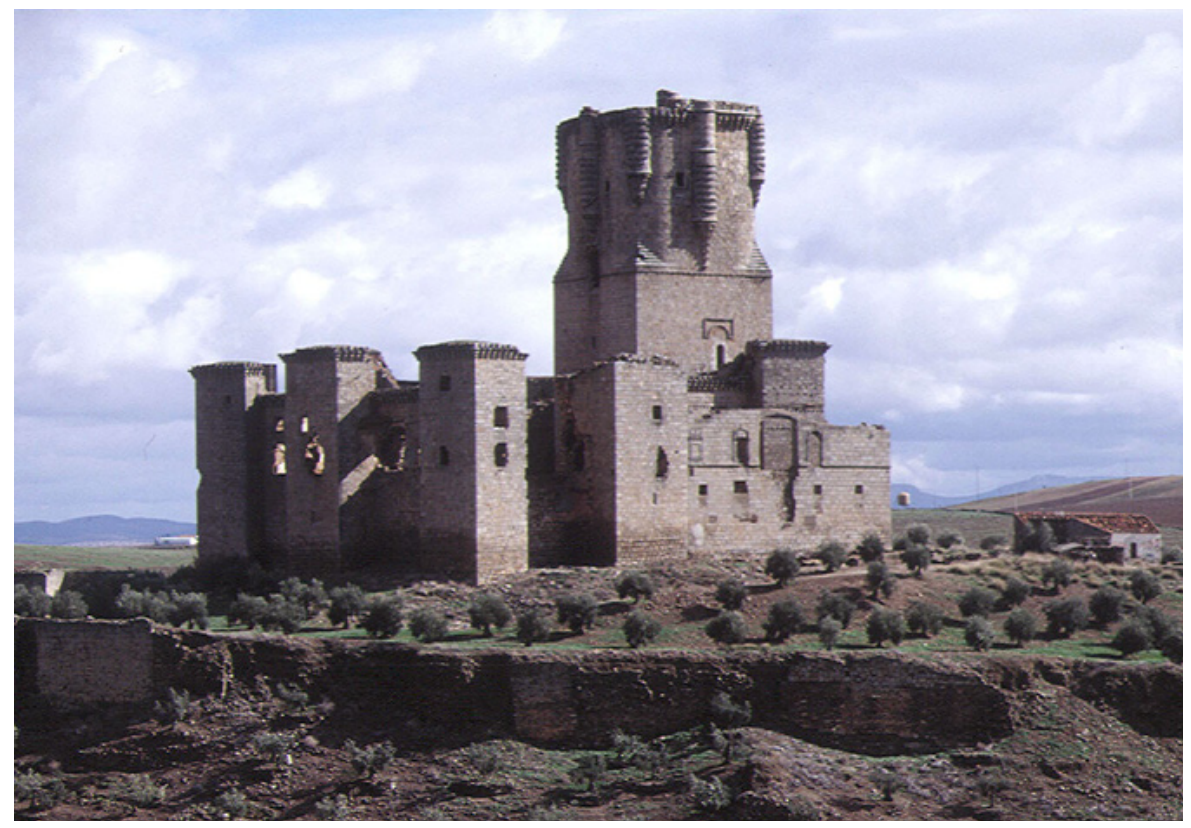

Vista general del castillo y el recinto amurallado de Belalcázar desde el suroeste

En estas condiciones se mantuvo bajo dominio almohade hasta la conquista castellana en torno a 1240.

Ya en manos cristianas, el enclave cambió su nombre por el de Gahete y fue cedido para su ocupación y repoblación al propio concejo de Córdoba. Las obras acometidas durante los siglos XIII y XIV se limitaron a la reparación de sus muros con forros de mampostería, pues pronto decayó su valor estratégico al trasladarse la frontera al sur del Guadalquivir. Sin embargo, su interés como zona de riqueza ganadera no pasó nunca desapercibida para los miembros de la nobleza urbana cordobesa, quienes se disputaron el dominio sobre sus pastos y sus rentas. Los magistrales estudios del profesor Emilio Cabrera (1977) han permitido reconstruir los diferentes intentos de usurpación de estas tierras por parte de los veinticuatros de Córdoba, una de las causas que, en el contexto de las luchas nobiliarias acaecidas a mediados del siglo XV, provocaron la cesión de Gahete, por parte de Juan II en 1444, como villa de señorío, al maestre de la orden de Alcántara, don Gutierre de Sotomayor.

Si bien tradicionalmente se ha venido atribuyendo la construcción del nuevo castillo señorial a don Gutierre, por ser el fundador del señorío, el personaje más relevante del linaje y quien acumuló la fortuna necesaria para acometer tan monumental obra, no hay ningún documento escrito que confirme esta asignación. Por otro lado, las características arquitectónicas del flamante edificio, erigido en el punto más elevado de la meseta del cerro, muestran evidentes diferencias con respecto a las otras dos fortificaciones extremeñas claramente atribuidas a su promoción: los castillos de Puebla 
de Alcocer y Herrera del Duque. En el caso que nos ocupa, el castillo consiste en un recinto de planta cuadrangular, ligeramente irregular, construido en sillería de granito, con ocho torres de flanqueo, macizas en las esquitas y huecas y habitables en el centro de los lienzos, dotado de una gran torre del homenaje cuadrada, de unos $17 \mathrm{~m}$ de lado, en su flanco oriental. Este primer edificio era tremendamente austero, sin apenas concesiones decorativas, con escasísimos huecos al exterior, tan sólo la puerta de ingreso abierta en su flanco norte, y con estrechas aspilleras y reducidas ventanas en las habitaciones superiores de las torres de flanqueo. El castillo de Belalcázar, nueva denominación adquirida a partir de este momento como consecuencia de su monumentalidad, se vincula directamente con otras construcciones extremeñas y castellanas integradas en el condado de Plasencia; en particular, con la fase inicial del castillo de Oropesa, en Toledo.

Por esta razón, parece más plausible retrasar su construcción tras la muerte del maestre de Alcántara, don Gutierre, acaecida en 1453, y adscribirla a don Alfonso de Sotomayor y su esposa, doña Elvira de Zúñiga, hija del conde de Plasencia. Este primer edificio responde a la necesidad de mantener las tierras del señorío frente a los fallidos intentos de recuperación violenta por parte de los miembros de la nobleza cordobesa.

Pero los accidentados avatares del linaje tras la repentina muerte de su titular, en 1464, provocaron que la tutoría del señorío quedara en manos de una mujer sobresaliente, doña Elvira, quien logró la consolidación del señorío gracias a una actitud prudente y sumamente inteligente.

Esta actuación se materializó en una intensa remodelación de la primitiva fortaleza que quedó transformada en un impresionante edificio de carácter palatino, dotado de un vistoso patio porticado con alfarjes ricamente ornamentados, amplios ventanales al exterior y, sobre todo, con el recrecido de los dos pisos superiores de la torre del homenaje, hasta alcanzar los $47 \mathrm{~m}$ de altura, provista de ocho escudos con el emblema de los Sotomayor labrados en las monumentales escaraguaitas.

El sutil manejo del lenguaje simbólico de la arquitectura, que encuentra en Belalcázar uno de sus más llamativos ejemplos, logró los fines para los que se planificó la fortaleza, la legitimación del linaje y la continuidad del señorío. Aún hoy, más de cuatrocientos años después, sigue causando el mismo impacto en el visitante, pese a su estado de conservación. Este sucinto recorrido evidencia, no obstante, el interés del conjunto fortificado y la necesidad de abordar un programa de intervenciones que garantice su conservación para el futuro. 


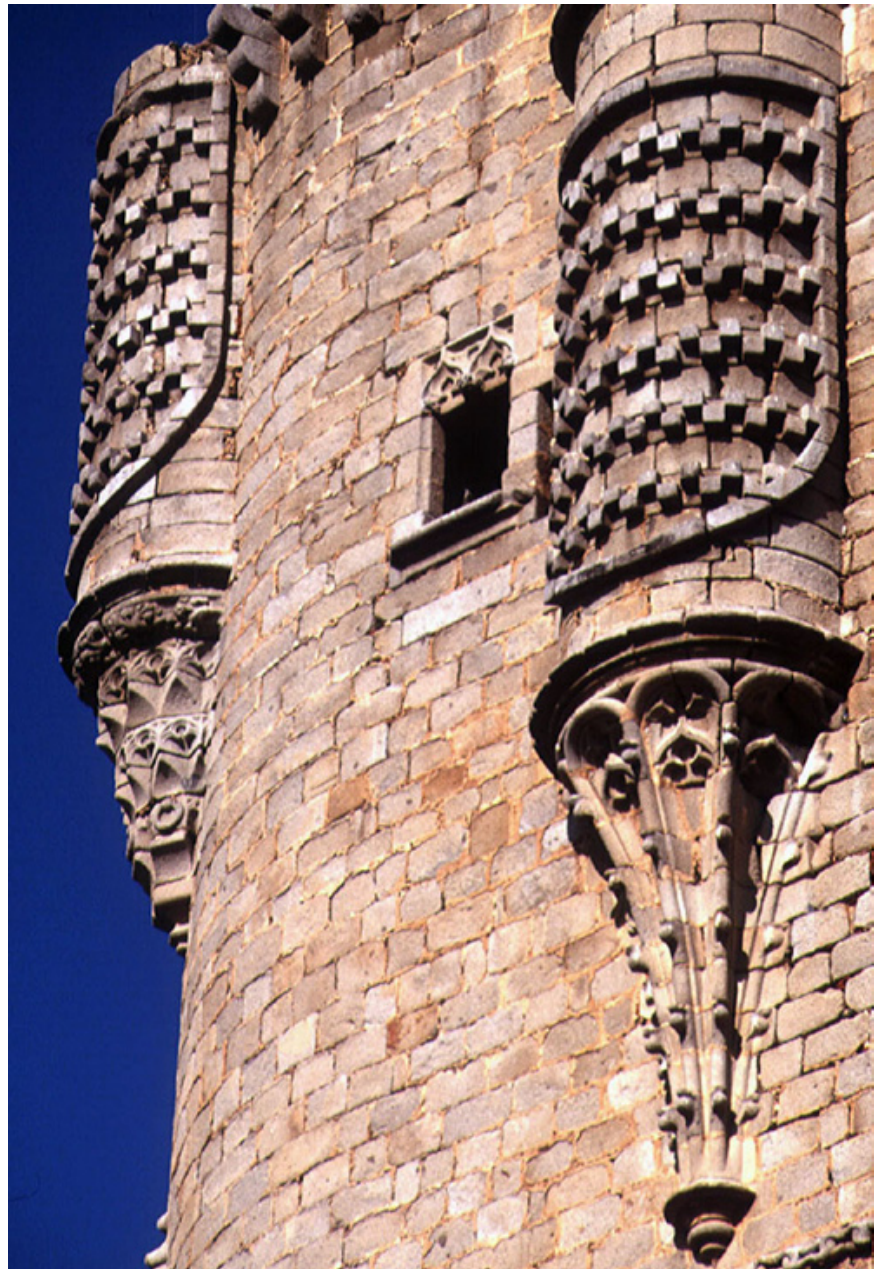

Detalle de la decoración arquitectónica de las escaraguaitas de la torre del homenaje

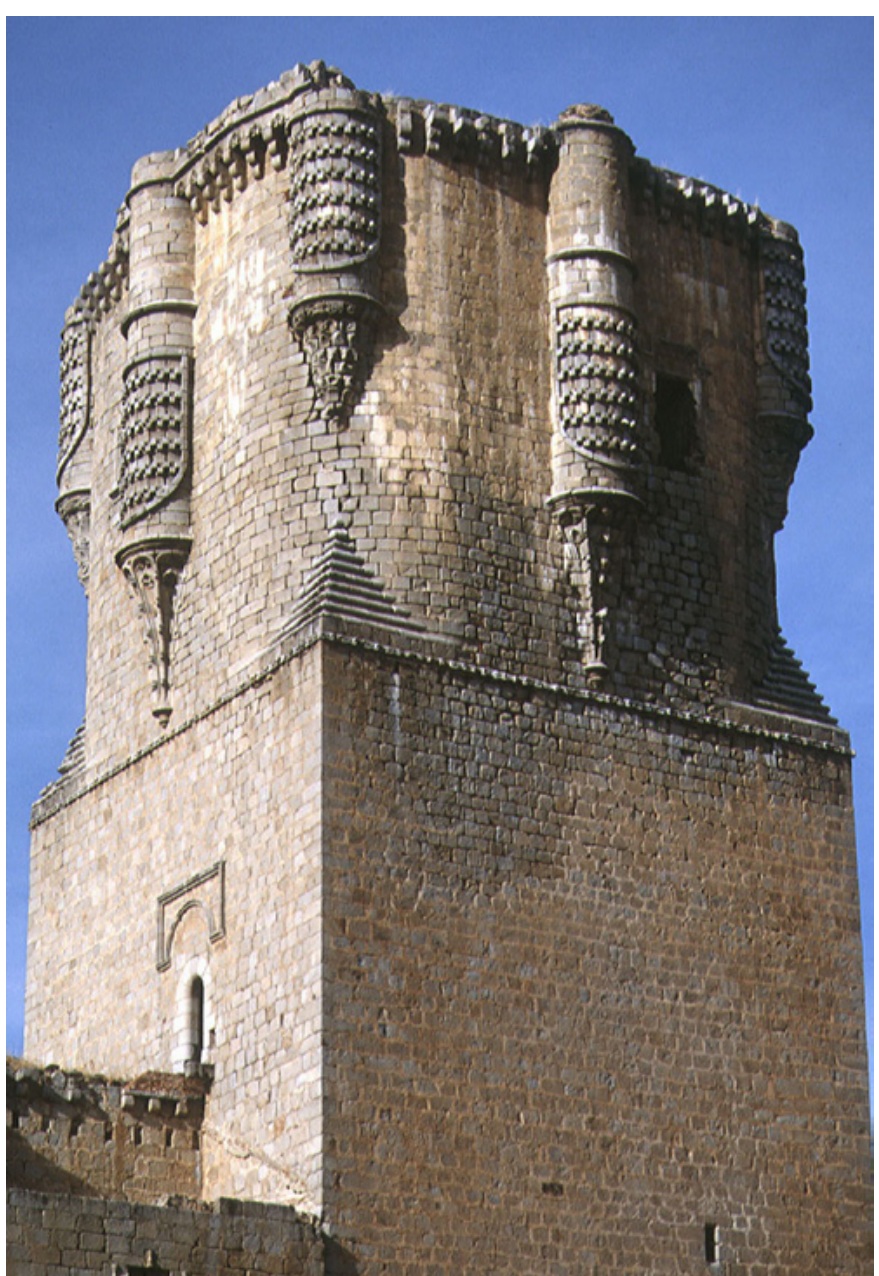

Detalle de la torre del homenaje desde su costado oriental

\section{BIBLIOGRAFÍA}

- CABRERA MUÑOZ, E. (1977) El Condado de Belalcázar (1444-1518). Aportación al estudio del régimen señorial en la Baja Edad Media. Córdoba: Monte de Piedad y Caja de Ahorros de Córdoba, 1977

- LEÓN MuÑoz, A. (2003) Las fortalezas de Belalcázar. Análisis arqueológico de su arquitectura (siglos IX-XIX). Córdoba: Diputación de Córdoba. Delegación de Cultura, 2003 